\title{
De horizontale werking van het (primaire) recht van de Europese Unie en het Belgische vermogensrecht
}

\author{
Wouter Devroe en Jules Stuyck ${ }^{*}$
}

De paragrafen 1 en 2 zijn gemeenschappelijk voor de preadviezen over Nederlands en Belgisch recht. Zij zijn geschreven door A.S. Hartkamp, met inbreng van W. Devroe en J. Stuyck.

\section{Woord vooraf}

I. Onderzoek naar de impact van Europees recht, in het bijzonder EU-recht, op privaatrecht staat in België in de kinderschoenen in vergelijking met Nederland. De preadviseurs beseffen dat de oogst aan nationale rechtspraak, zeker in vergelijking met het indrukwekkende onderzoek van collega Hartkamp, beperkt uitvalt en dat dit niet betekent dat de relevante rechtspraak ontbreekt maar veeleer dat zij die rechtspraak nog niet hebben gevonden - wat tot bescheidenheid aanzet. Momenteel wordt in Vlaanderen gelukkig gewerkt aan een breed opgezette inventarisatie, ${ }^{\mathrm{I}}$ die bestaande literatuur (met o.m. het belangrijke werk 'Invloed van het Europees recht op het Belgisch recht' uit $2003^{2}$ ) kan aanvullen. In afwachting daarvan betekent het bovenstaande wel dat de preadviseurs relatief meer aandacht besteden aan EU-recht dan aan Belgische rechtspraak. ${ }^{3}$

* Wouter Devroe is gewoon hoogleraar en vice-decaan aan de rechtsfaculteit van de K.U. Leuven en tevens hoogleraar Competition Law aan de Universiteit Maastricht en advocaat, balie van Brussel. Voorheen onder meer referendaris bij het Hof van Justitie en lid van de Belgische mededingingsautoriteit (Raad voor de Mededinging). In I999 preadviseur voor VVSRBN Sectie Publiekrecht met A. Alen ('Verzelfstandiging van bestuurstaken in België', Deventer: Tjeenk Willink). Jules Stuyck is buitengewoon hoogleraar aan de rechtsfaculteit van de K.U. Leuven en tevens buitengewoon hoogleraar aan de R.U. Nijmegen. Daarnaast is hij visiting professor European Competition Law aan de Central European University (Boedapest). Professeur invité, Université Panthéon-Assas-Paris 2. Adocaat, balie van Brussel.

I We verwijzen naar het onderzoeks- en boekproject 'De invloed van Europa op het Belgische privaatrecht', geleid door collegae V. Sagaert, I. Samoy en E. Terryn.

2 Invloed van het Europees recht op het Belgisch recht. Mechelen: Kluwer 2003, p. 846. Eveneens verplichte literatuur vormen o.m. I. Samoy, 'Hoe Europees kleurt het Belgische privaatrecht anno 20I0?', in Verbintenissenrecht. Themis, Brugge, die Keure, 2010, p. I05-130; W. van Gerven en S. Lierman, Algemeen Deel Veertig jaar later. Privaat- en publiekrecht in een meergelaagd kader van regelgeving, rechtsvorming en regeltoepassing, Beginselen van Belgisch privaatrecht I, Mechelen, Kluwer 20I0, in het bijzonder 2I-40 en Deel I, Hoofdstuk 3; P. Van Nuffel, 'Doorwerking van Europees Gemeenschapsrecht in de Belgische rechtsorde', in: J. Wouters en D. Van Eeckhoutte (red.), Doorwerking van internationaal recht in de Belgische rechtsorde, Antwerpen: Intersentia 2006, p. 337-375.

3 De preadviseurs verontschuldigen zich daarbij voor de talrijke verwijzingen naar eigen werk, die echter een functie hebben: om de tekst hier kort te houden, wordt regelmatig volstaan met een samenvatting van werk dat elders in uitgebreider vorm beschikbaar is. 
2. Er was de Nederlandse en Belgische preadviseurs veel aan gelegen om met één 'algemeen deel' naar buiten te treden. Niet alleen bespaart dit de lezer van de preadviezen tijd, maar bovenal wordt een vergelijkende discussie maar mogelijk indien zoveel mogelijk met dezelfde begrippen wordt gewerkt. Op 'punten en komma's' na is de tekst van paragrafen I en 2 hieronder dan ook identiek in het Nederlandse en het Belgische preadvies, zelfs qua formattering en citeerwijze. ${ }^{4}$ Wie deze paragrafen heeft gelezen in het Nederlandse preadvies, kan ze overslaan in het Belgische preadvies, en omgekeerd.

In dezelfde geest verwijzen wij ook in de andere paragrafen waar mogelijk naar de beschouwingen over Europees recht die collega Hartkamp in zijn preadvies maakt.

Inhoudelijk blijven er omtrent het EU-recht tussen de Nederlandse en Belgische preadviseurs slechts twee nuanceverschillen over. Om de lezer niet te dwingen er zelf naar op zoek te gaan in paragrafen I en 2, geven we ze weer in paragraaf 4.I van dit preadvies.

\section{\$ I Inleiding}

I.I Het Verdrag betreffende de Werking van Europese Unie ('VWEU'), in werking getreden op I december 2009 en opvolger van het EG-Verdrag, bevat bijna uitsluitend rechtsnormen van staats- en administratiefrechtelijke aard. Voor een belangrijk deel bestaat het verdragsregime uit voorschriften in gebods- of verbodsvorm voor het gedrag van nationale overheden. Bij de voorzieningen voor een gemeenschappelijk mededingingsregime treft men gedragsvoorschriften voor ondernemingen aan, die tot voor kort bijna uitsluitend bestuursrechtelijk werden afgedwongen. ${ }^{5}$

Slechts één verdragsbepaling is expliciet van privaatrechtelijke aard. Art. Ior lid 2 VWEU verklaart concurrentiebeperkende overeenkomsten, 'kartels', nietig.

Naar Nederlandse en Belgische opvatting bevat ook art. 340 VWEU privaatrecht. Die bepaling verplicht de Unie tot vergoeding van door haar instellingen of personeelsleden veroorzaakte schade overeenkomstig de algemene beginselen welke de rechtsstelsels der lidstaten gemeen hebben. Er zijn ook lidstaten waar deze materie - de onrechtmatige overheidsdaad - niet tot het privaatrecht wordt gerekend.

I.2 Tegen deze achtergrond is het opmerkelijk dat het Verdrag in een veel ruimere mate dan op deze twee punten ook voor het privaatrecht een belangrijke betekenis heeft gekregen. De invloed van het Unierecht op het privaatrecht is zowel via de wetgeving (infra, volgende paragraaf) als via de rechtspraak van het Hof van Justitie van de Europese Unie (hierna ook 'Hof van Justitie' of 'Hof'; infra, paragraaf I.4) gelopen.

4 Concreet betekent dit bijvoorbeeld dat we in paragrafen I en 2 geen randnummers hanteren en spreken over 'punt' in plaats van 'rechtsoverweging'.

5 P.J.G. Kapteyn en P. Verloren van Themaat, Het recht van de Europese Unie en van de Europese Gemeenschappen, Deventer: Kluwer 2003), p. 49 e.v. (Timmermans). Private afdwinging van mededingingsrecht wint nu zeer snel aan belang: infra, 5.2. 
I.3 De art. II4 en II5 VWEU verklaren de Uniewetgever bevoegd tot het vaststellen van maatregelen (richtlijnen of verordeningen) voor de onderlinge aanpassing van de wettelijke en bestuursrechtelijke maatregelen van de lidstaten die de werking van de interne markt betreffen. In andere verdragsartikelen vindt men ook meer specifieke bevoegdheidsgrondslagen. Voor dit preadvies kan met name worden verwezen naar art. I69 VWEU: het Europees Parlement en de Raad kunnen (volgens de gewone wetgevingsprocedure) ook maatregelen nemen die niet noodzakelijk betrekking hebben op de interne markt maar die het beleid van de lidstaten ter bescherming van consumenten ondersteunen, aanvullen of controleren. Van deze bevoegdheid is tot nu toe nauwelijks gebruik gemaakt.

Op basis van art. II4 VWEU (en voorheen de daarmee overeenstemmende art. 95 EG-Verdrag en ıooa EEG-Verdrag) zijn belangrijke harmonisatiemaatregelen op privaatrechtelijk gebied genomen. De meeste ervan situeren zich op het gebied van het consumentenrecht, zoals consumentenkoop, consumentenkrediet, oneerlijke bedingen, en verkoop op afstand. Enkele slechts betreffen handelsrelaties: handelsagentuur en betalingachterstand. Ook op het gebied van het vennootschapsrecht en het arbeidsrecht is in EU-verband belangrijke wetgeving tot stand gekomen. Zolang zij getrouwelijk door de wetgevers van de lidstaten in nationale wetgeving wordt omgezet, stelt deze richtlijnwetgeving de rechtstoepasser niet voor grote problemen. Vindt omzetting niet, niet correct of met overschrijding van de in de richtlijn vermelde implementatietermijn plaats, dan rust op de nationale rechters de soms moeilijke taak om het nationale recht in de zin van de richtlijn uit te leggen alsmede om te bepalen in hoeverre aan de burgers een rechtstreeks beroep jegens de overheid op de richtlijn toekomt.

I. 4 Het Hof van Justitie heeft (afgezien van de uitleg van richtlijnbepalingen) langs twee wegen in het privaatrecht ingegrepen. Enerzijds heeft het een aantal belangrijke bepalingen van het Verdrag aldus uitgelegd dat zij rechtstreeks van toepassing zijn geworden op rechtsverhoudingen tussen burgers, anders gezegd dat zij aan burgers rechten toekennen en verplichtingen opleggen jegens medeburgers. Men spreekt hier van horizontale werking van verdragsbepalingen, en wel van directe horizontale werking. Deze directe werking moet worden onderscheiden van indirecte horizontale werking. Dit laatste begrip is echter diffuus, er worden allerlei betekenissen aan toegekend. In het navolgende wordt hierop ingegaan.

De andere weg waarlangs de rechtspraak het privaatrecht beïnvloedt, is die van de algemene beginselen van Unierecht. Tot het ontwikkelen van deze beginselen heeft het Hof van Justitie zich bevoegd geacht op grond van art. I9 lid I, tweede zin VWEU, dat het Hof de opdracht geeft bij de uitleg en de toepassing van het verdrag 'de eerbiediging van het recht' te verzekeren. De beginselen hebben grotendeels een publiekrechtelijke inslag, hetgeen gelet op de sociaal-economische en bestuurlijke achtergrond van de Europese samenwerking niet verwonderlijk is. Zij dienen er in dat kader voornamelijk toe om de legaliteit van wetgeving en andere handelingen van de Unie en de lidstaten te toetsen. Maar de beginselen laten het privaatrecht niet onberoerd. In het bijzonder het effectiviteitsbeginsel - inhoudende dat aan het gemeenschapsrecht en de daarin toegekende rechten volle werking moet worden verleend is hier van groot belang gebleken. Dit beginsel oefent zijn werking op verscheidene 
wijzen uit. ${ }^{6}$ Het heeft aan de wieg gestaan van belangrijke privaatrechtelijke ontwikkelingen zoals de aansprakelijkheid van lidstaten voor handelingen in strijd met het Unierecht (Francovich-aansprakelijkheid), ${ }^{7}$ de aansprakelijkheid van particulieren voor schendingen van het kartelrecht (Courage/Crehan-aansprakelijkheid), ${ }^{8}$ en onlangs nog de erkenning van de aansprakelijkheid van de Unie krachtens ongerechtvaardigde verrijking. ${ }^{9}$ Ook aan de algemene beginselen van Unierecht komt binnen zekere grenzen directe of indirecte horizontale werking toe. ${ }^{\text {Io }}$

I.5 Gezien de aard van het Unierecht, zoals neergelegd in het VWEU, behoefde de gemiddelde civilist zich er doorgaans niet om te bekommeren. Onder de invloed van de richtlijnen is dat weliswaar veranderd, maar die problematiek is voor civilisten nog enigszins overzichtelijk, omdat richtlijnen pas gelding tussen burgers verkrijgen nadat zij zijn omgezet in een nationale wet; over het algemeen verschilt de omgang daarmee niet wezenlijk van de omgang met zuiver nationale wetgeving.

Geheel anders is de situatie geworden door de hierboven genoemde interventies van het Hof van Justitie. Rechtspraakrecht is naar zijn aard moeilijker te begrijpen en op te sporen dan in de wet neergelegd recht, en dat wordt sterker naarmate de rechterlijke uitspraken algemener van karakter zijn, in het bijzonder omdat zij toepassing geven aan open normen (zoals goede trouw, onzorgvuldigheid, openbare orde e.d.) of aan algemene rechtsbeginselen (zoals misbruik van recht, ongerechtvaardigde verrijking of non-discriminatie). Civilisten zijn uiteraard aan dit soort uitspraken van de nationale rechter gewend en kunnen de betekenis daarvan overzien voor zover de uitspraken betrekking hebben op de uitleg en ontwikkeling van het nationale privaatrecht. Maar dat is niet het geval wanneer het gaat om uitspraken op het gebied van het Europese recht, dat reeds als zodanig voor de meeste civilisten terra incognita is. Evenzeer problematisch is het wanneer algemene normen uit het economische recht zodanig worden uitgelegd en toegepast dat zij betekenis verkrijgen voor het privaatrecht. Juist dit is gebeurd met de rechtspraak van het Hof van Justitie op het gebied van de vrijverkeerbepalingen. Men denke aan recente uitspraken van het Hof waarin de mogelijkheid is erkend dat een staking in strijd is

6 Zie voor een overzicht Mr. C. Assers Handleiding tot de beoefening van het Nederlands Burgerlijk Recht, Vermogensrecht algemeen, I, Europees recht en Nederlands vermogensrecht, Deventer: Kluwer 201 I (hierna: Asser/Hartkamp 3-I^ 20II) nr. Iog e.v.

7 Zie C.H. Sieburgh, 'Het Europese gemeenschapsrecht en het Nederlandse buiten-contractuele aansprakelijkheidsrecht', in: A.S. Hartkamp, C.H. Sieburgh, L.A.D. Keus (red.), De invloed van het Europese recht op het Nederlandse privaatrecht, Deel I Algemeen Deel, Deventer: Kluwer 2007, p. 465 e.v., 486 e.v.; R. Meijer, Staatsaansprakelijkheid wegens schending van Europees gemeenschapsrecht (diss. Groningen), Deventer: Kluwer 2007.

8 Zie C.H. Sieburgh (vorige voetnoot), p. 5 I4 e.v. Deze aansprakelijkheid kan ook bestaan bij schendingen door particulieren van ander horizontaal direct werkend Unierecht. In het navolgende zullen daarvan voorbeelden worden gegeven.

9 HvJ EG I6 december 2008, Masdar/Commissie, C-47/07 P, Jurispr. 2008, p. I-976I, NJ 2009, I63 m.nt. M.R. Mok, punt 44 e.v. Zie over dit onderwerp A.S. Hartkamp, 'Ongerechtvaardigde verrijking en onverschuldigde betaling in het Europese gemeenschapsrecht', in: Hartkamp/Sieburgh/ Keus I, supra, voetnoot 7, p. 54I e.v.

Io Zie A.S. Hartkamp, 'The General Principles of EU Law and Private Law' (Zwölfte Ernst RabelVorlesung, 20I0), Rabels Zeitschrift 20II, p. 24I-259. 
met de vrijheid van vestiging of de vrijheid van dienstverlening ${ }^{\text {II }}$ of dat een door een werkgever bij sollicitaties gehanteerde regel inzake talenkennis in strijd is met de vrijheid van werknemersverkeer. ${ }^{12}$ Dergelijke vragen duiken in steeds meer situaties op. Men denke aan de bankgaranties afgegeven door het Rotterdamse havenbedrijf (strijd met de staatssteunregels?) ${ }^{\mathrm{I} 3}$ of aan de zogenoemde 'gouden aandelen' (infra, 7.I) en aan de beperking in de statuten van de vennootschap die de kerncentrale in Borssele beheert, dat de aandelen alleen in publieke handen mogen zijn (strijd met de vrijheid van kapitaalverkeer?). ${ }^{14}$

Het gaat hier om ontwikkelingen waarvan de kennis voor beoefenaars van het privaatrecht van grote betekenis is. Dit wordt nog geaccentueerd door rechtspraak van het Hof van Justitie die betrekking heeft op de verplichting van de nationale rechter om bepaalde regels van Unierecht ambtshalve toe te passen, dus zonder dat daarop door een der partijen in de procedure een beroep is gedaan. Het is niet duidelijk hoever die verplichting gaat en in welke gevallen zij bestaat. ${ }^{15}$ Gezien het grote praktische belang van deze vragen is een nauwkeurige bestudering hiervan noodzakelijk. Het probleem is dat in het Europese recht geschoolde juristen doorgaans het privaatrecht niet meester zijn en andersom. Ontwikkeling van de gecombineerde kennis van beide rechtsgebieden is dan ook dringend noodzakelijk.

I. 6 Literatuur hierover is grotendeels afwezig, zowel in Nederland als in de andere EU-lidstaten. Weliswaar zijn er thans aan verschillende universiteiten leerstoelen in het Europese privaatrecht, en worden er ook boeken over dat onderwerp geschreven, maar die gaan bijna zonder uitzondering over iets anders dan de hierboven aangestipte problematiek. Voor zover zij over geldend recht gaan, gaan zij over richtlijnen, in het bijzonder de richtlijnen op het gebied van het consumentenrecht. Maar meestal gaan zij niet over geldend recht, maar over toekomstig recht, preciezer: over recht dat niet geldt en waarvan niet zeker is of het ooit zal gelden, zoals een toekomstige codificatie in Europees verband van het algemene deel contractenrecht.

Wel publiceerde de Commissie recent de zogenoemde 'Feasibility Study', ${ }^{16}$ het werk van de door haar in 2010 aangestelde expertgroep die tot opdracht had de Commissie bij te staan in het ontwikkelen van een mogelijk toekomstig instrument inzake Europees contractenrecht. Deze studie bevat 189 artikelen op het gebied van het algemeen verbintenissenrecht met een nadruk op koopcontracten en daarmee verband houdende dienstencontracten. De expertgroep baseerde zich vooral op het

II HvJ EG II december 2007, ITWF/Viking, C-438/05, Jurispr. 2007, p. I-I0779, NJ 2008, I49 m.nt. M.R. Mok; HvJ EG I8 december 2007, Laval/Vakbonden, C-34I/05, Jurispr. 2007, p. I-II767, NJ 2008, I50 m.nt. M.R. Mok.

I2 HvJ EG 3 oktober 2000, Ferlini/Centre Hospitalier de Luxembourg, C-4II/98, Jurispr. 2000, I-808I; 6 juni 2000, Angonese/Cassa di Risparmio di Bolzano, C-28I/98, Jurispr. 2000, p. I-4I39, NJ 2000, 7IO; noot J. Stuyck in SEW 200I, p. III-II8.

I3 HR 28 mei 20I0, LJN BL4082, NJ 2010, 299 (Residex Capital IV CV/Gemeente Rotterdam).

I4 HR 2I januari 20II, LJN BO5290, RvdW 20II, I36 (Essent/Delta).

I5 Zie daarover onder meer A.S. Hartkamp, 'De verplichting tot ambtshalve toepassing van Europees recht door de Nederlandse rechter', Trema 20Io, p. I36-I43.

I6 A European contract law for consumers and businesses: Publication of the results of the feasibility study carried out by the Expert Group on European contract law for stakeholders' and legal practitioners' feedback, 3 mei 20II, http://ec.europa.eu/justice/contract. 
'Draft Common Frame of Reference' dat veel omvattender is en dat werd opgesteld door enkele groepen academici (onder leiding van C. Van Bar en H. Schulte-Nölke). Uit verklaringen van de verantwoordelijke commissaris Reding, ${ }^{17}$ kan worden afgeleid dat de Commissie denkt aan een optioneel instrument, een soort $28 \mathrm{e}$ regime dat door partijen bij grensoverschrijdende contracten zou kunnen worden gekozen in plaats van het (volgens de normale IPR-regels) toepasselijke recht van een lidstaat. De (aangepaste) tekst van de Expertgroep zou de bijlage kunnen vormen van een verordening die onder meer het toepassingsgebied van het instrument en zijn verhouding tot de IPR-regels van de Rome I- en Rome II-verordeningen zou regelen.

Over de hierboven geschetste problematiek van de directe doorwerking van Europees recht in het nationale privaatrecht bestaat zoals gezegd nog weinig literatuur. ${ }^{18}$ Daarbij verdient het volgende aandacht. Het gaat er niet alleen om te onderzoeken wat het leerstuk van de directe doorwerking van Europees recht in het privaatrecht vanuit de optiek van het Europese recht (regelgeving en rechtspraak) inhoudt, maar ook om hoe daarmee in de nationale rechtssfeer wordt omgegaan. In het in voetnoot 2 genoemde boek wordt dit voor het Nederlandse recht aan de hand van een aantal uitspraken van (vooral) de Hoge Raad onderzocht. Een dergelijk onderzoek is ook nodig voor de rechtspraak in de andere EU-lidstaten. Dat is in november 2010 erkend door het bestuur van de Vereniging voor de vergelijkende studie van het recht in België en Nederland, dat daarom voor de preadviezen 201 I dit onderwerp heeft uitgekozen. Inmiddels is besloten om een bredere Europese studie over dit onderwerp te entameren, die moet uitmonden in een Ius Commune Casebook on the Common Law of Europe. ${ }^{19}$

I.7 In de volgende paragraaf wordt ingegaan op de begrippen directe en indirecte horizontale werking. In de daarna volgende paragrafen wordt de problematiek toegespitst op de consequenties van de horizontale werking van het Unierecht voor het nationale recht, met name de wijze waarop de nationale rechter daarmee omgaat in het kader van het algemene vermogensrecht. Zie nader $\$$ 2.II. Terwijl in het preadvies over Nederlands recht de invloed van primair Unierecht op nationaal recht centraal staat, neemt in het preadvies over Belgisch recht - mede omwille van het gebrek aan (gevonden) relevante rechtspraak daarover en de professionele ervaring van de preadviseurs - secundair Unierecht een belangrijkere plaats in.

I7 Zie V. Reding in: R. Schulze en J. Stuyck (red.), Towards a European Contract Law, München: Sellier 20II, in druk.

I8 Zie het supra, in voetnoot 6 genoemde werk. Voor een beknoptere studie zie L.A.D. Keus, Europees privaatrecht, Monografieën BW A30, Deventer: Kluwer 2010.

I9 Zie www.casebooks.eu, onder 'work in progress', 'horizontal effects'. 


\section{§ 2 De begrippen directe en indirecte horizontale werking}

\section{Directe horizontale werking}

2.I Onder directe horizontale werking wordt in dit preadvies ${ }^{20}$ verstaan het geval dat een verdragsbepaling of een algemeen beginsel van Unierecht ${ }^{2 \mathrm{I}}$ rechtstreeks van invloed is op rechtsverhoudingen tussen particulieren, dat wil zeggen dat de bepaling of het beginsel leidt tot het ontstaan, de wijziging of het tenietgaan van rechten en verplichtingen in hun onderlinge verhouding. Dat kan onder meer betekenen dat wegens strijd met een verdragsbepaling een door partijen gesloten overeenkomst nietig is of een gedraging van een burger een onrechtmatige daad jegens een andere burger oplevert. Van beide volgen hierna enige voorbeelden.

Wat nietigheid betreft, zoals reeds opgemerkt spreekt het VWEU die sanctie uitdrukkelijk uit in art. Ior lid 2. In andere gevallen heeft het Hof van Justitie rechtstreekse werking in deze zin aan een verdragsbepaling gegeven. Dat is bijvoorbeeld gebeurd met art. I57 VWEU, bepalende dat iedere lidstaat ervoor zorgdraagt dat het beginsel van gelijke beloning van mannelijke en vrouwelijke werknemers voor gelijke of gelijkwaardige arbeid wordt toegepast. Het Hof besliste dat de bepaling 'dwingend recht is zodat het verbod van discriminatie niet slechts geldt voor overheidshandelingen, doch eveneens van toepassing is op alle overeenkomsten die een collectieve regeling van arbeid in loondienst inhouden, alsmede op contracten tussen particulieren. ${ }^{22}$

Het is ook gebeurd met de vrijheden van personen- en dienstenverkeer. Baanbrekend is hier geweest het arrest Walrave inzake een reglementsbepaling van de internationale Wielren Unie, die in strijd werd geacht met het vrije personenverkeer. Het Hof besliste dat 'de opheffing tussen de lidstaten van belemmeringen voor het vrije verkeer van personen en het vrij verrichten van diensten - fundamentele doelstellingen van de gemeenschap, vermeld in art. 3, sub c van het (EG) Verdrag -, in gevaar zou worden gebracht, indien de opheffing van door de staten gestelde belemmeringen kan worden ontkracht door belemmeringen voortvloeiend uit krachtens hun eigen rechtsbevoegdheid door niet onder het publiekrecht vallende verenigingen of lichamen verrichte handelingen'. ${ }^{23}$ Derhalve strekt art. 45 VWEU zich ook uit tot overeenkomsten en regelingen die niet van het openbaar gezag uitgaan, zodat,

20 Zie uitvoeriger A.S. Hartkamp, 'De werking van het EG-Verdrag in privaatrechtelijke verhoudingen. Opmerkingen over directe en indirecte horizontale werking van het primaire gemeenschapsrecht', in: Mededelingen van de Afdeling Letterkunde van de Koninklijke Akademie van Wetenschappen, Nieuwe reeks, deel 72 no. I (2009), p. 5-32; ook verschenen in WPNR 2009, 6792, p. 25I-264.

2I Zoals aangegeven, handelt het preadvies over Nederlands recht over primair Unierecht terwijl secundair Unierecht een belangrijker plaats inneemt in het preadvies over Belgisch recht. Verordeningen en richtlijnen blijven in het preadvies over Nederlands recht in beginsel buiten beschouwing. Aan verordeningen komt in beginsel directe horizontale werking toe, aan richtlijnen niet. Zie Asser/Hartkamp 3-I* 20II, nr. I56 e.v., I9I e.v. Zie over richtlijnen ook hierna \$2.6, 2.10.

22 HvJ EG 8 april ı976, Defrenne/Sabena II, 43/75, Jurispr. ı976, p. 455, NJ I976, 5 Io.

23 HvJ EG I2 december I974, Walrave en Koch/Wielerbonden, 36/74, Jurispr. I974, p. I405, punt I8; NJ I975, I48. 
naar het Hof uitdrukkelijk overwoog, ook niet-collectieve overeenkomsten tussen particulieren zijn betroffen.

Terwijl het Hof in het arrest Walrave en latere sportarresten de art. 45, 49 en 56 VWEU (vrij verkeer van werknemers, recht van vestiging en vrijheid van dienstverlening) van toepassing verklaarde op, onder meer, collectieve regelingen en later in de zaken Viking en Laval ${ }^{24}$ art. 49 (vestiging), respectievelijk art. 56 (dienstverlening) op collectieve acties (van vakbonden), bevestigde het Hof in het arrest Angonese ${ }^{25}$ dat het verbod van discriminatie op grond van nationaliteit in art. 45 (vrij verkeer van werknemers) ook in individuele privé(arbeids)relaties kan worden ingeroepen.

2.2 Er zij op gewezen dat niet steeds duidelijk is of het aan de directe horizontale werking te verbinden gevolg - in casu nietigheid van de rechtshandeling - uit het EU-recht voortvloeit of dat de vaststelling van dat gevolg aan het nationale recht wordt overgelaten. Er kan uit de rechtspraak van het Hof niet worden afgeleid welk privaatrechtelijk gevolg aan de directe werking van de bepaling van Unierecht in privaatrechtelijke rechtsverhoudingen moet worden vastgeknoopt. De nietigheid - een sanctie die naar Nederlands en Belgisch recht lijkt te moeten worden toegepast op een privaatrechtelijke regeling die in strijd is met een dwingende en inroepbare (direct werkende) bepaling van Unierecht - lijkt vanuit het Unierecht beslist een effectieve sanctie (conform het effectiviteitsbeginsel), maar ook andere (nationale) varianten van niet-afdwingbaarheid komen hiervoor in aanmerking, zo blijkt uit de EU-consumentenrichtlijnen.

Indien de vaststelling van het aan de directe werking te verbinden gevolg aan het nationale recht wordt overgelaten, vloeit naar Nederlands recht de nietigheid voort uit art. 3:40 lid 2 BW. Het Belgisch B.W. (Code Napoléon) bevat geen algemene nietigheidssanctie. Als algemene regel geldt 'pas de nullité sans texte' (zo wordt de nietigheid van een on rechtmatig beding vermeld in art. 75 \ I van de wet van 6 april 2010 betreffende marktpraktijken en consumentenbescherming). Een overeenkomst kan nietig zijn bij aanwezigheid van een wilsgebrek (dwaling, bedrog, geweld). Dan spreekt men van relatieve nietigheid. Een overeenkomst die in strijd is met een regel van openbare orde of goede zeden (art. 6 en IIo8 B.W.) is absoluut nietig. ${ }^{26}$

Of het aan strijdigheid te verbinden gevolg nu uit het EU-recht voortvloeit dan wel volgens nationaal recht moet worden vastgesteld, in beide gevallen moet van directe horizontale werking van het verdragsrecht worden gesproken.

2.3 Dat directe horizontale werking ook tot onrechtmatigheid van handelingen van burgers kan leiden, blijkt in de eerste plaats uit het arrest Courage/Crehan, ${ }^{27}$ waar het ging om een schending van art. Ior VWEU: een brouwerij verplichtte een 'gelieerde' caféhouder tot exclusieve afname van bier. In het arrest heeft het Hof de vordering tot schadevergoeding van de caféhouder tegen de brouwerij ter zake van de te hoge koopprijs van het bier erkend. Het Hof heeft de aansprakelijkheid van de

\footnotetext{
24 Zie supra, voetnoot II.

25 Supra, voetnoot 12.

26 Relatieve nietigheid kan enkel door de benadeelde worden ingeroepen, absolute nietigheid kan door eenieder worden ingeroepen, ook ambtshalve door de rechter.

27 HvJ EG 20 september 200I, Courage Ltd./Bernard Crehan, C-453/99, Jurispr. 200I, p. I-6297, NJ 2002, 43.
} 
brouwerij afgeleid uit het effectiviteitsbeginsel. De volle werking van art. IoI VWEU en in het bijzonder het nuttig effect daarvan, zou worden verminderd indien 'niet eenieder vergoeding kon vorderen van schade die hem is berokkend door een overeenkomst of een gedraging die de mededinging kan beperken of vervalsen'. In dit verband herinnerde het Hof aan de verplichting van de nationale rechter om de volle werking van het Unierecht te verzekeren en de daarin aan particulieren toegekende rechten te beschermen.

Terwijl het arrest Courage/Crehan een contractuele vordering betrof, vorderden de eisers in de zaak Manfredi (consumenten)schade die zij hadden geleden naar aanleiding van een overeenkomst (een kartel tussen verzekeraars) waarbij zij geen partij bij waren. ${ }^{28}$

De aansprakelijkheid van particulieren kan ook bestaan voor schendingen van verdragsbepalingen en andere regels met directe horizontale werking die buiten het mededingingsrecht vallen. Dit blijkt uit de uitspraken in de zaken Viking en Laval inzake geschillen tussen ondernemingen en vakbonden over de rechtmatigheid van collectieve acties. ${ }^{29}$ De ondernemingen betoogden dat deze acties onrechtmatig waren wegens inbreuk op art. 49 en 56 VWEU over de vrijheid van vestiging resp. de vrijheid van dienstverlening. Zij baseerden op deze artikelen vorderingen tot verbod en schadevergoeding. Het Hof oordeelde dat deze verdragsbepalingen ook voor een collectieve actie van vakbonden gelden en dat een zodanige actie een beperking van die vrijheden oplevert, die derhalve in beginsel is verboden. Maar de beperking kan gerechtvaardigd zijn indien zij een rechtmatig doel - bestaande in de behartiging van een algemeen belang - dient en aan het proportionaliteitsvereiste voldoet. Het stakingsrecht, dat onder meer blijkens het Europees Sociaal Handvest als een grondrecht moet worden beschouwd, kan uiteraard een zodanig rechtmatig belang dienen..$^{30}$

2.4 Directe horizontale werking kan ook andere privaatrechtelijke gevolgen dan de hierboven genoemde hebben. Zo kan een verdragsbepaling leiden tot het ontstaan van een vordering uit onverschuldigde betaling of uit ongerechtvaardigde verrijking; ofwel een verdragsbepaling kan een burger beperken in de uitoefening van absolute rechten die hij krachtens het nationale privaatrecht heeft. Het is van belang erop te wijzen dat zodra aan een bepaling directe horizontale werking is toegekend, zij in beginsel tot een verscheidenheid aan privaatrechtelijke gevolgen kan leiden. Wanneer bijvoorbeeld een arrest van het Hof aan een verdragsbepaling directe horizontale werking heeft toegekend in de context van een daarmee strijdige overeenkomst, is daarmee in beginsel gegeven dat een feitelijke handeling in strijd met die bepaling een onrechtmatige daad kan opleveren, zodat daarop een vordering tot schadevergoeding of tot verbod kan worden gebaseerd. ${ }^{3}$

28 HvJ EG I3 juli 2006, Manfredi/Lloyd Adriatico, C-295/04-298/04, Jurispr. 2006, p. I-66I9, NJ 2007, 34 m.nt. M.R. Mok. Zie hierover ook J. Stuyck in European Review of Contract Law 2005, p. 228-239.

29 Zie supra, voetnoot II.

30 Zie reeds in die zin HvJ EG I2 juni 2003, Schmidberger/Oostenrijk, C-II2/oo, Jurispr. 2003, p. $\mathrm{I}-5659$, NJ 2004, 56, AA 2003, p. 875 m.nt. K.J.M. Mortelmans, punt 74 in verband met de vrijheid van demonstratie.

3I Vgl. de zaak Courage Ltd./Bernard Crehan, supra, voetnoot 27. 
2.5 Hierboven werd vastgesteld dat directe horizontale werking gevolgen heeft voor verschillende onderdelen van het privaatrecht. Genoemd werden nietigheid van contracten, onrechtmatige daad, onverschuldigde betaling, ongerechtvaardigde verrijking, uitoefening van absolute rechten. Van andere aard is wat we 'vervolgvragen' zouden willen noemen: vragen die rijzen nadat is vastgesteld dat een bepaling van Unierecht directe horizontale werking heeft.

De eerste betreft de processuele dimensie en is bekend als de vraag van de ambtshalve toepassing. Indien een verdragsbepaling - bijvoorbeeld het kartelverbod, een discriminatieverbod of de vrijheid van werknemersverkeer - directe horizontale werking heeft, betekent dat dan dat de nationale rechter in een voor hem aanhangig geschil die bepaling ook moet toepassen indien partijen daarop geen beroep doen? Op dit vraagstuk van de ambtshalve toepassing zal later in dit preadvies worden ingegaan.

Een andere vervolgvraag betreft de uitleg-dimensie. Is de nationale rechter gehouden een rechtshandeling, in het bijzonder een overeenkomst, waarvan niet duidelijk is of de inhoud in overeenstemming is met een direct werkende bepaling van Unierecht, in overeenstemming met die bepaling uit te leggen? Het belang is evident: als de desbetreffende bepaling een daarmee strijdige rechtshandeling met nietigheid treft, is de verdragsconforme interpretatie de aangewezen weg om haar voor nietigheid te behoeden. Op dit terrein bestaat nog weinig duidelijkheid. Zelfs is onzeker of het hier wel een 'vervolgvraag' betreft: verdedigbaar (en verdedigd) is ook dat de eventuele gehoudenheid van de nationale rechter tot verdragsconforme interpretatie los staat van de vraag of het gaat om een bepaling die directe horizontale werking heeft. ${ }^{32}$

2.6 Uiteraard kan een norm die directe horizontale werking heeft - men denke bijvoorbeeld aan het reeds genoemde gelijkheidsbeginsel van art. I57 VWEU - ook werken in een rechtsverhouding tussen overheid en burger; men denke aan een arbeidsovereenkomst waarbij de werkgever een overheidsorgaan is. In de gebruikelijke Europeesrechtelijke terminologie wordt dit gebracht onder het begrip verticale (directe) werking. Dat begrip wordt namelijk in alle gevallen gebruikt waarin een burger zich tegenover de overheid op een bepaling van Unierecht kan beroepen, ook bijvoorbeeld in het geval waarin een burger zich in een geschil met zijn nationale overheid beroept op strijdigheid van een (nationale) regeling met Unierecht. Aan de desbetreffende norm (bijvoorbeeld art. I57 VWEU) kan dus tegelijkertijd directe verticale werking en directe horizontale werking toekomen. Deze terminologie kan tot verwarring leiden. Zo is de verticale werking bijvoorbeeld ook bekend in het geval van de niet geïmplementeerde richtlijn, die de burger rechten beoogt toe te kennen tegen de overheid. Het Hof van Justitie heeft aanvaard dat de overheid die een richtlijn niet, niet tijdig of niet correct implementeert daarvan niet mag profiteren, zodat de burger - mits de richtlijn zich voor directe werking leent, dat wil zeggen dat de desbetreffende bepalingen onvoorwaardelijk en voldoende nauwkeurig zijn - zich jegens de overheid op de richtlijn mag beroepen. Het omgekeerde (een beroep van

Zie daarover Asser/Hartkamp 3-I^ 20II, nr. IoI e.v., I90. 
de overheid op de richtlijn jegens de burger) mag echter niet, hetgeen wordt aangeduid met de uitdrukking dat een richtlijn geen 'omgekeerde verticale werking' kan hebben. Het is duidelijk dat dit onderscheid niet bestaat bij een regeling die directe horizontale werking heeft. Indien een regeling directe horizontale werking heeft, dat wil zeggen rechtsgevolgen teweegbrengt in een naar haar aard privaatrechtelijke verhouding, geldt dat naar beide zijden, zodat indien het gaat om een rechtsverhouding tussen overheid en burger niet slechts de burger jegens de overheid, maar ook de overheid jegens de burger een beroep op de regeling kan doen. Duidelijk is ook dat men hiertoe het begrip overheid niet behoeft op te rekken in die zin dat ook bepaalde rechtspersonen naar burgerlijk recht daaronder vallen. ${ }^{33}$ Dat is nodig indien men de desbetreffende rechtspersoon onder het bereik van de directe verticale werking wil brengen; voor de toepasselijkheid van een direct horizontaal werkende norm is de hoedanigheid van de contractspartij daarentegen niet van belang.

Indirecte horizontale werking

2.7 De term 'indirecte horizontale werking' verwijst naar gevallen waarin, zonder dat formeel directe horizontale werking wordt toegekend, rechtsgevolgen worden teweeggebracht die soortgelijk zijn aan die van directe horizontale werking.

In het navolgende worden meer in het bijzonder drie figuren behandeld die onder deze noemer vallen:

I. toepassing van een bepaling van Europees recht in privaatrechtelijke verhoudingen door middel van de 'conforme' interpretatie van nationaal recht (infra, volgende paragraaf);

2. de uit een verdragsbepaling in verbinding met art. 4 lid 3 VWEU (plicht tot loyale samenwerking) afgeleide positieve verplichting van de lidstaten om aan de verdragsbepaling effect te verlenen in horizontale verhoudingen ('positieve verplichting', infra, paragraaf 2.9); en

3. de toetsing van nationale wetgeving aan het Unierecht in een procedure tussen particulieren (infra, paragraaf 2.Io).

Uiteraard is het niet verhelderend dezelfde term voor verschillende rechtsfiguren te gebruiken. ${ }^{34}$ Hartkamp beveelt de term indirecte horizontale werking alleen in het eerstbedoelde geval aan.

2.8 Uitleg van het nationale recht ('conforme interpretatie'). Onder indirecte horizontale werking kan in de eerste plaats worden gebracht de verwezenlijking van de bepaling in privaatrechtelijke verhoudingen door middel van de interpretatie van een nationale wetsbepaling. Dit is uiteraard vooral van belang indien de desbetreffende verdragsbepaling zelf geen directe horizontale werking heeft. Is dat wel zo, dan is

33 P. Craig en G. De Búrca, EU Law. Text, Cases and Materials, Oxford: Oxford University Press 2008, p. 285 spreken hier van 'administrative direct effect'.

34 Met name de Engelstalige literatuur biedt daarvan, in overeenstemming met de weinig leerstellige denktrant van veel Engelse juristen, nog andere voorbeelden. Deze hebben in het bijzonder betrekking op effecten van richtlijnen in verhoudingen tussen particulieren. Zie Asser/Hartkamp $3^{-I^{\star}}$ 20II, nr. I58. Zie ook reeds J. Stuyck en P. Wytinck, noot bij het arrest Marleasing (infra, voetnoot 89), Common Market Law Review I99I, p. 209-2I3. 
de omweg via de interpretatie van een nationale regel strikt genomen immers overbodig. De methode is dan ook vooral opgebloeid in het kader van de omgang met bepalingen en regelingen die 'per definitie' geen directe horizontale werking hebben, zoals bepalingen van EU-richtlijnen en bepalingen van het EVRM, waarop in horizontale verhoudingen geen beroep kan worden gedaan. ${ }^{35}$

In het kader van EU-richtlijnen die niet of niet correct zijn geïmplementeerd, heet deze methode 'richtlijnconforme interpretatie'. Zij heeft daar enkele bijzonderheden wegens het feit dat lidstaten gehouden zijn richtlijnen te implementeren. In de eerste plaats zijn nationale gerechten volgens de rechtspraak van het Hof van Justitie zo enigszins mogelijk tot deze methode van interpretatie verplicht. In de tweede plaats strekt de verplichting tot richtlijnconforme interpretatie zich weliswaar in beginsel uit tot het gehele nationale recht, maar zij zal in de praktijk vaak betrekking hebben op de wet waarin de richtlijn is omgezet, dus op min of meer concrete wetsbepalingen.

Ook bij bepalingen van het VWEU laat zich deze methode hanteren. Daarbij moet vooral worden gedacht aan doorwerking van de verdragsbepaling via de open normen van het nationale recht (redelijkheid en billijkheid, maatschappelijke betamelijkheid, openbare orde, goede zeden, goed werkgeverschap, enz.). Bij het EVRM is dit procedé overbekend: het grond- of mensenrecht kan meewegen bij het oordeel of een overeenkomst die de grondrechtelijke sfeer van een partij raakt nietig is wegens strijd met de openbare orde of de goede zeden, of een beroep op een dergelijke overeenkomst naar maatstaven van redelijkheid en billijkheid onaanvaardbaar is, of een feitelijke gedraging een onrechtmatige daad oplevert, of een ontslag kennelijk onredelijk is, enzovoort. Bij bepalingen van het VWEU (of zijn voorloper, het EGVerdrag) is van deze variant van indirecte horizontale werking tot op heden althans in Nederland en België nauwelijks sprake geweest. ${ }^{6}$ Toch is zij goed denkbaar. Om één voorbeeld te noemen: de materiële bepaling inzake staatssteun (art. I07 VWEU) richt zich slechts tot de lidstaten en heeft geen directe horizontale werking. Dat betekent dat indien een onderneming staatssteun ontvangt in strijd met dat artikel, haar daardoor benadeelde concurrenten zich naar EU-recht jegens die onderneming niet op schending van art. I07 VWEU kunnen beroepen. Dat staat er echter niet aan in de weg dat de Nederlandse en Belgische rechter de gedraging van de onderneming onrechtmatig kan oordelen, indien aan de vereisten van art. 6:I62 BW resp. I382 BW is voldaan. Bij het oordeel omtrent hetgeen in het maatschappelijk verkeer betaamt, kan de rechter de schending van art. I07 VWEU in aanmerking nemen. Kán, want een verplichting tot verdragsconforme interpretatie is in deze context

35 Zie Asser/Hartkamp 3-I* 20II, nr. 226 e.v. Overigens is daarbij gebleken dat de conforme interpretatie in de praktijk niet is beperkt tot situaties waarin de verdrags- of richtlijnbepaling rechtstreekse werking ontbeert. Ook indien directe toepassing van de bepaling mogelijk is (hetgeen het geval is in 'verticale verhoudingen'), zal de rechter trachten het nationale recht verdrags- of richtlijnconform uit te leggen. Indien hij hierin slaagt, voorkomt hij immers dat hij regels van nationaal recht als strijdig met het Europese recht buiten toepassing moet laten, en behoeft hij niet de soms lastige vraag te onderzoeken of het Europese voorschrift rechtstreekse werking heeft.

Zie Asser/Hartkamp 3-I^ 20II, nr. 92 e.v. 
niet door het Hof van Justitie aanvaard. De verplichting zou zo nodig, naar analogie van het Schmidberger-arrest, ${ }^{37}$ op art. 4 lid 3 VEU kunnen worden gebaseerd. Hoe dat zij, uit de rechtspraak van het Hof blijkt dat het deze vorm van indirecte horizontale werking uitdrukkelijk open laat..$^{8}$

2.9 Positieve verplichtingen van lidstaten. Uit het VWEU kan men de verplichting voor de lidstaten afleiden om de aan de vrijverkeerbepalingen en de discriminatieverboden te ontlenen rechten te beschermen en tegenover hun burgers, ook in 'horizontale verhoudingen', te waarborgen. ${ }^{39}$ Deze constructie is bekend uit de grondrechtendogmatiek, zowel nationaal als in het kader van het Europees Verdrag voor de Rechten van de Mens (EVRM). Zij houdt in dat de nationale grondwet c.q. het EVRM aldus moet worden uitgelegd dat op de Staat niet slechts de 'negatieve' verplichting rust om zich van inbreuk op de fundamentele rechten van de burgers te onthouden, maar onder omstandigheden ook de 'positieve verplichting' om door wetgeving of andere maatregelen de uitoefening van die rechten te waarborgen, en zulks niet alleen tegenover de Staat maar ook tegenover medeburgers. Schending van die positieve verplichting kan tot aansprakelijkheid van de (verdrags)staat leiden. In het EUrecht kan een dergelijke verplichting mede op art. 4 lid 3 VEU worden gebaseerd, dat de lidstaten verplicht tot 'Unietrouw': lidstaten moeten alle algemene of bijzondere maatregelen treffen die geschikt zijn om de nakoming van het verdrag te verzekeren. Voorbeelden bieden de arresten Commissie/Frankrijk ('Spaanse aardbeien') ${ }^{40}$ en Schmidberger: ${ }^{4}$ indien wegblokkades of (andere) ordeverstoringen het vrij verkeer van goederen belemmeren waardoor particulieren worden geschaad, rust onder omstandigheden op de Staat de verplichting aan de acties een einde te maken. Dit effect van het verdragsartikel inzake het vrije goederenverkeer wordt wel 'indirecte horizontale werking' genoemd. Erg verhelderend is die uitdrukking niet. Zij wordt in het navolgende niet gebruikt.

Bij het zojuist opgemerkte wordt primair gedacht aan de uitvoerende macht van de lidstaat. Maar het begrip 'lidstaat' is ruimer en omvat alle overheidsorganen. Kan een dergelijke 'positieve verplichting' ook rusten op de rechterlijke macht? En zo ja, wat betekent dat precies? Onder het EVRM wordt de rechterlijke macht in beginsel op één lijn gesteld met andere overheidsorganen. Aan het Europese Hof voor de Rechten van de Mens in Straatsburg (EHRM) kan de vraag worden voorgelegd of een nationale wet of administratieve praktijk verenigbaar is met het EVRM en of de nationale rechter die vraag correct heeft beantwoord. Het EHRM acht zich zelfs bevoegd, zij het binnen enge grenzen, de vraag te beantwoorden of de nationale rechter in het licht van de Conventie een rechtshandeling correct heeft uitgelegd. ${ }^{42}$ De rechtsgrond hiervan is dat de rechterlijke macht evenals alle andere overheids-

37 Zie supra, voetnoot 30, punt 59.

38 Zie bijvoorbeeld HvJ EG II juli I996, SFEI/La Poste, C-39/94, Jurispr. I996, p. I-3547, punt 75.

39 Zie onder meer C. Stachel, Schutzpflichten der Mitgliedstaaten für die Grundfreiheiten des EG-Vertrags unter besonderer Berücksichtigung des Grundrechtsschutzes in der Gemeinschaft, Berlin: Duncker und Humblot 2006, besproken door M. Szydlo, C.L.M.Rev. 2008, p. I299 e.v.

40 HvJ EG 9 december 1997, Commissie/Frankrijk, C-265/95, Jurispr. I997, p. I-6959, NJ I999, 23.

4I Supra, voetnoot 30.

42 Zie Asser/Hartkamp 3-I^ 20II, nr. 233. 
instanties van een verdragsstaat de in het verdrag gewaarborgde fundamentele rechten moet verwezenlijken. Een dergelijke opvatting past in een stelsel waarin het gaat om de bescherming van rechten die aan burgers zijn verleend tegen de Staat, en die zij (in beginsel) niet tegen hun medeburgers kunnen uitoefenen. Onder het EVRM wordt deze blikrichting nog versterkt door het feit dat de procedure bij het EHRM steeds door de burger tegen de verdragsstaat wordt gevoerd en dat dit Hof aan geen van de in het EVRM geregelde rechten directe horizontale werking heeft toegekend. ${ }^{43}$

In het Unierecht is deze kwestie onzeker. Onder verwijzing naar de grondrechtenproblematiek wordt uit bepaalde arresten afgeleid dat de vraag ook in het Unierecht bevestigend moet worden beantwoord. Zo is gewezen ${ }^{44}$ op het genoemde arrest Defrenne/Sabena, ${ }^{45}$ waar het Hof van Justitie heeft overwogen dat het toenmalige art. II EEG-Verdrag (nu art. I57 VWEU) met zijn verwijzing naar 'de lidstaten' veel meer inhoudt dan een verwijzing naar de bevoegdheid van de nationale wetgever, omdat die verwijzing betrekking heeft op de uitoefening van alle overheidsfuncties die aan de toepassing van het beginsel van gelijke beloning kunnen bijdragen, waarbij het Hof ook de rechterlijke instanties op het oog heeft. Het zou echter onjuist zijn hieruit af te leiden dat het Hof hierbij doelt op een indirecte horizontale werking van het gelijkheidsbeginsel via een op het staatsorgaan rechterlijke macht rustende 'positieve verplichting'. De redenering beoogt veeleer aan te geven dat de verwijzing naar de lidstaten niet in de weg staat aan het aannemen van rechtstreekse werking van de verdragsbepaling. Zij mondt dan ook uit in de overweging (punt 37) 'dat wanneer art. II9 [nu art. I57 VWEU] van de "lidstaten" spreekt, dit mitsdien niet aldus kan worden uitgelegd, als zou rechtstreekse toepassing van het verdrag door de rechter daardoor zijn uitgesloten.' Dit moet worden gezien tegen de achtergrond van de punten 24 en 3I, waar wordt overwogen dat (het toenmalige) art. II in de omstandigheden van dit geval rechtstreeks toepasselijk is en derhalve de justitiabelen rechten verleent die de rechterlijke instanties dienen te handhaven, resp. dat de bepaling, hoewel formeel tot de lidstaten gericht, tezelfdertijd rechten verleent aan particulieren die bij de nakoming van de aldus omschreven verplichtingen belang hebben.

Aldus constateert het Hof - terecht - dat de verlening van rechten en verplichtingen aan burgers jegens elkaar voorop staat en dat, zo deze verleend zijn, de handhaving daarvan door de justitiabelen bij de rechterlijke macht kan worden gevorderd. ${ }^{46}$ De blikrichting is een fundamenteel andere dan in de grondrechtenproblematiek. Dáár gaat het om rechten die aan de burgers zijn verleend tegen de Staat, die

Zie L. Garlicki, 'Relations between Private Actors and the European Convention on Human Rights', in: A. Sajó en R. Uitz (red.), The Constitution in Private Relations: Expanding Constitutionalism, Utrecht: Eleven International Publishing 2005, p. I29 e.v.

44 A-G Poiares Maduro, conclusie voor het Viking-arrest (supra, voetnoot II), punten 39 (met noot 38) en 40.

45 Supra, voetnoot 17.

46 Ook in andere arresten wordt dat verband gelegd; zie bijvoorbeeld HvJ EG 9 maart I978, Simmenthal, Io6/77, Jurispr. I978, p. 629, punt I5 en I6; HvJ EG 20 september 200I, Courage Ltd./ Bernard Crehan, supra, voetnoot 27; HvJ EG I7 september 2002, Muñoz/Frumar, C-253/oo, Jurispr. 2002, p. I-7289, punten 27 en 28. 
daarmee 'bij extensie' de verplichting heeft gekregen om de door het grondrecht beschermde posities binnen zekere grenzen ook jegens de medeburgers te waarborgen. Daarentegen heeft het Unierecht zich mede tot een privaatrechtelijke rechtsorde ontwikkeld, waarin door het verdrag gewaarborgde rechten binnen zekere grenzen tevens in de verhouding tussen burgers gelding hebben verkregen. Voor zover dat het geval is, staat het aan de burgers zélf om die rechten te handhaven, hetgeen zij uiteraard mede via de rechter zullen doen. De 'handhaving door de rechter' staat daarmede zoals overal elders in het privaatrecht niet los van, maar in het verlengde van de aan de justitiabelen toekomende rechten. ${ }^{47}$

2.Io Rechtmatigheidstoetsing in een geding tussen particulieren. Op de lidstaten rust de verplichting om zich in overeenstemming met het Unierecht te gedragen, hetgeen onder meer impliceert dat zij geen regelingen mogen uitvaardigen en handhaven die in strijd zijn met het recht van de Unie, waaronder het VWEU. De vraag of die strijd niettemin bestaat, kan, indien de verdragsbepaling directe werking heeft, dat wil zeggen indien een burger zich erop kan beroepen, door een burger aan de rechter ter beoordeling worden voorgelegd. Dat gebeurt vaak in een geschil tussen een burger en de nationale overheid (een 'verticale verhouding'), maar het kan ook gebeuren in een geschil tussen burgers onderling (een 'horizontale verhouding'). Soms wordt in dit verband van directe horizontale werking gesproken, $4^{8}$ maar het is niet verhelderend om dit geval onder dat begrip te brengen. Weliswaar is uit processueel oogpunt sprake van een horizontale verhouding (twee burgers staan als strijdende partijen tegenover elkaar), maar aan de verdragsbepaling komt geen horizontale werking toe. Immers, indien de strijdigheid van de nationale regeling met de verdragsbepaling wordt vastgesteld, is het gevolg dat de nationale regeling niet kan worden toegepast, niet dat de verdragsbepaling de inhoud van de rechtsverhouding tussen de partijen bepaalt. Die inhoud wordt door het nationale recht of eventueel door een tussen partijen gesloten overeenkomst bepaald.

Het arrest Delhaize levert een goed voorbeeld op. 49 Een Spaanse verkoper van wijn beriep zich tegenover zijn Belgische koper op overmacht, omdat een Spaanse wettelijke regeling de export verbood. De koper sprak de verkoper aan tot nakoming en betoogde in deze procedure dat de Spaanse regeling in strijd was met art. 29 EG-Verdrag (thans art. 35 VWEU). Deze stelling bleek juist te zijn, zodat de regeling

47 Anders gezegd: de burger heeft een recht jegens zijn medeburger, en deze is verplicht jegens gene, ook los van ingrijpen door de rechter. De gedachte dat een rechter de ene burger tegen de andere beschermt zonder dat daaraan een recht van de beschermde ten grondslag ligt, is een anomalie in ons privaatrecht. Vgl. Prechal en De Vries, 'Viking/Laval en de grondslagen van het interne marktrecht', SEW 2008, p. 43I linkerkolom met voetnoot 56.

48 Zie P. Oliver en W.-H. Roth, 'The Internal Market and the Four Freedoms', CMLRev 2004, p. 407 e.v., 42I; S. Prechal en S.A. de Vries, supra, vorige voetnoot, p. 425 e.v., 43I linkerkolom. Zo leest men dikwijls dat het arrest Mangold (HvJ EG 22 november 2005, Mangold/Helm, C-I44/04, Jurispr. 2005, p. I-998I, NJ 2006, 227 m.nt. M.R. Mok) een voorbeeld is van directe horizontale werking, terwijl in dit arrest geen contractsbepaling maar een nationale wet werd getoetst aan een richtlijn en aan het gelijkheidsbeginsel (in verband met het verbod van discriminatie naar leeftijd). Zie bijvoorbeeld Editorial Comments, CMLRev 2008, p. I575; C.D. Classen, 'Freiheit und Gleichheit im öffentlichen und im privaten Recht - Unterschiede zwischen europäischem und deutschem Grundrechtsschutz?', Europarecht 2008, p. 627 e.v., 639.

HvJ EG 9 juni 1992, Delhaize/Promalvin en AGE, C-47/90, Jurispr. I992, p. I-3669, NJ I994, 588. 
niet mocht worden toegepast. De inhoud van de rechtsverhouding werd vervolgens niet door art. 35 VWEU bepaald, maar door de overeenkomst c.q. de daarop toepasselijke wet van privaatrechtelijke aard. De verkoper was ingevolge de overeenkomst tot levering gehouden. Wil men hier toch van horizontale werking spreken, dan dient 'processuele horizontale werking' van 'materiële horizontale werking' te worden onderscheiden. Inhoudelijk is dat echter zonder belang. Voor de toetsingsvraag makt het geen verschil of het om een horizontale of om een verticale verhouding gaat.

Het arrest Delhaize betrof de toetsing van een regel van (economisch) bestuursrecht aan een verdragsbepaling. Het hierboven opgemerkte geldt ook indien de toetsing plaatsvindt aan een andersoortige geschreven of ongeschreven regel van Unierecht. Daarbij kan het bij uitzondering ook om richtlijnbepalingen gaan. Zo blijkt uit de arresten CIA Security ${ }^{50}$ en Sapod Audic ${ }^{51}$ dat, ofschoon tussen burgers in beginsel geen beroep kan worden gedaan op strijdigheid van een nationale regeling met een richtlijn, ${ }^{52}$ een vergelijkbaar effect niettemin soms kan worden bereikt via hetgeen in dit verband wel wordt genoemd 'incidenteel horizontaal effect'. ${ }^{53}$ Ook in de hier bedoelde uitzonderingsgevallen geldt dat particulieren bepalingen van EU-recht wel als 'schild' tegen andere particulieren kunnen inroepen maar niet als 'zwaard': ze kunnen 'incidentele horizontale werking' wel gebruiken om bepalingen van nationaal recht buiten toepassing te laten verklaren, maar het aldus gecreëerde vacuüm in het nationale recht kunnen ze niet laten opvullen door een andere bepaling. De vraag rijst of dit onderscheid tussen richtlijnen waarop in een geschil tussen particulieren geen, en richtlijnen waarop wel een beroep kan worden gedaan, gelukkig is. ${ }^{54}$

2.II In de volgende paragrafen wordt uiteengezet wat de consequenties zijn voor het nationale privaatrecht van de horizontale werking van het Unierecht. Zoals reeds opgemerkt, staat het primaire Unierecht daarbij centraal in het preadvies over Nederlands recht, terwijl secundair Unierecht een belangrijkere plaats inneemt in het preadvies over Belgisch recht. Waar mogelijk worden zowel de directe horizontale werking als de behandelde vormen van indirecte horizontale werking belicht. Terughoudendheid wordt betracht met de supra, in nr. 2.Io besproken rechtmatigheidstoetsing van nationale wetgeving, aangezien het hier een vrij oeverloos onderwerp betreft, dat doorgaans weinig te maken heeft met het privaatrecht. Een uitzondering wordt gemaakt voor situaties waarin de band met het privaatrecht er wel is,

50 HvJ EG 30 april 1996, CIA Security International SA/Signalson SA, Securitel SPRL, C-I94/94, Jurispr. I996, I-220I.

5I HvJ EG 6 juni 2002, Sapod Audic/Eco-Emballages SA, C-I59/00, Jurispr. 2002, p. I-503I.

52 Zie de bekende arresten waarin het Hof van Justitie directe horizontale werking van richtlijnbepalingen categorisch weigert: HvJ EG 26 februari I986, Marshall/Southampton and South-West Hampshire Area Health Authority, I52/84, Jurispr. I986, p. 723; HvJ EG I4 juli I994, Paola Faccini Dori / Recreb Srl, C-91/92, Jurispr. I994, p. I-3325.

53 De terminologie komt van P. Craig en G. De Búrca, o.c., p. 296 die behalve van 'incidental horizontal effect' ook spreken over 'a limited form of horizontal effect'. Zie ook Asser/Hartkamp 3 -I* $20 \mathrm{II}, \mathrm{nr}$. I58.

54 Zie ook de annotatie door J. Stuyck van het arrest Océano Grupo (infra, voetnoot 9o) in CMLRev 20or, 733 e.v. 
zoals in gevallen waarin de aan het Europese recht getoetste regeling er een is van privaatrechtelijke aard.

Achtereenvolgens komen aan de orde het mededingingsrecht (inclusief het staatssteunrecht), de vrijverkeerbepalingen ('fundamentele vrijheden'), de verdragsbepalingen inzake discriminatie, de algemene beginselen van Unierecht en de ambtshalve toepassing. Zoveel mogelijk worden, na korte inleidende opmerkingen over de stand van het Unierecht, de horizontale rechtsgevolgen daarvan in het Nederlandse en Belgische recht geschetst op het gebied van het algemene contractenrecht, de onrechtmatige daad, de onverschuldigde betaling en de ongerechtvaardigde verrijking.

Uiteraard worden de onderwerpen uitsluitend behandeld voor zover van belang in het kader van dit preadvies. Zo wordt bij het mededingingsrecht niet ingegaan op de vereisten voor de toepasselijkheid van de art. Ior en I02 VWEU, maar op de vraag welke consequenties de toepasselijkheid van deze (direct horizonaal werkende) bepalingen heeft voor het nationale vermogensrecht, met name op het gebied van de nietigheden, de onrechtmatige daad, de onverschuldigde betaling en de ongerechtvaardigde verrijking. De vraag zal steeds zijn hoe het nationale recht (hetzij specifieke wetsbepalingen, hetzij de open normen van het nationale vermogensrecht) moet worden toegepast in gevallen die worden bestreken door direct horizontaal werkende bepalingen of beginselen van Unierecht.

\section{\$ 3 Twee benaderingen ter bestudering van de impact van Europees recht op privaatrecht}

I. We stellen vast dat de vraag naar de invloed van het Europese recht op het Belgische (of een ander nationaal) privaatrecht kan worden beantwoord op twee verschillende wijzen.

2. Zij komen hieronder aan bod in randnrs. 3-4 resp. 5-6.

3. In een eerste benadering worden gevallen opgelijst waarin toepassing wordt gemaakt van Europees recht binnen de privaatrechtelijke sfeer. Voorbeelden van vragen waaraan dan aandacht wordt besteed, zijn: Hoeveel en welke contracten - om het bij dat bij uitstek privaatrechtelijk instrument te houden - worden er omwille van Europees recht niet opgesteld (omdat het Europees recht ze verbiedt) of juist wel opgesteld (omdat nationaal recht dat ze verbiedt strijdig blijkt met Europees recht)? Hoeveel en welke contracten zien er omwille van Europees recht anders uit dan dat ze er zouden hebben uitgezien zonder dat recht, bijvoorbeeld omdat Europees recht bepaalde contractclausules verbiedt of moduleert? Hoeveel en welke (restrictieve) overeenkomsten worden opgezegd omwille van Europees recht?

Er kan dan een inventaris volgen van gevallen waarin instrumenten van privaatrecht door Europees recht zijn beïnvloed, allicht per rechtsdomein (handelsrecht, verzekeringsrecht, vennootschapsrecht enz.) en met illustraties in de vorm van bijvoorbeeld rechterlijke uitspraken of verboden clausules.

Dat de impact van Europees recht op privaatrecht volgens deze benadering enorm zal blijken, zal rechtspraktizijnen die Europees recht beheersen niet verbazen: zij 
worden zeer regelmatig geconfronteerd met vragen over de verenigbaarheid van deze of gene overeenkomst met Europees recht, of over de kansen op aansprakelijkheid wegens schending van Europees recht. Aanpassingen worden dan doorgevoerd in functie van het gegeven advies. Geen due diligence verloopt nog zonder aandacht voor EU-recht, bij grote maar ook steeds meer middelgrote en kleine ondernemingen gaat geen (distributie- of andere) overeenkomst uit zonder Europeesrechtelijk fiat.

4. De volgende gevallen kunnen de invloed van EU-recht op instrumenten van privaatrecht volgens deze eerste benadering illustreren.

- Kwantitatief ongetwijfeld een van de belangrijkste groepen van overeenkomsten die rechtstreeks, qua bewoordingen, duurtijd, contractueel vastgelegde sancties voor niet-nakoming, enzovoort de invloed ondergaan van (primair) Europees recht, in casu het mededingingsrecht, zijn de distributieovereenkomsten..$^{55}$ Niet-naleving leidt tot nietigheid en/of boetes en/of schadevergoedingsacties wat meteen bewijst dat private afdwinging van mededingingsrecht (infra, 5.2) in België nu al functioneert.

- Het Belgische algehele verbod op hypothecair krediet met variabele interestvoet bleek onhoudbaar in het licht van de EU-rechtspraak over vrij verkeer (want disproportioneel, en dus in strijd met een van de voorwaarden uit de 'rule of reason' uit het interne marktrecht). Zich hiervan bewust, stond België in 1992 als laatste lidstaat van de EU hypothecair krediet met variabele interestvoet toe, ${ }^{56}$ maar onderwierp deze kredietverlening aan voor de kredietverlener erg stringente voorwaarden (bijvoorbeeld op het vlak van referte-indexen) die sindsdien systematisch opduiken in overeenkomsten tot hypothecaire kredietverlening met consumenten die hun woonplaats in België hebben.

Zoals voorbeelden van overeenkomsten of aansprakelijkheden waarvan de inhoud of omvang rechtstreeks wordt beïnvloed door EU-recht (in het algemeen deel verwezen we naar andere voorbeelden, o.m. uit het vennootschapsrecht: supra, I.5) zijn ook voorbeelden waarbij het bestaan zelf, het wel of niet sluiten van de overeenkomst, door EU-recht wordt bepaald legio:

- Recente EU-regelgeving over economische sancties tegen een land als Syrië (of Iran, Zimbabwe, ...) bevat steeds een bepaling zoals de volgende: "Geen schadeloosstelling of enige soortgelijke vergoeding ... in verband met een overeenkomst of transactie waarvan de uitvoering, al dan niet rechtstreeks, geheel of gedeeltelijk wordt getroffen door onder dit besluit vallende maatregelen, wordt toegekend aan de ... aangewezen personen en

55 Elders maakten we hiervan een uitgebreide analyse: S. De Dier, en W. Devroe, 'Werking en einde van agentuur- en distributieovereenkomsten: mededingingsrechtelijke analyse', in: P. Naeyaert en E. Terryn (red.), Beëindiging van overeenkomsten met handelstussenpersonen, Brugge: Die Keure 2009, p. 48I-526.

56 Wet van 4 augustus 1992 op het hypothecair krediet, Belgisch Staatsblad (B.S.) I9 augustus I992. Zie hierover o.m. W. Devroe, 'De onverenigbaarheid van de nieuwe Belgische Wet op het hypothecair krediet met het E.G.-recht inzake vrije vestiging en dienstverlening', T.R.V., I993, p. 3-I4 . 
entiteiten, aan een andere persoon of entiteit in Syrië... of aan een persoon of entiteit die met behulp van of ten behoeve van de bedoelde personen en entiteiten optreedt." 57

- Momenteel geldt in België een 'Moratorium op de commercialisering van bijzonder ingewikkelde gestructureerde producten'..$^{8}$ Vooralsnog is toetreding volstrekt vrijwillig maar overwogen kan worden om dit moratorium bindend te maken op grond van wetgeving. ${ }^{59}$ Het spreekt vanzelf dat onder een dergelijk moratorium, ongeacht of het vrijwillig of bindend is, bepaalde overeenkomsten tot commercialisering van complexe financiële producten niet langer zullen worden gesloten. Sommigen betwisten echter de verenigbaarheid van minstens een bindend moratorium met EU-recht over vrij verkeer. Dat EU-recht zal desgevallend bepalen of genoemde overeenkomsten wel of niet kunnen.

- Naar Belgisch recht mogen advocaten momenteel slechts beperkt overeenkomsten sluiten met niet-advocaten. Zogenoemde 'geïntegreerde samenwerking' is volstrekt verboden, kostengroeperingen kunnen onder voorwaarden wel. ${ }^{\circ}{ }^{\circ} \mathrm{De}$ rechtsgronden voor de regeling worden rechtstreeks bepaald door EU-mededingings- en -internemarktrecht (zoals geïnterpreteerd in met name het arrest Wouters ${ }^{61}$ ). In functie van wijzigingen in dat EU-recht $t^{62}$ zullen allicht ook de modaliteiten van het verbod veranderen, en zullen wellicht overeenkomsten worden gesloten die nu niet worden gesloten, of andere overeenkomsten.

5. Een tweede benadering van de problematiek van invloed van Europees recht op nationaal privaatrecht is enger - maar wellicht slechts op het eerste zicht (zie verder). Ze gaat uit van de vaststelling dat de eerste benadering weliswaar aantoont dat het EU-recht meer of juist minder, of andere, overeenkomsten en aansprakelijkheden oplevert en aldus de wijze en frequentie beïnvloedt waarop met nationaal overeenkomsten-, aansprakelijkheids-, handels-, vennootschaps-, privaat bank- en verzekerings-, of ander privaatrecht wordt omgegaan, maar nog niet dat het EU-recht het nationale overeenkomsten-, aansprakelijkheidsrecht enzovoort zelf meer dan marginaal (bijvoorbeeld door schrapping van een verbod op een bepaald type contract) beïnvloedt. Concreet: overeenkomsten over hypothecaire kredietverlening met variabele interestvoet, distributieovereenkomsten, overeenkomsten over samenwerking

57 Art. 4bis Besluit 20II/273/GBVB van de Raad van 9 mei 20 II betreffende beperkende maatregelen tegen Syrië (Pb., L I2I/II, Io mei 20II), zoals ingevoegd door art. I, sub I), van Besluit 20II/522/ GBVB van de Raad van 2 september 20II, Pb. L 228/I6, 3 september $201 \mathrm{I}$.

58 Mededeling van de Autoriteit voor financiële diensten en markten (FSMA) van 20 juni 20II, met bijlage, beschikbaar via www.fsma.be (niet gepubliceerd in B.S.).

59 Art. $49 \S 3$ wet 2 augustus 2002 betreffende het toezicht op de financiële sector en de financiële diensten, B.S. 4 september 2002.

6o Zie bijv. art. 357-375 van de deontologische Codex 2009 van de Nederlandse Orde van Advocaten bij de balie van Brussel (de NOAB), waarin zijn verwerkt een - gedeeltelijk door het Hof van Cassatie vernietigd - Reglement van de Orde van Vlaamse Balies (OVB) van 22 januari 2003 'inzake beroepsmatige samenwerking met niet-advocaten' en een Reglement van de NOAB van 27 juni 2005 over 'Samenwerking tussen advocaten en niet-advocaten'.

6I HvJ EG Ig februari 2002, Wouters, Savelbergh en Price Waterhouse Belastingadviseurs BV/Algemene Raad van de Nederlandse Orde van Advocaten, C-309/99, Jurispr. 2002, p. I-I577.

62 Relevant is bijv. de Richtlijn 2006/I23/EG van het Europees Parlement en de Raad van I2 december 2006 betreffende diensten op de interne markt, Publicatieblad van de Europese Unie ( $\mathrm{Pb}$.) 2006, L 376, 36 (de zng. 'Dienstenrichtlijn', in werking sinds 28 december 2009), die hierover een uitdrukkelijke bepaling bevat. 
tussen advocaten en niet-advocaten, enzovoort zijn niet onderworpen aan een ander Burgerlijk Wetboek dan overeenkomsten die niet of minder door EU-recht zijn beïnvloed. Echt boeiend zou het volgens deze tweede benadering pas worden wanneer EU-recht wijzigingen aanbrengt in bijvoorbeeld het Burgerlijk Wetboek, wijzigingen die vervolgens effect zullen sorteren voor alle aan dat BW onderworpen overeenkomsten.

6. Deze tweede benadering is niet meer op dezelfde wijze per rechtsdomein geordend, bestudeert veeleer technieken van doorwerking van Europees recht en is vanuit dat perspectief allicht meer geneigd om ook uit te kijken naar toekomstige rechtsontwikkelingen zoals eenmaking van contractenrecht, ${ }^{6}$ en EU-recht over private afdwinging van mededingingsrecht (infra, 5.2). Deze benadering betoont bijzondere interesse voor:

- het aanreiken door EU-recht van nieuwe privaatrechtelijke optionele instrumenten, zoals de societas europaea $\mathrm{nu}^{64}$ of een optioneel instrument inzake contractenrecht (supra, I.6) later;

- het niet optioneel maar dwingend invoeren door EU-recht van nieuwe generieke vormen van aansprakelijkheid (vb. Francovich-en post-Francovich-aansprakelijkheid van lidstaten ${ }^{65}$, Courage- en Manfredi-aansprakelijkheid van particulieren supra, 2.3, de FIAMM-aansprakelijkheid wegens rechtmatig handelen die het Gerecht wilde invoeren maar waarvan het Hof van Justitie niet wilde weten ${ }^{66}$ ) of meer in het algemeen van nieuwe rechtsmiddelen (bijvoorbeeld 'interim relief against the Crown' in het arrest Factortame; ${ }^{67}$ 'double damages' in het Groenboek 'Schadevorderingen wegens schending van de communautaire antitrustregels ${ }^{968}$;

- een harmonisatie die op basis van haar bewoordingen kon worden opgevat als een 'minimum' harmonisatie ${ }^{69}$ maar waarvan het Hof van Justitie besliste dat ze een volledige harmonisatie beoogt (dit lijkt te gebeuren met het Europese

63 Supra, I.6. Zie op dezelfde plaats 'Contract Law. Work in Progress. Version of ig August 20II'; dit is een eerste ontwerp van de Commissie op basis van de 'Feasibility Study' en de reacties die zij naar aanleiding van de publicatie van die studie ontvangen heeft.

64 Verordening (EG) nr. 2157/200I van de Raad betreffende het statuut van de Europese vennootschap, Pb. L 294/I, Io november 200I (met bijhorende richtlijn over het statuut van werknemers).

65 Zie voor een inleiding W. van Gerven, J. Lever en P. Larouche, Cases, Materials and Text on National, Supranational and International Tort law, Oxford: Hart Publishing 2000, p. 9II-924. Verwezen wordt uiteraard naar HvJ EG 9 november 1995. Andrea Francovich/Italiaanse Republiek, C-479/93, Jurispr. I995, p. I-3843.

66 Beroepszaak met referentie naar arrest in eerste aanleg: HvJ EG 9 september 2008, Fabbrica italiana accumulatori motocarri Montecchio SpA (FIAMM) e.a./Raad en Commissie, gevoegde zaken C-I20/06 P en C-I2I/o6 P, Jurispr. 2008, p. I-65I3.

67 HvJ EG I9 juni I99o, The Queen/Secretary of State for transport, ex parte Factortame Ltd en anderen, C-213/89, Jurispr. I990, I-2433.

68 Doc. COM(2005) 672, vergezeld van een Commission Staff working paper doc. SEC(2005) I732, beschikbaar via ec.europa.eu/competition/antitrust/actionsdamages/documents.html.

69 Een 'minimum' harmonisatierichtlijn is een richtlijn dielidstaten toelaatverdergaandewettelijke bepalingen in stand te houden of in te voeren teneinde een hogere graad aan bescherming, in casu van slachtoffers van producten met gebreken, te waarborgen. Een richtlijn die maximaal of volledig harmoniseert laat de lidstaten deze vrijheid niet. 
regime inzake productaansprakelijkheid: terwijl Richtlijn 85/374/EEG ${ }^{70}$ bijzonder veel ruimte leek te laten voor nationaal recht, ${ }^{7 \mathrm{I}}$ heeft het Hof van Justitie recent bepaald dat de richtlijn maximaal harmoniseert, zodat ze veel minder vrijblijvend blijkt dan door sommigen gedacht ${ }^{72}$ );

- nog ingrijpender vormen van herschrijven van nationaal overeenkomstenrecht (onder invloed van richtlijnen consumentenbescherming), aansprakelijkheidsrecht of gerechtelijk recht ter afdwinging van dat overeenkomsten- of aansprakelijkheidsrecht (bijvoorbeeld onder invloed van een mogelijke richtlijn private afdwinging, zie verder).

7. De tweede benadering heeft met de eerste gemeen dat ook zij tot de conclusie leidt dat de invloed van Europees op nationaal privaatrecht groot is. Daarbij geldt dat de relatief punctuele, beperkte wijzigingen waartoe de EU bevoegd is, ${ }^{73}$ via een proces van spontane harmonisatie veel grotere gevolgen kunnen teweegbrengen, ook in domeinen waar de EU geen bevoegdheid heeft.

Wat Van Gerven het 'spill over' effect van Unierecht noemt, ${ }^{74}$ biedt hiervoor de verklaring. Punctueel harmoniserend EU-recht harmoniseert en versplintert tegelijk. Over de lidstaten heen worden (kleine) onderdelen van recht geharmoniseerd, maar binnen elke lidstaat wordt tegelijkertijd een wig gedreven tussen die nu geharmoniseerde onderdelen van nationaal recht enerzijds, en de niet geharmoniseerde, oorspronkelijke onderdelen anderzijds (homogeniteitsprobleem). ${ }^{75}$ Ongelijke behandeling van burgers volgt, want burgers die zich kunnen beroepen op supranationaal geharmoniseerd (contracten-, aansprakelijkheids- of ander) recht blijken veelal beter beschermd dan burgers die op het oorspronkelijke nationale recht moeten terugvallen. De 'minderbedeelden' zullen een even goede bescherming eisen, in

70 Richtlijn 85/374/EEG van de Raad van 25 juli 1985 betreffende de onderlinge aanpassing van de wettelijke en bestuursrechtelijke bepalingen der Lid-Staten inzake de aansprakelijkheid voor produkten met gebreken, $\mathrm{Pb}$. L 210/29, 7 augustus I985. $^{2}$

7 I Zie bijv. art. I3 van Richtlijn 85/374/EEG: 'Deze richtlijn laat de rechten die de gelaedeerde ontleent aan het recht inzake contractuele of buitencontractuele aansprakelijkheid of aan een op het ogenblik van de kennisgeving van deze richtlijn bestaande speciale aansprakelijkheidsregeling onverlet.' Voorts is het toepassingsgebied van de richtlijn bewust beperkt gehouden en krijgen de lidstaten tal van opties bij omzetting.

72 Zie HvJ EG 25 april 2002, María Victoria Gonzáles Sánchez/Medicina Asturiana SA, C-I83/oo, Jurispr. 2002, p. I-390I en HvJ EG Io januari 2006, Skov Æg / Bilka Lavprisvarehus A/S (en andere zaken), C-402/03, Jurispr. 2006, p. I-I99.

73 Omwille van het principe van competentie-attributie dat eraan ten grondslag ligt (de Europese Unie heeft slechts de haar in de oprichtingsverdragen uitdrukkelijk toegekende bevoegdheden) slaagt EU-recht er meestal weliswaar slechts in om erg specifieke en beperkte onderdelen van recht te harmoniseren. Zo kan EU-recht, onder voorwaarden, wel (aspecten van) consumentencontracten harmoniseren maar niet het hele contractenrecht, wel productaansprakelijkheid maar niet het hele aansprakelijkheidsrecht. De EU kan binnen het vennootschapsrecht wel de regels ter bescherming van schuldeisers harmoniseren maar niet de hele vennootschapsstructuur, binnen het fiscale recht wel de regels over BTW maar niet die over inkomstenbelastingen, enz. Dit is het rechtstreekse gevolg van de omstandigheid dat de Unie slechts over beperkte toegewezen bevoegdheden beschikt, met corresponderende beperkte verdragsrechtelijke rechtsbases.

74 Zie o.m. W. van Gerven, 'A Common Law for Europe: The Future Meeting the Past?', European Review of Private Law 200I, (485), 490-493.

75 Zie o.m. W. van Gerven, 'European Court of Justice Case Law as a Means of Unification of Private Law?', Fordham International Law Journal I996, (680), 685-686. 
rechte of politiek, en vaak ook krijgen. Gevolg daarvan is dan weer dat lidstaten dikwijls 'spontaan', buiten elke rechtsdwang vanwege de (immers niet bevoegde) EU om, niet-geharmoniseerde onderdelen van nationaal recht in lijn zullen brengen met de geharmoniseerde onderdelen.

Hierdoor reikt de impact van het supranationale recht in de praktijk nog veel verder dan het stelsel van competentie-attributie zou doen vermoeden, en dit terwijl dat recht zoals bekend reeds erg krachtig is omwille van de combinatie van de rechtstreekse werking en de suprematie ervan. Via arresten versterkt het Hof van Justitie stapsgewijze nog de rechtsbescherming van Unieburgers.

8. We spreken geen voorkeur uit voor de eerste of tweede benadering van onderzoek en kiezen, zoals de overige rechtsleer, ook niet exclusief voor het een of het ander. Om verwarring bij de studie van of het spreken over de invloed van Europees recht op nationaal privaatrecht te voorkomen, lijkt bewustzijn van het onderscheid ons echter nuttig.

\section{§ 4 Aanvullende opmerkingen over EU-recht en de impact ervan op Belgisch privaatrecht}

\section{I Over art. 345 VWEU en over indirecte horizontale werking}

9. Zoals al aangegeven, bleven na overleg over een gemeenschappelijk 'algemeen deel' tussen de Nederlandse en Belgische preadviseurs slechts nuanceverschillen bestaan. Zij lijken weinig te maken te hebben met verschillen tussen Nederlandse of Belgische rechtstraditie, maar wellicht meer met een verschil waarop vanuit het privaatrecht dan wel het EU-recht naar bepaalde leerstukken wordt gekeken.

Io. Een eerste punt betreft privaatrechtelijk relevante verdragsartikels. In paragraaf I.I geven we aan dat slechts één verdragsbepaling expliciet privaatrechtelijk van aard is (art. IoI lid 2 VWEU) terwijl naar Nederlandse en Belgische opvatting ook art. 340 VWEU privaatrecht bevat, waarbij het eerste lid van art. 340 de contractuele, en het tweede lid de buitencontractuele aansprakelijkheid van de Unie betreft.

We hadden hier graag ook art. 345 VWEU vermeld: 'De verdragen laten de regeling van het eigendomsrecht in de lidstaten onverlet.' Toegegeven, dit verdragsartikel bevat zelf geen privaatrecht; integendeel, het lijkt aan te geven dat de EU géén privaatrecht wenst te creëren om vooral niet het domein van het nationale eigendomsrecht te betreden. Relevant is o.i. echter de beperkende wijze waarop het Hof van Justitie dit artikel heeft geïnterpreteerd. Zo oordeelde het Hof dat intellectuele eigendom niet tot 'het eigendomsrecht in de lidstaten' behoort,$^{76}$ en dat art. 345 de lidstaten misschien wel de principiële vrije keuze laat tussen publieke of private eigendom (en dus de keuze tussen privatisering of nationalisering, of nog de keuze om een systeem van onteigening ten algemenen nutte in te voeren) laat maar dat de wijze waarop ze gestalte geven aan die keuze niettemin conform moet zijn met EU-

76 Vaste rechtspraak sinds HvJ EG I3 juli I995, Spanje/Raad, C-350/92, Jurispr. I995, p. I-I985. 
recht, met name mededingings- en interne marktrecht. Aan 'het fundamentele ... non-discriminatiebeginsel' kan art. 345 VWEU geen afbreuk doen. ${ }^{77}$

Met de beperkte lezing (inperking?) van de werkingssfeer van art. 345 VWEU gaat o.i. noodzakelijkerwijze een uitbreiding gepaard van de invloedssfeer van EU-recht inzake nationaal eigendomsrecht - en dat lijkt ons privaatrechtelijk relevant.

II. Een tweede punt betreft het concept 'indirecte horizontale werking'. Zoals aangegeven in de gemeenschappelijke $\$ 2$ verwijst dat concept volgens alle preadviseurs 'naar gevallen waarin, zonder dat formeel directe horizontale werking wordt toegekend, rechtsgevolgen worden teweeggebracht die soortgelijk zijn aan die van directe horizontale werking'. Europeesrechtelijk lijkt de ontwikkeling van dit concept te reconstrueren als reactie op de weigering van het Hof van Justitie om horizontale rechtstreekse werking toe te kennen aan richtlijnbepalingen. Men kan er een evolutie in zien die zelfs grotendeels samenvalt met de chronologie van de betrokken arresten: ${ }^{78}$

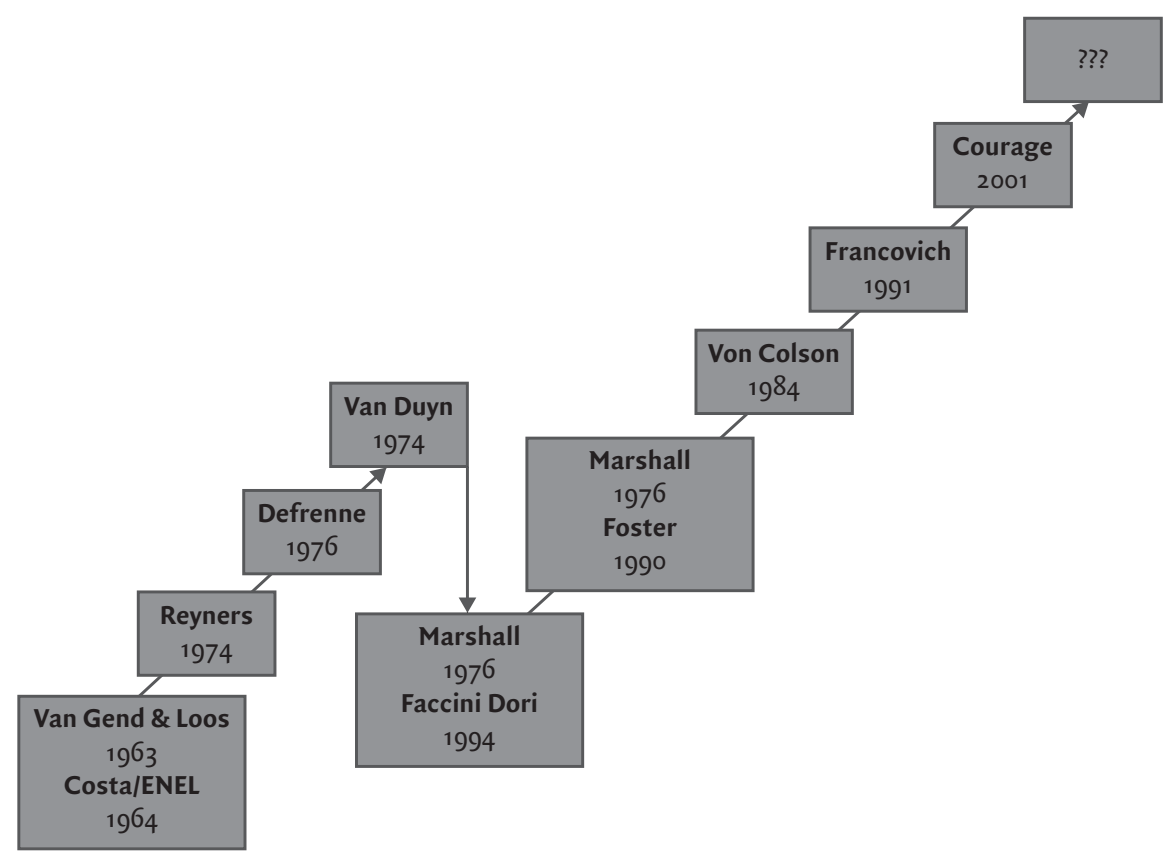

77 Vaste rechtspraak sinds HvJ EG 6 november 1984, Fearon/Irish Land Commission, I82/83, Jurispr. I984, p. 3677 , r.o. 7 .

78 Uit: W. Devroe, Rechtsvergelijking in een context van europeanisering en globalisering, Leuven; Acco 2010, p. 6r. 
Omdat eenvoud soms verhelderend werkt (en in kleiner lettertype omwille van het weinig vernieuwende karakter).

In de arresten Van Gend \& Loos en Costa|ENEL poneerde het Hof van Justitie de rechtstreekse werking (van (toen nog) EEG-recht resp. de suprematie van dat recht: een particulier kan voldoende duidelijke en onvoorwaardelijke verdragsbepalingen voor een nationale rechter inroepen en nationaal recht dat met deze bepalingen strijdt, moet buiten toepassing worden gelaten. ${ }^{79} \mathrm{Van}$ Gend \& Loos betrof verticale rechtstreekse werking van verdragsbepalingen: een onderneming riep een artikel uit het EEG-Verdrag in tegen een overheid. Vervolgens heeft het Hof rechtstreekse werking ook erkend in gevallen waarin niet één lidstaat maar alle lidstaten collectief te kort waren geschoten bij de vervulling van een verdragsrechtelijke belofte (Reyners, ${ }^{80}$ nog steeds verticale rechtstreekse werking van een verdragsbepaling) en heeft het Hof behalve verticale ook horizontale rechtstreekse werking van verdragsbepalingen erkend (Defrenne $\mathrm{II}^{{ }^{8}}$ ) en behalve verticale rechtstreekse werking van verdragsartikels ook verticale rechtstreekse werking van richtlijnbepalingen (Van Duyn ${ }^{82}$ ). Onderweg werd ook nog de rechtstreekse werking van verordeningen en beschikkingen bevestigd en, maar minder rechtlijnig, die van sommige internationale overeenkomsten. De door velen verwachte, logisch geachte, laatste stap - toekenning van horizontale rechtstreekse werking aan richtlijnbepalingen - kwam er zoals bekend evenwel niet: het Hof weigert horizontale rechtstreekse werking van richtlijnbepalingen (Marshall I, Faccini Dori ${ }^{8}{ }^{3}$ ).

Vervolgens heeft het Hof echter, (a) volgens sommigen bij wijze van 'troostprijs', vormen van rechtsbescherming ontwikkeld die (ook) als alternatief kunnen dienen voor het gebrek aan horizontale werking van richtlijnbepalingen en (b) nieuwe stappen gezet qua rechtsbescherming die duidelijk meer zijn dan een compensatie van ontbrekende horizontale werking van richtlijnbepalingen (Francovich, Courage).

I2. 'Indirecte horizontale werking' lijkt ons te verwijzen naar wat onder (a) ressorteert: het oprekken van de notie 'Staat' teneinde als verticaal voor te stellen wat anders horizontaal zou zijn en daarom niet rechtstreeks zou kunnen werken (Marshall I zelf, Foster ${ }^{8}{ }^{4}$ ); de conforme interpretatie (Von Colson en Kamann ${ }^{85}$ ); en de zogenoemde incidentele horizontale werking (CIA Security, ${ }^{86}$ dat zich op de grafiek allicht ergens tussen de arresten Von Colson en Kamann en Francovich zou situeren maar daar chronologisch niet past), alle reeds toegelicht.

Op deze drie technieken van rechtsbescherming is veel kritiek geuit, op grond van allerlei argumenten ${ }^{87}$ maar ook op grond van het argument dat het Hof via deze technieken het ver-

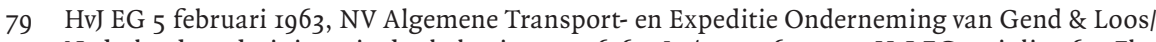
Nederlandse administratie der belastingen, 26-62, Jurispr. I963, p. 3. HvJ EG I5 juli I964, Flaminio Costa/E.N.E.L., 6-64, Jurispr. I964, p. I203.

8o HvJ EG 2I juni I974, Jean Reyners/Belgische Staat, 2-74, Jurispr. 1974, p. 63I.

8I HvJEG 8 april I976, Gabrielle Defrenne/Belgische Luchtvaartmaatschappij NV Sabena (Defrenne II), 43-75, Jurispr. I976, p. 455.

82 HvJ EG 4 december 1974, Yvonne van Duyn/Home Office, 4I-74, Jurispr. I974, p. I337.

83 HvJ EG 26 februari I986, M. H. Marshall/Southampton and South-West Hampshire Area Health Authority (Teaching), I52/84, Jurispr. I986, p. 723. HvJ EG I4 juli I994, Paola Faccini Dori/Recreb Srl, C-9I/92, Jurispr. 1994, p. I-3325.

84 HvJ EG I2 juli I990, A. Foster e.a./British Gas plc, C-I88/89, Jurispr. I99o, p. I-33I3.

85 HvJ EG Io april I984, Sabine von Colson en Elisabeth Kamann/Land Nordrhein-Westfalen, I4/83, Jurispr. I984, p. I89I.

86 Supra, voetnoot 50.

87 Tegen het oprekken van de notie 'Staat' tot overheidsbedrijven wordt bijvoorbeeld terecht aangevoerd dat het niet van het publiek of privaat aandeelhouderschap van een onderneming kan 
schil met 'echt' horizontaal effect van richtlijnbepalingen zo klein maakt dat het Hof maar beter 'echte' horizontale rechtstreekse werking zou toekennen aan richtlijnbepalingen, om zo een einde te maken aan de huidige verwarring en rechtsonzekerheid.

De scheidingslijn tussen toekenning en weigering van horizontale rechtstreekse werking voor richtlijnbepalingen, wordt in bepaalde gevallen van met name conforme interpretatie en incidentele horizontale werking inderdaad erg dun. Het enige werkzame onderscheid dat overblijft, lijkt - we citeren § I - dat particulieren in deze gevallen "de richtlijn wel als "schild" tegen andere particulieren kunnen inroepen maar niet als "zwaard": ze kunnen "incidentele horizontale werking” wel gebruiken om bepalingen van nationaal recht buiten toepassing te laten verklaren, maar het aldus gecreëerde vacuüm in het nationale recht kunnen ze niet laten opvullen door een andere bepaling.' Soms wordt in dit verband 'objectieve' van 'subjectieve' rechtstreekse werking onderscheiden. ${ }^{88}$ Richtlijnconforme interpretatie en incidentele horizontale werking zouden wel een 'exclusionary effect' kunnen sorteren (werking van het schild hierboven) maar, anders dan bij subjectieve rechtstreekse werking, niet tot 'substitution' (werking van het zwaard) kunnen leiden.

Terecht vragen Craig en De Búrca zich af of deze subtiele vormen van onderscheid in de praktijk wel zo makkelijk te maken vallen: ${ }^{89}$ in zaken als Marleasing ${ }^{90}$ of CIA Security verliest één particulier de zaak en wint de ander de zaak dankzij een richtlijnbepaling die deze particulieren formeel niet - niet zolang het Hof de Marshall I en Faccini Dori rechtspraak handhaaft - tegen elkaar kunnen inroepen.

\subsection{Relevantie van rechtspraak over secundair EU-recht en over publiekrecht ter studie van de invloed van primair EU-recht op privaatrecht}

13. In de mate dat het leerstuk van 'indirecte horizontale werking' zijn oorsprong vindt in het compenseren van afwezige horizontale directe werking van richtlijnbepalingen, dat wil zeggen van secundair Unierecht, past het wellicht niet zeer goed in een studie over de impact van primair EU-recht op nationaal recht. Niet toevallig lijken de mijlpaalarresten van het Hof van Justitie over deze 'indirecte horizontale werking' (Marshall I, Foster, Von Colson en Kamann, Marleasing, Centrosteel/Adipol, Oceano Grupo, CIA Security/Signalson en Securitel, Unilever Italia/Central Food ${ }^{91}$ ) te handelen over conformiteit van nationaal recht met secundaire EU-regelgeving.

afhangen of een werknemer in die onderneming zich wel of niet op richtlijnbepalingen tegen de werkgever mag beroepen. Wordt de betrokken overheidsonderneming geprivatiseerd (zoals met British Gas waartegen Foster ageerde later trouwens is gebeurd), dan kan de werknemer de richtlijnbepaling plots niet meer inroepen tegen de werkgever.

88 P. Craig en G. De Búrca, o.c., p. 270 en p. 296 : 'distinction (...) between the broader concept of direct effect which entails the invocability of EC law, and a narrower concept which relates to the conferral of subjective rights on individuals'.

89 P. Craig en G. De Búrca, o.c., p. 302-303.

90 HvJ EG I3 november 1990. Marleasing SA/La Comercial Internacional de Alimentacion SA, C-Io6/89, Jurispr. I99o, p. I-4I35.

9I Deze arresten zijn in de voorgaande paragrafen geciteerd, op de volgende na: HvJ EG I3 juli 2000, Centrosteel Srl/Adipol GmbH, C-456/98, Jurispr 2000, p. I-6007; HvJ EG 27 juni 200o, Océano Grupo Editorial SA/Roció Murciano Quintero (en andere zaken), C-240/98 tot C-244/98, Jurispr. 2000, p. I-494I; HvJ EG 26 september 2000, Unilever Italia SpA/Central Food SpA, C-443/98, Jurispr. 2000, p. I-7535. 
I4. Daartegen valt op te werpen dat het onderscheid zelf tussen impact van primair EU-recht en impact van secundair EU-recht op nationaal privaatrecht niet steeds even duidelijk te maken valt, in de mate dat alle secundair EU-recht geacht wordt primair EU-recht te implementeren en daarop ook gebaseerd moet zijn. Dat het Belgisch preadvies, zoals het Nederlandse, bij de onderdelen '(Andere) Verdragsbepalingen inzake discriminatie' (infra, § 8) en 'Ambtshalve toepassing' (infra, § Io) ruim aandacht besteedt aan secundair EU-recht, is geen toeval. Anders handelen, zou betekenen dat de meest relevante nationale arresten worden gemist.

Is conforme interpretatie bijvoorbeeld een zaak van impact van primair of secundair EU-recht? In de mate dat geïnterpreteerd wordt in conformiteit met richtlijnen ('richtlijnconforme interpretatie'), lijkt er sprake van impact van secundair recht maar het beginsel van Unietrouw uit art. 4 lid 3 VEU dat aan de plicht tot conforme interpretatie ten gronde ligt, maakt primair recht uit.

I5. Wie de invloed bestudeert van primair EU-recht op nationaal privaatrecht kan aldus het secundair EU-recht niet volledig negeren. Evenzeer lijkt het ons nodig om bij de studie van invloed op privaatrecht soms toch ook aandacht te besteden aan publiekrechtelijke zaken en arresten.

Nemen we opnieuw het voorbeeld van conforme interpretatie. Het allicht belangrijkste Belgische arrest over conforme interpretatie tijdens het afgelopen jaar - met prejudiciële vraagstelling aan het Hof van Justitie, ofschoon die niet rechtstreeks over dit aspect handelde ${ }^{92}$ - was het arrest van het Brusselse Hof van Beroep van eind 2010 in de zaak Spector. ${ }^{93}$ Dit arrest behandelde onder meer de vraag of er een plicht dan wel een verbod bestaat om nationale wetgeving reeds te interpreteren in conformiteit met een richtlijn (in casu een richtlijn over marktmisbruik ${ }^{94}$ ) op een ogenblik dat die richtlijn nog niet moest zijn omgezet. Volgens het Hof van beroep is richtlijnconforme interpretatie in dat stadium zeker niet verplicht. ${ }^{55}$ Ofschoon de vraag in Spector specifiek secundair EU-recht betreft (en er hier derhalve niet verder op wordt ingegaan), lijkt het ter meting van de impact van EU-recht op nationaal privaatrecht niettemin nuttig om een totaalzicht te hebben op de reikwijdte van de plicht tot conforme interpretatie: volgens vaste rechtspraak mag conforme interpretatie niet contra legem en mag er geen verzwaring van strafrechtelijke aansprakelijkheid uit volgen, maar wat voor afloop van een implementatietermijn en wat met verzwaring van niet-strafrechtelijke aansprakelijkheid? Het rechtsgeding in de zaak Spector, dat ons hierin inzicht verschaft, is echter puur publiekrechtelijk van aard (sancties opgelegd door een toezichthouder aan marktpartijen).

I6. Een tweede voorbeeld van publiekrechtelijke zaken die niettemin rechtstreeks privaatrecht kunnen beïnvloeden, vormen strafzaken met burgerlijke partijstelling,

92 HvJ EG 23 december 2009, Spector Photo Group NV en Chris Van Raemdonck/Commissie voor het Bank-, Financie- en Assurantiewezen (CBFA), zaak C-45/o8, Jurispr. 2009, p. I-I2073.

93 Brussel 7 december 20I0, Spector Photo Group NV en Van Raemdonck Chris/Commissie voor het Bank-, Financie- en Assurantiewezen (CBFA), rolnummer 2006/SF/2 (Rep. nr. 2010/8393).

94 Richtlijn 2003/6/EG van het Europees Parlement en de Raad van 28 januari 2003 betreffende handel met voorwetenschap en marktmanipulatie (marktmisbruik), Pb. L 96/I6, I2 april 2003.

95 Zie in die zin ook P. Craig en G. De Búrca, o.c., p. 29I-292 met verwijzing naar HvJ EG 4 juli 2006, Konstantinos Adeneler e.a./Ellinikos Organismos Galaktos(ELOG), Jurispr. 2006, 6057. 
met andere woorden strafzaken (publiekrecht) waarin meteen ook uitspraak wordt gedaan over aansprakelijkheid (privaatrecht). Wie de strafzaak negeert, mist het (in Nederland en België privaatrechtelijke, supra, I.I) aansprakelijkheidsaspect. Wederom levert de Belgische rechtspraak van het afgelopen jaar een mooi voorbeeld, namelijk de zaak Citibank, die grote publieke belangstelling genoot. Citibank Belgium SA (Citibank) en bepaalde bestuurders en directeurs werden strafrechtelijk vervolgd en in eerste aanleg veroordeeld - en schadevergoeding aan de burgerlijke partijen werd toegekend - voor de commercialisering van vermeend complexe financiële producten die na het faillissement van Lehman Brothers in de Verenigde Staten hun waarde hadden verloren. Een van de gronden van vervolging en veroordeling was de vermeende schending van de wet van I6 juni 2006 op de openbare aanbieding van beleggingsinstrumenten en de toelating van beleggingsinstrumenten tot de verhandeling op een gereglementeerde markt, ${ }^{6}$ omdat Citibank promotie zou hebben gemaakt voor de geviseerde financiële producten zonder voorafgaandelijke goedkeuring door de Commissie voor het Bank-, Financie- en Assurantiewezen (CBFA). Citibank had voor de rechtbank betoogd dat de verplichting tot voorafgaandelijke goedkeuring strijdig is met EU-recht ${ }^{97}$ en had de rechtbank verzocht hierover een prejudiciële vraag te stellen aan het Hof van Justitie. De rechtbank weigerde en veroordeelde op grond van de overweging dat het EU-recht controle in het gastland, naast controle in het thuisland, niet uitsluit. ${ }^{8}$

I7. Bij wijze van derde voorbeeld kan worden verwezen naar algemene beginselen van Unierecht. De wijze waarop het Hof van Justitie bijvoorbeeld invulling geeft aan het beginsel van procedurele autonomie van lidstaten ${ }^{99}$ in publiekrechtelijke zaken is rechtstreeks relevant ter studie van de impact van (primair, ditmaal) EU-recht op privaatrecht. Er gelden immers geen twee verschillende beginselen van procedurele autonomie in publiek- en privaatrechtelijke zaken. Een recent en relevant Belgisch arrest in dit verband, zoals Spector opnieuw gewezen door het Hof van beroep te Brussel en opnieuw met een prejudicieel arrest van het Hof van Justitie tot gevolg, is het arrest VEBIC. ${ }^{\text {10o }}$ Bekeken vanuit een oogpunt van procedurele autonomie was

96 B.S. 2 I juni 2006. Artikelen 60 en $69,2^{\circ}, 4^{\circ}, 5^{\circ}$ en $8^{\circ}$ zouden geschonden zijn.

97 Ingeroepen werd 'Prospectusrichtlijn' 2003/7I/EG van het Europees Parlement en de Raad van 4 november 2003 betreffende het prospectus dat gepubliceerd moet worden wanneer effecten aan het publiek worden aangeboden of tot de handel worden toegelaten en tot wijziging van Richtlijn 200I/34/EG, Pb, L 345/64, 3I december 2003.

98 Vonnis van de rechtbank van eerste aanleg te Brussel van I december 2010.

99 'Volgens vaste rechtspraak van het Hof (zie met name de arresten van I6 december 1976, zaak 33/76, Rewe, Jurispr. 1976, blz. I989, en 9 november 1983, zaak 199/82, San Giorgio, Jurispr. I983, blz. 3595) is het, bij ontbreken van een desbetreffende gemeenschapsregeling, een aangelegenheid van de nationale rechtsorde van elke Lid-Staat om de procesregels te geven voor de rechtsvorderingen met het oog op de bescherming van de rechten welke de justitiabelen aan de rechtstreekse werking van het gemeenschapsrecht ontlenen, met dien verstande dat deze regels niet ongunstiger mogen zijn dan die voor soortgelijke nationale vorderingen en ook niet van dien aard, dat zij de uitoefening van door de communautaire rechtsorde verleende rechten praktisch onmogelijk maken.' Het citaat komt uit het arrest Emmott (HvJ EG 25 juli 199I, Theresa Emmott/ Minister for Social Welfare en Attorney General, C-208/9o, Jurispr. I99I, p. I-4269, r.o. I6) maar staat in gelijkaardige vorm in talrijke arresten.

Iоo $\mathrm{HvJ} \mathrm{EU} 7$ december 2010, Vlaamse federatie van verenigingen van Brood- en Banketbakkers, IJsbereiders en Chocoladebewerkers (VEBIC) VZW, C-439/08, nog niet gepubliceerd in de Juris- 
de vraag aan de orde of EU-mededingingsrecht vereist dat in mededingingszaken wordt afgeweken van het principe van Belgisch procesrecht dat een rechter (zoals de Raad voor de Mededinging, die een administratief rechtscollege is) zijn/haar beslissing niet ter zitting toelicht voor een hoger rechtscollege. Het Hof van Justitie lijkt een salomonsoordeel te vellen: (I) nationaal recht moet een NCA het recht verlenen om als verwerende partij deel te nemen aan een procedure in rechte tegen haar beslissing, (2) welk onderdeel van de NCA deelneemt, bepaalt dat nationaal recht overeenkomstig 'het beginsel van procedurele autonomie' zelf - het hoeft dus geen rechtscollege te zijn, zodat de homogeniteit van het Belgisch recht gevrijwaard blijft - maar (3) als de NCA stelselmatig niet verschijnt, '[wordt] het nuttig effect van de artikelen IoI VWEU en I02 VWEU echter in gevaar gebracht', zonder dat wordt aangegeven welk rechtsgevolg dit zou hebben. Opvallend is dat het Hof 'het beginsel van procedurele autonomie' noemt, ook in het dictum, en er een deel van zijn beslissing op baseert zonder evenwel te herhalen wat dit beginsel inhoudt.

I8. We besluiten dat bij de studie van de invloed van primair EU-recht op nationaal privaatrecht, het secundaire EU-recht en 'publiekrechtelijke' arresten niet volledig buiten beschouwing kunnen blijven. Dit gezegd zijnde, beperken we die rol in de rest van het preadvies: in het licht van de opgegeven titel, spitsen we ons toe op de invloed van primair recht in privaatrechtelijke zaken. We gaan hier derhalve niet verder in op vragen van doorwerking van EU-recht die specifiek secundair EUrecht betreffen (behalve het vraagstuk van richtlijnconforme interpretatie wint o.i. vooral de vraag naar het minimum of maximum harmoniserend karakter van richtlijnen aan belang; die vraag stond aan de orde in de hierboven vermelde Spector- en Citibank-zaken, ${ }^{\text {10 }}$ in arresten over productaansprakelijkheid ${ }^{\text {102 }}$ en in andere arresten over consumentenrecht).

\section{§ 5 Mededingingsrecht: artikelen IOI en IO2 VWEU}

I9. Wie bepalingen schendt van kartelrecht (art. IOI-IO2 VWEU en de tegenhangers daarvan in het nationale recht) loopt drie risico's: nietigheid van de overeenkomst (infra, 5.I), beboeting (publiekrechtelijke afdwinging - publiekrecht dat hier niet ter sprake komt), en een schadevergoedingsactie (private afdwinging van mededingingsrecht infra, 5.2).

prudentie. Hierover P. Van Cleynenbreugel, 'Transforming shields into swords. The VEBIC judgment, judicial standards of national procedure and the emergence of procedural heteronomy in EU law', MJ, te verschijnen.

Ior Zie p. I75-I76 van het aangehaalde vonnis in Citibank evenals de eerste door het Hof van Beroep te Brussel gestelde prejudiciële vraag in Spector: 'Vormen de voorschriften uit [Richtlijn 2003/6], inzonderheid ook artikel 2 ervan, een volledige harmonisering, met uitzondering [van] de bepalingen die aan de lidstaten expliciet een vrije invulling van de maatregelen laten, of betreffen ze in hun geheel een minimumharmonisering?' Het Hof van Justitie ging in het hierboven geciteerde arrest 23 december 2009 op deze vraag niet in.

Io2 Supra, randnr. 6. 


\title{
5.I Nietigheid van met het kartelrecht strijdige overeenkomsten
}

\author{
Europeesrechtelijke aard van de nietigheidssanctie. Verschil met wat in België gebruikelijk is s $^{103}$
}

20. Toepassing van het mededingingsrecht kan een einde stellen aan overeenkomsten, nu art. Ior lid 2 VWEU bepaalt dat een overeenkomst of een onderling afgestemde feitelijke gedraging die strijdig is met het eerste lid van dat artikel en die niet vrijgesteld kan worden op grond van art. Ior lid 3 of een verordening uitgevaardigd op grond daarvan (zoals een groepsvrijstelling) 'van rechtswege nietig' is.

Wat juist wordt bedoeld met de uitdrukking 'van rechtswege nietig' (in de Engelstalige tekst 'automatically void') is niet meteen duidelijk. Het Verdrag bevat immers geen verdere precisering. ${ }^{\text {.04 }}$

2I. Uit een lezing en vergelijking van de verschillende versies van het (toen nog) EG-Verdrag besluiten Cornelis en Gilliams dat het hier gaat om een nietigheid die in beginsel geen rechterlijke beslissing behoeft (zie ook art. I, eerste en tweede lid Vo. I/2003). ${ }^{105}$ Het gaat om een soort automatische nietigheid, 'une nullité de plein droit, en ce sens que l'intervention du juge ne serait pas nécessaire pour obtenir l'annulation de l'accord incompatible avec le marché commun'. ${ }^{\text {106 }}$

Dit kan vreemd lijken wanneer men redeneert vanuit het Belgische civiele (proces-)recht, waarin het ter wille van de rechtszekerheid steeds vereist is dat een rechter uitspraak doet over de vraag of de noodzakelijke voorwaarden om tot nietigheid te besluiten voldaan zijn en desgevallend de nietigheid vaststelt. Naar Belgisch recht werkt de nietigheid met andere woorden in beginsel niet 'van rechtswege'. ${ }^{107}$

In het geval van art. Ior lid 2 VWEU gaat het evenwel om een nietigheid sui generis die zich voordoet los van enige rechterlijke uitspraak. De restrictieve afspraak is, ook zonder tussenkomst van de rechter, $a b$ initio onbestaand. ${ }^{108}$ Dat wil echter niet zeggen dat de rechter geen rol meer te spelen heeft. Indien de partijen bij de restrictieve overeenkomst het niet eens zijn over de al dan niet toepasselijkheid van het

I03 Randnrs. 20-23 van dit preadvies vormen een slechts miniem gewijzigde overname uit S. De Dier en W. Devroe., o.c., p. 513-5I5.

I04 F. Hubeau, 'La nullité, au sens de l'article 85, § 2 du Traité CEE, des accords et décisions incompatibles avec le Marché commun', in : Liber Amicorum Josse Mertens de Wilmars, Antwerpen: Kluwer I982, p. IOI.

I05 L. Cornelis en H. Gilliams, 'Private parties' entitlement to damages on account of infringements of the competition rules: Belgian law as an example of the 'civil law' approach', in: J. Stuyck en H. Gilliams (red.), Modernisation of Euopean competition law, Antwerpen/Oxford/New York: Intersentia 2002, p. I6o.

Io6 F. Hubeau, o.c., p. I03.

I07 C. Renard en E. Vieujean, 'Nullité, inexistence et annulabilité en droit civil belge', Ann. fac. dr. Liège I962, p. 263; L. De Gryse, 'De nietigheid in het algemeen overeenkomstenrecht', in: Actuele problemen van het arbeidsrecht, Antwerpen: Kluwer 1987, (304), p. 306-307. Zie ook: F. Hubeau, 'La nullité, au sens de l'article 85, § 2 du Traité CEE, des accords et décisions incompatibles avec le Marché commun', o.c., p. I03, die aldus besluit dat de nietigheid van rechtswege als dusdanig in het Belgische recht niet bestaat. Vgl. art. III7 B.W.

Io8 J. Stuyck verwijst in dit geval naar de Duitse 'Nichtigkeit', wat wordt opgevat als 'inexistentie': 'Civielrechtelijke gevolgen naar Belgisch recht van inbreuken op de kartelbepalingen van het E.E.G.-Verdrag', in: Liber Amicorum Jan Ronse, Brussel: Story-Scientia I986, nr. I9, p. 727. 
betrokken verbod, leggen zij hun dispuut voor aan de rechter, die in voorkomend geval de nietigheid op declaratieve wijze vaststelt. ${ }^{\text {109 }}$

22. Het automatisch karakter van de nietigheid brengt ook mee dat de rechter die tot de bevinding komt dat een overeenkomst of een gedraging strijdig is met art. IoI lid I VWEU, de nietigheid (desnoods ambtshalve) zal moeten uitspreken, zonder dat hij hierbij rekening kan houden met de bedoeling van de partijen om al dan niet een restrictieve overeenkomst te sluiten. ${ }^{\text {IIO }}$ Het gaat dus om een verplichte nietigheid. ${ }^{\text {III }}$

23. Bovendien kan de nietigheid op elk moment (in elke stand van het geding) en door elke belanghebbende worden opgeworpen. Zo kunnen bijvoorbeeld de uitgesloten ondernemingen bij selectieve of exclusieve distributie de nietigheid opwerpen. Het betreft dus een absolute nietigheid, nu het mededingingsrecht volgens het Hof van Justitie een hoeksteen uitmaakt van de communautaire rechtsorde (zie ook art. 3, eerste lid, g) EG-Verdrag). ${ }^{\mathrm{II2}}$ Het Hof heeft dit bevestigd. ${ }^{1{ }^{13}}$

\section{Toepassing in België}

24. Elders zijn we op de gevolgen van de nietigheid naar Belgisch recht uitvoerig ingegaan, ${ }^{\mathrm{II} 4}$ hierna geven we de hoofdpunten weer met toepassingen.

25. In België is er heel wat rechtspraak over de nietigheidsanctie van art. Ior lid 2 VWEU. Men zal zich trouwens herinneren dat het Hof van Justitie zijn eerste arresten over deze sanctie wees in antwoord op prejudiciële vragen gerezen in betwistingen voor een Belgische rechter (de rechtbank van koophandel te Luik) over een brouwerijcontract. ${ }^{115}$

26. Ook naar Belgisch recht heeft de nietigheid terugwerkende kracht ${ }^{116}$ en betreft het een 'absolute nietigheid', wat inhoudt dat ze kan worden ingeroepen door elke belanghebbende partij en ook ambtshalve door de rechter. In België wordt voorts aangenomen dat deze nietigheid van openbare orde is. ${ }^{117}$ Absolute nietigheid en openbare orde gaan in België hand in hand. Uit het openbare-ordekarakter van

Iog Ibid.

IIo H. Gilliams en L. Cornelis, 'Private enforcement of the competition rules in Belgium', T.B.M. 2007, nr. Io, p. I4; F. Hubeau, o.c., p. I07. Zie ook HvJ EG 20 september 200I, Courage Ltd./Bernard Crehan, supra, voetnoot 27, r.o. 22.

III L. De Gryse, l.c., p. 308.

II2 HvJ EG I2 september 2000, Pavlov e.a., I80/98, Jurispr. 2000, I-645I; HvJ EG I juni I999, Eco Swiss China Time, I26/97, Jurispr. 1999, 3035.

II3 HvJ EG 20 september 200I, Courage Ltd./Bernard Crehan, supra, voetnoot 27, r.o. 22; HvJ EG 25 november 1971, Béguelin, 22/71, Jurispr. I97I, 962, r.o. 29.

II4 S. De Dier en W. Devroe, o.c., 515-526 ('Gevolgen van de nietigheid naar nationaal verbintenissenrecht').

II5 HvJ EG I2 december I967, Brasserie Haacht/Wilquin en Janssen (Haacht I), 23/67, Jurispr. I967, 525; HvJ EG 6 februari 1973, Brasserie Haacht/Wilquin en Janssen, $48 / 72$ (Haacht II), Jurispr. I973, 77 .

II6 Arrest Haacht II, supra, vorige voetnoot, r.o. 37; zo ook Brussel 28 september 2004, Jaarboek Handelspraktijken \& Mededinging 2004, p. 925.

II7 W. Van Gerven, L. Gyselen-M. Maresceau, J. Stuyck en J. Steenbergen, Beginselen van Belgisch Privaatrecht, XIII: Handels- en economisch recht, deel II. Mededingsrecht B kartelrecht, Antwerpen: StoryScientia 1996, p. I7I; H. Gilliams en L. Cornelis, 'Private enforcement of the competition rules in Belgium', Tijdschrift voor Belgisch Mededingingsrecht 2007, nr. 2, p. I3. 
deze nietigheidsanctie vloeit ondermeer voort dat het adagium 'nemo auditur suam turpitudinem allegans' een partij niet verhindert zich te beroepen op een inbreuk waarvoor zij persoonlijk aansprakelijk kan worden gesteld, teneinde een nietigverklaring van de overeenkomst te verkrijgen. ${ }^{\mathrm{II} 8}$ Anderzijds kan een partij niet de uitvoering vragen van een contractuele verbintenis wanneer die verbintenis strijdig is met de mededingingsregels, zelfs indien die verbintenis door de andere partij met kennis van zaken is aanvaard.

27. In de literatuur wordt verdedigd dat een overeenkomst die nietig is ingevolge art. IOI, lid 2, VWEU niet in aanmerking komt voor conversie. ${ }^{\text {II }}$

Het Hof van beroep te Antwerpen besliste dat de Belgische rechter niet over de matigingsbevoegdheid beschikt om de nietigheid te herleiden. ${ }^{120}$

28. Volgens vaststaande rechtspraak van het Hof van Justitie strekt de nietigheid zich alleen uit tot de onderdelen van de overeenkomst, die ingevolge art. Ior, lid 2, verboden zijn. De gehele overeenkomst is slechts nietig, wanneer die onderdelen niet van de overeenkomst zelf kunnen worden losgemaakt. ${ }^{121}$ Ook deze rechtspraak is bevestigd door Belgische rechtbanken. ${ }^{\mathrm{I} 22}$

29. In het licht van vaststaande rechtspraak van het Hof van Justitie ${ }^{\mathrm{I} 23}$ is het onbestreden dat de gevolgen van de nietigheid van een afspraak met inbegrip van de weerslag daarvan op latere overeenkomsten of rechtshandelingen die in het kader van deze afspraak gesloten werden, volgens het toepasselijk nationaal recht moeten worden bepaald. ${ }^{124}$

30. Nietigheid veronderstelt restitutio in integrum. Overeenkomsten tussen partijen, zoals koopovereenkomsten, die op grond van een nietige kartelafspraak reeds werden uitgevoerd, zullen echter moeilijk ongedaan kunnen worden gemaakt. In dat geval zal de status quo ante moeten worden bereikt bij wege van equivalent. ${ }^{125}$ Hierover is ons evenwel geen rechtspraak bekend.

3I. De geldigheid van een overeenkomst tussen één partij bij een met art. Ior lid I VWEU strijdige overeenkomst en een derde zal in principe niet door de nietigheid van art. Ior lid 2 VWEU worden aangetast. Mogelijk leidt de nietigheid van een contract of een beding daarin wegens strijdigheid met art. IoI VWEU toch tot nietigheid van vervolgovereenkomsten die op grond van dit nietig contract of beding (maar niet tussen dezelfde partijen) werden gesloten wegens ongeoorloofde oorzaak (art. IIo8 B.W.).

II8 Zie W. Van Gerven e.a., o.c., I7I.

II9 Gilliams-Cornelis, o.c., I4; cfr. A. Hartkamp, Nederlands preadvies en de daar geciteerde rechtspraak.

I20 Antwerpen 25 mei 2009, Jaarboek handelspraktijken en Mededinging, 2009, p. 998.

I2I HvJ EG 3o juni I966, Société Technique minière, 56/65, Jurispr. I966, 392; HvJ EG 28 februari I99I, Delimitis, C-234/89, Jurispr., I-977, r.o. 40.

I22 Brussel, 23 november I995, Jaarboek Handelspraktijken \& Mededinging I995, p. 645; Brussel, 28 juni I995, Jaarboek Handelspraktijken \& Mededinging I995, p. 576; Brussel, 23 januari 2007, Tijdschrift voor Belgisch Mededingingsrecht 2007, p. I03.

I23 Zie o.m. de arresten Haacht I en Haacht II hierboven geciteerd.

I24 Zie ook W. Van Gerven e.a., o.c., p. I70.

I25 Zie ook H. Gilliams-L. Cornelis, o.c., p. I5. 
Of voor een dergelijke overeenkomst een wilsgebrek kan worden ingeroepen zal afhangen van de aard van het gebrek. Bij dwaling moet het gaan om een dwaling over het voorwerp van de verbintenis, bijvoorbeeld de prijs wanneer degene die de dwaling inroept de afnemer is van een product waarvan de prijs in strijd met de mededingingsregels werd vastgesteld.

Het Hof van Beroep te Gent ${ }^{126}$ oordeelde dat de klant van een interieurarchitect verschoonbaar gedwaald had over het ereloon dat voortvloeide uit een met het kartelverbod strijdige 'deontologische norm', een schaal van erelonen die door de vereniging van interieurarchitecten was vastgelegd en die deel uitmaakte van het door de interieurarchitect gehanteerd modelcontract. ${ }^{\mathrm{I} 7}$ De klant gaf volgens het Hof van Beroep zijn toestemming onder een verkeerde voorstelling van zaken. Hij besefte namelijk niet dat de gehanteerde schaal van erelonen in strijd was met de mededingingswet. Over de gevolgen hiervan is het arrest minder duidelijk. Verschoonbare dwaling over 'de zelfstandigheid van de zaak die het voorwerp van de overeenkomst vormt' leidt tot relatieve nietigheid op verzoek van de debiteur van die verbintenis (art. II о B.W.). De klant van de interieurarchitect had niet gedwaald over de zelfstandigheid van de zaak, met name de prestatie van de interieurarchitect. Het Hof verbindt aan de dwaling dan ook niet de nietigheid, maar acht, in een weinig gemotiveerd arrest, het overeengekomen ereloon blijkbaar niet afdwingbaar. Merkwaardigerwijs bepaalt het Hof zelf het ereloon.

Het is niet zonder meer evident dat, wanneer ondernemingen die zelf geen partij zijn bij een inbreuk op het kartelverbod een prijs overeenkomen die wordt afgeleid uit een schaal die deel uitmaakt van een besluit van een ondernemingsvereniging dat in strijd is met het kartelverbod, de prijs zelf nietig zouden horen verklaren wegens strijdigheid met het kartelverbod. Op het eerste gezicht zou men denken dat de klant van de interieurarchitect in een dergelijk geval een vordering tot schadevergoeding zou hebben op de ondernemingsvereniging die in strijd met het kartelverbod de schaal had vastgesteld. Daarbij zou de klant moeten kunnen aantonen dat de interieurarchitect bij afwezigheid van een dergelijke schaal, een lager ereloon zou hebben gevraagd. In bevestigend geval zal zijn schade gelijk zijn aan het verschil tussen het aangerekend ereloon en het ereloon dat de architect zonder die schaal zou hebben gevraagd. Het besluit van de ondernemingsvereniging zou immers de onrechtmatige daad zijn die de schade heeft veroorzaakt (aangenomen dat de architect aan dat besluit gebonden was of in de overtuiging leefde dat hij daaraan gebonden was). Bij een schadeclaim van de klant tegen de vereniging zou wel de vraag rijzen of er zijdens de interieurarchitect geen verrijking zonder oorzaak heeft plaatsgevonden.

I26 Gent I5 februari 2008, Jaarboek Handelspraktijken \& Mededinging, 2008, p. 8I4

I27 Beschikking 2005/8/EG van de Commissie van 24 juni 2004 in zaak zaak COMP/A.38549-Belgische Orde van Architecten - Beschikking tot toepassing van artikel 8I, met oplegging van een boet (samenvatting $\mathrm{Pb}$. L 4/I0, 6 januari 2005; volledige tekstversie http://ec.europa.eu/ competition/antitrust/ cases/dec_docs/38549/38549_74_I.pdf). 
32. Het Hof van beroep te Brussel ${ }^{128}$ oordeelde dat de nietigheid van art. Ior lid 2 VWEU dient te worden beoordeeld op het moment waarop een geschil omtrent een zaak rijst en aan de rechter wordt voorgelegd. Indien de nietigheid zou worden beoordeeld op enig vroeger moment dan zou dat een partij in staat stellen de nietigheid van de overeenkomst op te werpen om te ontsnappen aan een contractuele verplichting die zij gedurende een bepaalde tijd vrijwillig en zonder voorbehoud heeft uitgevoerd. Dit arrest dient goed te worden begrepen, in het licht van de specifieke omstandigheden van de zaak: op het moment waarop de partij (een caféhouder) tegen de wederpartij (een brouwerij) de nietigheid van een exclusief afnamebeding uit een in 1987 gesloten bierleveringscontract inriep, was Groepsvrijstellingsverordening 2790/1999 in werking getreden, ${ }^{129}$ die het afnamebeding vrijstelde. De uitspraak lijkt redelijk maar nu het Hof van Beroep geen prejudiciële vraag heeft voorgelegd aan het Hof van Justitie is het niet zeker of ze ook juist is.

33. Bij misbruik van machtspositie in strijd met art. IO2 VWEU legt het Verdrag geen nietigheidssanctie op. Deze aangelegenheid wordt derhalve volledig aan het nationale recht overgelaten. Voor nietigheid komt uiteraard alleen in aanmerking het misbruik van machtspositie dat de vorm aanneemt van ofwel een contractuele afspraak ofwel een besluit van een ondernemingsvereniging.

Het fenomeen 'ik dacht dat ikeen contract met $u$ had'

34. Opgang lijkt het fenomeen te maken dat wij 'ik dacht dat ik een contract met u had' noemen en dat hierin bestaat dat een contractpartij, hetzij uit oprechte bekommernis om naleving van EU-recht hetzij om minder nobele motieven, nietigheid wegens schending van art. Ior lid I VWEU inroept om aan contractuele verplichtingen een einde te stellen (te ontsnappen?). Het past om dit fenomeen op precies dit punt in het preadvies te signaleren, aangezien de zonet besproken nietigheid wordt ingeroepen in een actie die als 'private afdwinging van mededingingsrecht' (infra, 5.2) zou kunnen gelden, ware het niet dat die terminologie tegenwoordig wordt gereserveerd voor schadevergoedingsacties.

35. Het inroepen in contractuele geschillen van EU-recht, sterk omwille van de primauteit ervan, is ongetwijfeld niet nieuw maar met de groeiende kennis van het mededingingsrecht in het algemeen en de nietigheidssanctie van art. IOI lid 2 VWEU in het bijzonder, kan een groei gepaard gaan van het aantal toepassingsgevallen.

I28 Brussel, 23 juni 2005, Jaarboek Handelspraktijken \& Mededinging, 2005, p. 76r e.v., noot Y. Montangie, 'Prejudiciële vragen in de WBEM en de draagwijdte van de nietigheidssanctie van het Europese kartelverbod'.

I29 Verordening (EG) nr. 2790/I999 van de Commissie van 22 december 1999 betreffende de toepassing van artikel 8I, lid 3, van het Verdrag op groepen verticale overeenkomsten en onderling afgestemde feitelijke gedragingen, $\mathrm{Pb}$. L 336/21, 29 december 1999. Deze verordening trad in werking vanaf I januari 2000 en werd van toepassing vanaf I juni 2000 . Ondertussen is de verordening alweer vervangen, door Verordening (EU) nr. 330/2010 van de Commissie van 20 april 20 I betreffende de toepassing van artikel IoI, lid 3, van het Verdrag betreffende de werking van de Europese Unie op groepen verticale overeenkomsten en onderling afgestemde feitelijke gedragingen, $\mathrm{Pb}$. L IO2/I, 23 april 2010. 
De beste illustratie vormt uiteraard de zaak Courage/Crehan zelf. Men kan zich de verbijstering voorstellen van de brouwerij die, in de overtuiging dat ze met een eenvoudige invorderingsactie te maken heeft, nietigheid van de bierleveringsovereenkomst tegengeworpen krijgt (mét schadevergoedingsactie, zie 5.3 hierna, en met het risico te worden aangemerkt als sterkere contractpartij die niet mag ageren terwijl de 'zwakkere' tegenpartij dat wel mag).

In België is wellicht het best een zaak bekend waarbij de Profliga van het Belgische voetbal, agerend als vertegenwoordiger van de voetbalclubs, uitzendrechten voor voetbal in eerste klasse verkocht. In mei 2004 besloot de Profliga dat het omwille van het mededingingsrecht niet mogelijk was om een contractclausule na te leven die haar ertoe verplichtte om na afloop van een contract over exclusieve toewijzing van de uitzendrechten aan één onderneming (Canal+ Belgique SA), eerst exclusief met die onderneming te onderhandelen over een hernieuwing van de overeenkomst. De Profliga besloot, onder verwijzing naar het mededingingsrecht, om in de plaats daarvan de uitzendrechten in verschillende loten te veilen. ${ }^{\mathrm{I}}{ }^{\circ}$ Dit leidde op zijn beurt tot mededingingsrechtelijke betwistingen ${ }^{13 \mathrm{I}}$ maar bleek voor de Profliga en de voetbalclubs financieel erg interessant.

We kennen minstens twee gelijkaardige gevallen in België maar we vermoeden dat er beduidend meer zijn. Eén geval betreft een onderneming die ooit over een distributiemonopolie beschikte en die, ongetwijfeld met de overtuigingskracht die van dat monopolie uitging, langdurige overeenkomsten heeft gesloten met producenten die, nu het monopolie is opgeheven, elders veel betere voorwaarden kunnen bekomen. Het andere situeert zich in de financiële sector.

\subsection{Private afdwinging van mededingingsrecht: aansprakelijkheid wegens schending van het kartelrecht}

36. Een potentieel veel grotere invloed op nationaal privaatrecht dan de loutere nietigheidssanctie van art. Ior lid 2 VWEU heeft de zogenoemde 'private afdwinging' van mededingingsrecht.

\section{Concept}

37. Publieke afdwinging (public enforcement) van mededingingsrecht gaat uit van (a) publieke autoriteiten, die (b) op EU- of nationaal niveau, (c) beslissingen uitvaardigen die (d) in het algemeen belang (e) bevelen om mededingingsbeperkend gedrag te stoppen of dit gedrag beboeten (incl. immuniteit of vermindering verlenen, verbintenissen aanvaarden, schikkingen overeenkomen). Beboeting door de Commissie of

\footnotetext{
I30 Zie Beslissing nr. 2005-I/O-40 van de Raad voor de Mededinging van 29 juli 2005 in zaken MEDE-I/O-05/0025 en MEDE-P/K-05/0036: De verkoop door de Liga Beroepsvoetbal (LBV) van de uitzendrechten voor wedstrijden van de nationale voetbalcompetitie voor de seizoenen 2005-2006, 2006-2007 en 2007-2008 van 29 juli 2005, Driemaandelijks tijdschrift van Rechtspraak, nr. 2005/03, p. 28-48 (economie.fgov.be/ nl/binaries/jurisprudence_2005_03_tcm325-288ri.pdf).

I3I Bij arrest van 28 juni 2006 bevestigde het Hof van Beroep te Brussel de beslissing van de Raad voor de Mededinging. Zie TBM 2007, p. 63-72.
} 
door nationale mededingingsautoriteiten (national competition authorities of NCAs) vormt de best gekende vorm van publieke afdwinging van mededingingsrecht. Het afschrikwekkend effect ervan is de afgelopen jaren sterk toegenomen. Toch komt een minstens even grote dreiging voor marktoperatoren - of, afhankelijk van het perspectief, een even grote zegen voor benadeelde partijen - nu dus uit andere hoek, die van de private afdwinging.

Private afdwinging (private enforcement) gaat uit van (a') particulieren (natuurlijke of rechtspersonen) die (b') via de nationale rechtscolleges (c') vonnissen en arresten afdwingen waarbij (d') ter bescherming van hun private belangen (e') schadevergoeding wordt toegekend. De in België sterk ontwikkelde praktijk van vorderingen tot staken én het hierboven beschreven fenomeen 'ik dacht dat ik met u een contract had' zouden eveneens als vormen van private afdwinging kunnen worden beschouwd maar in het algemeen geldt nu dat wanneer naar 'private afdwinging van mededingingsrecht' wordt verwezen, daar een aspect van vordering van schadevergoeding aan is verbonden. Het is ook met die inhoud dat we de term hierna hanteren.

38. Uit bovenstaande omschrijving blijkt complementariteit en verschil. De Commissie en de NCAs kunnen beboeten maar kunnen geen schadevergoeding toekennen. Een nationale rechter in burgerlijke zaken kan schadevergoeding toekennen maar niet beboeten. Niet slechts qua partijen en qua beoogd resultaat maar ook qua bewijsvoering verschillen beide vormen van afdwinging grondig. Een verschil ten slotte dat te vaak over het hoofd wordt gezien betreft de beschermde belangen: terwijl een NCA of de Commissie optreedt in het algemeen belang, weegt de nationale burgerlijke rechter private belangen tegen elkaar af. Het gebeurt nog te vaak dat gedingpartijen op een bepaald ogenblik besluiten om een schikking uit te werken waarvan de belofte deel uitmaakt om alle hangende procedures te stoppen, zonder te beseffen dat een procedure voor een NCA of de Commissie niet kan worden beëindigd op eenvoudige aanvraag van de betrokken partijen. Een NCA of de Commissie beslist enkel in het algemeen belang tot seponering of voortzetting van een begonnen procedure.

39. Wat private afdwinging betreft, onderscheidt men best duidelijk tussen enerzijds de plannen van de Commissie over een mogelijke harmonisering van geldend nationaal recht, die dus nog niet tot geldend recht hebben geleid, en anderzijds de bestaande rechtspraktijk, waarin ook zonder EU-recht, steeds meer schadevergoedingsacties worden ingesteld voor nationale rechtbanken. De Europese initiatieven beogen elementen van nationaal aansprakelijkheids- en procedurerecht te harmoniseren om schadevergoedingsacties makkelijker en meer eenvormig te maken binnen de EU. Zonder zulke harmonisatie kunnen schadevergoedingsacties echter even goed doorgang vinden, maar dan op grond van niet geharmoniseerd nationaal aansprakelijkheids- en procedurerecht.

We verwijzen naar paragraaf 3 hierboven over de tweevoudige wijze waarop de impact van het Europees recht op het privaatrecht kan worden bestudeerd. Volgens de eerste benadering heeft private afdwinging nu reeds een invloed op privaatrecht (meer aansprakelijkheden, overeenkomsten anders geformuleerd of niet gesloten wegens angst voor private afdwinging). Invloed volgens de tweede benadering zal volgen zodra een EU-rechtsinstrument over private afdwinging van 
mededingingsrecht afdwingbaar wordt en kan dan, omwille van het homogeniteitsprobleem en de spontane harmonisatie van aansprakelijkheidsrecht die eruit kan volgen (supra, randnr. 7), het domein van het mededingingsrecht ver overstijgen.

\section{Private afdwinging naar geldend recht}

40. Private schadevergoedingsacties kunnen van het follow-on type zijn, wat betekent dat de vordering wordt ingesteld in opvolging van een (boete-)beslissing tot publieke afdwinging. De eisers zullen dan argumenteren dat de onrechtmatige daad bewezen is door de eerdere veroordeling van de verweerders of door de erkenning door de verweerders van een schending van de mededingingsregels in het kader van de clementieregeling of de nieuwe schikkingsregeling.

Inclusief een vernietigingsberoep voor het Gerecht en een mogelijk beroep tegen de uitspraak daarvan bij het Hof van Justitie kunnen procedures over publieke afdwinging op Europees niveau vele jaren in beslag nemen. Op nationaal niveau ligt dat niet anders. Uiteraard hoeven eisers in schadevergoedingsacties op de uitkomst van deze procedures niet te wachten en kunnen ze hun schadevergoedingsactie ook onafhankelijk van de publieke afdwinging instellen (stand alone actie). De bewijslast wordt dan wel zwaarder.

4I. In Europa, dat tot dusver niet dezelfde claims culture kende als de Verenigde Staten, zijn de eerste gespecialiseerde advieskantoren ondertussen opgericht en neemt het aantal schadevorderingsacties wegens schending van mededingingsrecht toe. Er blijkt een zekere forum shopping mogelijk en vooral in het Verenigd Koninkrijk is dit soort schadevergoedingsacties spectaculair gestegen - wat overigens niet steeds zichtbaar is in de rechtspraak aangezien de meeste acties met een schikking buiten de rechtbank eindigen.

42. In België zijn verschillende zaken hangende maar van een stormloop is nog geen sprake. Het aantal zaken geeft echter slechts een deel weer van de realiteit van private afdwinging. Feit is, dat het risico op private afdwinging ondertussen dermate groot is en de band tussen publieke en private afdwinging dermate nauw, dat niemand nog beslissingen kan nemen over publieke afdwinging (zo bijvoorbeeld bij het voeren van verweer tegen kartelboetes of bij het beslissen over een mogelijke aanvraag tot clementie) zonder bij die beslissingen rekening te houden met de mogelijke gevolgen op het gebied van private afdwinging. Zo leert de ervaring in het Verenigd Koninkrijk dat de aanvragers van clementie de eersten zijn die met een schadevergoedingsactie worden geconfronteerd omdat het bewijs van de inbreuk (en de fout) zoveel evidenter is. Het nieuwe systeem van 'schikkingen' houdt eveneens een erkenning in van een inbreuk, en zou dus hetzelfde onverwachte gevolg kunnen opleveren: wie gemoedsrust beoogt via een clementieaanvraag of schikking, wordt integendeel het eerste 'slachtoffer' van private afdwinging. Immuniteit of boetevermindering voor wie 'clementie' aanvraagt, biedt geen bescherming tegen private schadevergoedingsacties.

De ervaring in het Verenigd Koninkrijk leert dat ook het soort beroep dat tegen een boete wordt ingesteld, een private schadevergoedingsactie kan bespoedigen of vertragen. Engelse rechters oordeelden dat beroepen die enkel tegen de hoogte van 
de boete zijn gericht en geen of geen uitgewerkt verweer ten gronde voeren, private schadevergoedingsacties niet tegenhouden. De (beperkte, restrictief toegepaste) mogelijkheid voor ondernemingen om bij de Commissie of een NCA een reductie te bepleiten van een kartelboete die het voortbestaan van de onderneming in het gedrang zou brengen, geldt uiteraard evenmin voor schadevergoedingen die de onderneming eventueel in combinatie met de boetes zou moeten betalen. Dit zijn allemaal elementen die derhalve in het strategisch beslissingsproces over publieke afdwinging moeten worden meegenomen.

43. Elders hebben we de belangrijkste juridische vraagstukken naar Belgisch recht toegelicht. Het betreft de vraag naar fout (inbreuk op een specifieke rechtsnorm versus algemene zorgvuldigheidsnorm), schade (volledige vergoeding van zekere schade, vormen van schade bij schending van mededingingsregels, problematiek van het passing-on verweer), oorzakelijk verband (equivalentieleer), persoonlijk belang en collectieve vorderingen, en bewijs van de inbreuk en toegang tot het bewijsmateriaal. ${ }^{132}$

44. Wat het eerste element betreft, kan een onrechtmatig handelen naar Belgisch recht bestaan in de schending van een specifieke rechtsnorm (dat is een norm van nationaal recht of van een internationaal verdrag met rechtstreekse werking in de interne rechtsorde, waarbij een persoon verplicht is niets te doen of op een bepaalde manier wel iets te doen) of een inbreuk op de rechtens opgelegde zorgvuldigheidsnorm die een normaal, zorgvuldig en omzichtig persoon in de samenleving in acht moet nemen. Belangrijk verschil tussen beide vormen van onrechtmatig handelen is dat de schending van een specifieke rechtsnorm op zichzelf onrechtmatig is (behoudens onoverkomelijke dwaling of een andere rechtvaardigingsgrond zoals force majeure, zelfverdediging of noodtoestand ${ }^{\mathrm{1} 33}$ ) zonder dat moet worden nagegaan of de inbreukmaker uit onvoorzichtigheid, nalatigheid of zorgeloosheid heeft gehandeld, en evenmin of hij de schade als gevolg van de overtreding van de rechtsnorm diende te voorzien. In dergelijk geval van schending van een specifieke rechtsnorm is de veroorzaakte schade voorzienbaar te achten, tot bewijs van het tegendeel. ${ }^{134}$

Over de vraag of de mededingingsregels, in het bijzonder de regels van het kartelrecht, wel of niet een specifieke rechtsnorm uitmaken, is de rechtsleer verdeeld.

Een meerderheidsopvatting wijst erop dat het Belgisch recht, in tegenstelling tot Nederland (en Duitsland), geen Schutznorm-theorie kent en dat in België integendeel, volgens vaststaande rechtspraak van het Hof van Cassatie, de leer geldt dat elke inbreuk op een wettelijke of reglementaire bepaling, wat ook het beschermingsoogmerk van die bepaling moge zijn, als fout in de zin van art. $1382-1383$ B.W. (onrechtmatige daad) te kwalificeren valt. ${ }^{135}$ In dat geval is er, althans wat het materieel element betreft, van een fout sprake. De rechtspraak vereist ook een moreel element, de toerekenbaarheid van de handeling aan de persoon die wordt aangesproken.

I32 T. Schoors, T. Baeyens en W. Devroe, 'Schadevergoedingsacties na kartelinbreuken', NJW 20II, p. I98-2I3.

I33 Cass., I6 september 2005, C.04.0276.F, Pas. 2005, p. I663-I669.

I34 Deze en de volgende (korte) paragraaf zijn nauwelijks gewijzigd maar met weglating van voetnoten overgenomen uit T. Schoors T. Baeyens en W. Devroe, l.c., 20I-202, randnrs. I4-I5.

I35 Zie W. Van Gerven en S. Covemaeker, Verbintenissenrecht, Leuven: Acco 200I, p. 240. 
Een gezaghebbende minderheidsopvatting gaat niet akkoord met het automatisme waarmee een wetsinbreuk een fout zou uitmaken. ${ }^{136}$ Volgens deze auteurs kan een inbreuk op een wettelijke bepaling, zoals een kartelbepaling, slechts dan een fout in de zin van de art. $\mathrm{I}_{3} 82-\mathrm{I}_{3} 83 \mathrm{~B}$.W. opleveren wanneer een normaal voorzichtig en redelijk persoon die in dezelfde omstandigheden zou worden geplaatst er zich van bewust zou geweest zijn dat de handeling in kwestie verboden is.

Helaas ontbreekt rechtspraak die zich over deze aangelegenheid uitdrukkelijk uitspreekt.

Private afdwinging naar toekomstig recht

45. De Commissie maakt er geen geheim van dat ze private afdwinging van mededingingsrecht in de Unie wenst te bevorderen. Opvallend is bijvoorbeeld dat persberichten waarin de Commissie beboeting van een kartel aankondigt, tegenwoordig steevast eindigen met een uitnodiging aan benadeelde partijen om het vooral niet bij de boete te laten maar om daarbovenop ook nog een schadevergoedingsactie te starten:

\begin{abstract}
'Schadeclaims
Particulieren of ondernemingen die van concurrentiebeperkende praktijken zoals in deze zaak te lijden hebben, kunnen de zaak voor de nationale rechter brengen en schadevergoeding eisen. Zowel de rechtspraak van de EU-rechter als Verordening (EG) nr. I/2003 bevestigen dat een besluit van de Commissie voor de nationale rechter als bindend bewijsmateriaal kan worden gebruikt dat de praktijken hebben plaatsgevonden en verboden waren. Zelfs indien de Commissie de betrokken ondernemingen geldboeten heeft opgelegd, kunnen toch schadevergoedingen worden toegekend zonder dat deze hoeven te worden verlaagd omdat de Commissie al een geldboete heeft opgelegd. De Commissie vindt dat schadeclaims die een goede slaagkans maken, moeten inzetten op een billijke compensatie van de geleden schade voor de slachtoffers van een inbreuk. Over schadeclaims in antitrustzaken is een witboek gepubliceerd (zie [...]). Meer informatie over het witboek, met onder meer een publiekssamenvatting, is te vinden onder: [...] Voor meer informatie over de strijd van de Commissie tegen kartels, zie [...].'
\end{abstract}

46. Het denken over EU-recht omtrent private afdwinging is in een stroomversnelling gekomen sinds het Hof van Justitie in $200 \mathrm{I}$ het arrest Courage/Crehan ${ }^{137}$ wees, en daar in 2006 aan toevoegde dat slachtoffers van schendingen van de mededingingsregels recht hebben op volledige compensatie van de door hen geleden schade. ${ }^{13^{8}}$

I36 H. Gilliams-L. Cornelis, o.c., p. I7-I8.

I37 HvJ EG 20 september 200I, Courage Ltd./Bernard Crehan, supra, voetnoot 27, r.o. 26-27.

I38 Arrest van het Hof van Justitie van I3 juli 2006, gevoegde zaken C-295/04-C-298/04, Vincenzo Manfredi/Lloyd Adriatico Assicurazioni, Jurispr. 2006, p. I-66I9. 
47. De Commissie liet een studie uitvoeren, voorgesteld in 2004, waaruit moest blijken dat private afdwinging in Europa 'totaal onderontwikkeld' was. ${ }^{139}$ De studie identificeerde allerlei obstakels die schadevergoedingsacties wegens schending van de mededingingsregels bemoeilijken dan wel onmogelijk maken.

48. In december 2005 publiceerde de Commissie een Groenboek, ${ }^{\mathrm{I} 40}$ vergezeld van een uitgebreidere (maar niet vertaalde) Commission staff working paper. Ook volgens het Groenboek was het Europese ‘falen' op het gebied van private afdwinging grotendeels te wijten aan diverse juridische en procedurele hinderpalen. Sommige pistes die de Commissie lanceerde in het Groenboek waren bepaald ingrijpend, zelfs radicaal, zoals de introductie van double damages naar het model van de bestaande treble damages in de VS, of nog de introductie van class actions, discovery fasen tijdens schadevergoedingsprocedures enzovoort. Veel van de voorstellen leken geïnspireerd door wat nu al bestaat in (sommige) common law jurisdicties - met alle gevaren vandien voor de aantasting van de homogeniteit van het aansprakelijkheidsrecht in andere jurisdicties.

49. Aangemoedigd door het Europees Parlement (het Parlement) publiceerde de Commissie in april 2008 een Witboek betreffende schadevergoedingsacties wegens schending van de mededingingsregels van de Unie ${ }^{\text {I4I }}$ (het Witboek) voor openbare raadpleging, wederom vergezeld van een werkdocument van de diensten van de Commissie en een effectenbeoordeling. ${ }^{\mathrm{I} 2}$ De Commissie blijft bij het standpunt dat 'schadevergoedingsacties wegens schending van de mededingingsregels [een aantal specifieke kenmerken vertonen] waarmee onvoldoende rekening wordt gehouden in de klassieke regels inzake civiele aansprakelijkheid en de procedurevoorschriften'. ${ }^{143}$ Niettemin komen sommige van de meest ingrijpende maatregelen uit het Groenboek, zoals de mogelijkheid van double damages, niet meer voor in het Witboek. Andere voorgestelde maatregelen lijken genuanceerder. Bijzondere aandacht werd besteed aan de mogelijkheid en de modaliteiten van collectieve schadevergoedingsacties en de regels rond toegang tot bewijsmateriaal. Civielrechtelijk kregen het foutvereiste en de omvang van de schadevergoeding veel aandacht. Daarnaast poneerde de Commissie drie duidelijke beginselen: (a) volledige compensatie, (b) voorstellen van evenwichtige maatregelen die zijn geworteld in de Europese rechtscultuur en -tradities, en (c) het behoud van een daadkrachtige publieke afdwinging

I39 Study on the conditions of claims for damages in case of infringement of EC competition rules, II.

I40 Groenboek - Schadevorderingen wegens schending van de communautaire antitrustregels van ig december 2005 (doc. COM(2005)672) en Commission Staff working paper van I9 december 2005 (doc. SEC(2005)I732).

I4I Witboek betreffende schadevergoedingsacties wegens schending van de communautaire mededingingsregels van 2 april 2008 (doc. COM(2008)r65def., hierna 'Witboek').

I42 White Paper on Damages actions for breach of the EC antitrust rules, Commission staff working paper van 2 april 2008 (doc. SEC(2008)404).

I43 Hoofddoelstelling blijft dan ook om 'voor slachtoffers de juridische voorwaarden te verbeteren voor de uitoefening van het hun door het Verdrag verleende recht op herstel van alle schade die zij hebben geleden door een schending van de communautaire mededingingsregels': Witboek, p. 2-3. 
van de mededingingsregels waarbij de private afdwinging een aanvulling moet zijn. ${ }^{\mathrm{I} 4}$

50. Na opnieuw een openbare raadpleging (tot I5 juli 2008) werkten de Commissiediensten een ontwerprichtlijn uit om schadevergoedingsacties wegens schending van de art. IOI en I02 VWEU te vergemakkelijken (de Ontwerp Richtlijn). De tekst is echter nooit publiek gemaakt. Na protest van het Parlement, dat een veel nauwere betrokkenheid eiste bij de uitwerking van de tekst, besloot de nieuwe Europese commissaris bevoegd voor mededinging tot uitstel. Recent is een nieuwe publieke consultatie gelanceerd, waarvan de resultaten in de zomer van 201 I mogen worden verwacht.

\section{§ 6 Staatssteun}

5I. Bij het recht inzake steunmaatregelen is de taak van de nationale rechter beperkter dan bij het kartelrecht. Dit komt doordat art. I07 VWEU geen rechtstreekse werking heeft aangezien de Europese Commissie over een ruime marge beschikt om deze bepaling toe te passen en met name exclusief bevoegd is om de uitzonderingen van art. I07 lid 3 VWEU toe te passen.

Bovendien betreffen de regels inzake steunmaatregelen de relaties tussen lidstaten en ondernemingen. Een beroep op die regels door een onderneming tegen een andere onderneming ligt daarom niet voor de hand.

52. Toch is het niet uitgesloten dat een onderneming die concurreert met een onderneming die in strijd met het Verdrag steun heeft ontvangen zich op het Verdrag beroept om deze steunverlening aan te vechten. De eerste en laatste zin van art. Io8 lid 3 VWEU hebben immers wel rechtstreekse werking. Volgens de eerste zin wordt de Commissie van elk voornemen tot invoering of wijziging van steunmaatregelen tijdig op de hoogte gebracht. De laatste zin van die bepaling stelt dat zolang de Commissie geen uitspraak heeft gedaan de aangemelde steun niet ten uitvoer mag worden gelegd. Ook een nationale rechter kan dus de schending van de aanmeldingsplicht en van de schorsingsverplichting derhalve vaststellen.

53. Ten slotte zal de Commissie wanneer ze vaststelt dat uitgekeerde steun onverenigbaar is met de interne markt - dat wil zeggen, in strijd is met de materiële staatssteunbepaling uit het Verdrag, art. I07 VWEU - de lidstaat (moeten) verplichten de ten onrechte uitgekeerde steun van de begunstigde terug te vorderen. ${ }^{145}$ De Commissie kan een lidstaat eveneens tot terugvordering verplichten wanneer ze vaststelt dat steun illegaal (onrechtmatig) is, dat wil zeggen is uitgekeerd met miskenning van de procedurele staatssteunbepaling van art. no8 VWEU, en meer bepaald in strijd met de aanmeldings- of schorsingsverplichting.

I44 Zie voor een gedetailleerder bespreking van de evoluties vanaf de Verordening I/2003 tot en met het Witboek en het Werkdocument (maar niet van de evoluties sindsdien) E.J. Zippro, Privaatrechtelijke handhaving van mededingingsrecht (diss. Leiden), Deventer: Kluwer 2009, p. I67-I88.

I45 Zie art. I4 Verordening (EG) nr. 659/I999 van de Raad van 22 maart I999 tot vaststelling van nadere bepalingen voor de toepassing van artikel 93 van het EG-Verdrag, Pb. L 83/I, 27 maart 1999. 
Bij betwistingen over terugvordering is de nationale rechter bevoegd. Dergelijke betwistingen zijn relatief frequent, zeker in België stelt men recent een toename van het aantal zaken vast.

We bespreken hierna kort enkele van de markantste zaken.

54. Zaken over het Fonds voor de gezondheid en de productie van Dieren. In een arrest van 5 december 2008 in de zaak Belgische Staat/Slachthuis Swaegers deed het Hof van Cassatie ${ }^{\mathrm{I} 46}$ uitspraak in volgend, lang aanslepend, geding.

Een koninklijk besluit (K.B.) van II december 1987 legde met ingang van I januari I988 aan slachthuizen en uitvoerders van vlees per geslacht of levend uitgevoerd rund, kalf of varken een verplichte bijdrage op aan een 'Fonds voor de Gezondheid en de Productie van de Dieren'. In een beschikking van $199 I^{\mathrm{I}}{ }^{47}$ oordeelde de Commissie dat deze regeling, die niet bij haar was aangemeld, met de interne markt onverenigbare staatssteun uitmaakte voor zover de verplichte bijdragen ook over uit andere lidstaten ingevoerde dieren en producten werden geheven. België heeft vervolgens een ontwerp van nieuwe regeling uitgewerkt met als wezenlijk verschil dat voor ingevoerde dieren geen bijdragen meer zouden worden geheven en dat de bijdragen voor uitgevoerde dieren vanaf $\mathrm{I}$ januari 1997 niet meer verschuldigd zouden zijn. Deze ontwerpregeling heeft de Commissie in 1996 verenigbaar verklaard met de interne markt. ${ }^{148}$ Een 'reparatiewet' van 23 maart 1998 hief vervolgens - meer dan tien jaar later dus - het K.B. van II december 1987 op en voerde de daarin verplichte bijdragen met retroactieve kracht in vanaf $\mathrm{I}$ januari 1988 .

Over die beschikking gaat een prejudicieel arrest van het Hof van Justitie, in de zaak Van Calster e.a. ${ }^{\text {I99 }}$ Van Calster e.a. kochten en verkochten vee waarvan een deel werd uigevoerd. Ze hebben op basis van het K.B. van 1987 bijdragen betaald aan het Fonds. Kort gezegd betwistten ze voor de Belgische rechter de terugwerkende kracht van de heffing zoals ingevoerd door de reparatiewet van 1998. De Belgische rechter vroeg het Hof van Justitie (a) of art. Io8 lid 3 VWEU in de weg staat aan de heffing van bijdragen die weliswaar specifiek dienen ter financiering van een door de Commissie met de interne markt verenigbaar verklaarde steunregeling, maar die met terugwerkende kracht zijn opgelegd voor een periode voorafgaand aan de Commissiebeschikking en (b) of de Commissiebeschikking van 1996 een goedkeuring inhield van de terugwerkende kracht van de wet van 1998. Het Hof beantwoordde de eerste vraag bevestigend en de tweede ontkennend.

In het licht van dit antwoord verwierp het Hof van Beroep te Antwerpen de door de Belgische Staat ingestelde tegenvordering tot betaling van achterstallige bijdragen voor de periode vanaf 30 juli 1996 tot 30 april 1998 verworpen. Hiertegen voorzag de

I46 Cass. 5 december 2008, Belgische Staat/Slachthuis Swaegers, (C.07.0I45.n/I), Pas. 2008, p. 28462854, TBP 2009, p. 546-547.

I47 Beschikking 9I/538/EEG van de Commissie van 7 mei I99I betreffende het Belgische Fonds voor de gezondheid en de productie van de dieren, Pb. L 294/43, 25 oktober I99I.

I48 Beschikking van de Commissie van 9 augustus 1996 inzake steunmaatregel nr. N 366/96, niet gepubliceerd in het Publicatieblad.

I49 HvJ EG 2I oktober 2003, Belgische Staat/Eugene Van Calster en Felix Cleeren en Belgische Staat/ Openbaar Slachthuis NV, gevoegde zaken C-26I/oI en C-262/oI, Jurispr. 2003, p. I-I 2249. 
Staat zich in cassatie, met succes. Volgens het Hof van Cassatie schendt het arrest van het Hof van Beroep art. 108 lid 3 VWEU omdat het gebrek aan terugwerkende kracht van de Commissiebeschikking betekent dat enkel de vóór de datum van die Commissiebeschikking geheven bijdragen onrechtmatig zijn.

In de zaak Pierre Marx e.a. ${ }^{150}$ naar aanleiding van gelijkaardige navorderingen oordeelde het Hof van Beroep te Brussel dat de terzake geldende verjaringstermijn van vijf jaar de effectieve terugvordering van onrechtmatige steun niet praktisch onmogelijk maakt en dus moet worden toegepast. Bijgevolg oordeelde het Hof van Beroep dat de door de veehandelaren ingestelde vordering tot terugvordering van de ten onrechte betaalde bijdragen verjaard was. In Alcan had het Hof van Justitie geoordeeld dat de terugvordering in principe moet gebeuren overeenkomstig de bepalingen van nationaal recht, maar dat deze bepalingen de terugvordering niet praktisch onmogelijk mogen maken (een toepassing van het beginsel van procedurele autonomie, zie supra, randnr. I7). ${ }^{151}$

55. Maribel-zaken. Het bekende Maribel-dossier ${ }^{152}$ gaf aanleiding tot heel wat betwistingen naar aanleiding van de door de Commissie aan België opgelegde terugvorderingsplicht. ${ }^{153}$ Maribel voerde maatregelen in om de competitiviteit en tewerkstelling van Belgische ondernemingen te vrijwaren door een verlaging van de sociale bijdragen voor handarbeiders. De eerste maatregelen werden genomen in I98I, verdere verlagingen vonden plaats in 1993 (Maribel bis) en 1994 (Maribel ter). De maatregelen werden niet bij de Europese Commissie aangemeld. In I996 stelde de Commissie in een beschikking vast dat Maribel bis en ter met de interne markt onverenigbare steun uitmaakten. Omdat België de beschikking niet uitvoerde, bracht de Commissie België in 1998 voor het Hof van Justitie. Het Hof veroordeelde België in 200I. ${ }^{54} \mathrm{Na}$ verschillende jaren van moeizame onderhandelingen over de voorwaarden van terugvordering van de onrechtmatig uitgekeerde steun sloten de Belgische regering en de Commissie in april 1999 een protocolakkoord. Een programmawet van 24 december $1999^{155}$ stelde, ter uitvoering van dit akkoord, een kader vast voor de terugvordering. De Rijksdienst voor Sociale Zekerheid (RSZ) begon in 2000 met de terugvorderingen.

Een eerste zaak waarin de terugvordering werd betwist is die van Bis Rob Montagebedrijf. Dit bedrijf had tussen 1993 en 1997 van de vermindering van de sociale bijdragen genoten. Het stelde voor de rechter dat de Staat nalatig was geweest door de steun pas in 2000 terug te vorderen terwijl zij reeds in 1993 op de hoogte was van het risico dat de steun onverenigbaar zou worden verklaard en de terugvordering ervan zou worden bevolen. Het montagebedrijf verweet de Staat een schending van

I50 Brussel 27 april 2009, 2008/AR/I094, beschikbaar via www.juridat.be.

I5I HvJ EG 20 maart 1997, Land Rheinland Pfalz en Alcan/Commissie, C-24/95, Jurispr. I997, p. I-I5I9, r.o. 24 .

I52 Model of Analysis for Rapid Investigation of the Belgian Economy.

I53 Zie J. Derenne en M. Smeets, "Chronique "Aides d'Etat", Application des règles sur les aides d'Etat dans des affaires concernant la Belgique (juridictions belges et européennes, Commission européene). Années 2009 et 20I0', Tijdschrift voor Belgisch Mededingingsrecht $201 \mathrm{I}$, p. Ioo e.v.

I54 HvJ EG 3 juli 200I, Commissie/België, C-378/98, Jurispr. 200I, p. I-2I07.

I55 Wet houdende sociale en diverse bepalingen, B.S. 3I december I999. 
het Unierecht en van de algemene zorgvuldigheidplicht van art. $\mathrm{I}_{3} 82$ B.W. en vorderde schadevergoeding. De rechtbank van eerste aanleg te Dendermonde en, na hoger beroep, het Hof van Beroep te Gent, verwierpen de vordering op grond van de overweging dat een nationale norm geen afbreuk kan doen aan de effectieve toepassing van Unierecht. In haar voorziening in cassatie stelde de onderneming vervolgens dat zij nooit de voorrang van het Unierecht had betwist, maar dat die voorrang niet betekent dat de begunstigde van steun geen vordering tot vergoeding van andere schade zou kunnen instellen dan de loutere terugbetaling van de steun of het verlies van de onrechtmatige steun. De voorziening stoelde op de nalatigheid van de Staat. België zou de art. I07 en Io8 VWEU hebben geschonden door de waarschuwingen van de Commissie in de wind te hebben geslagen, de steun niet bij de Commissie te hebben aangemeld en door het creëren van een rechtmatige verwachting bij de begunstigden door pas in 2000 met de terugvordering te starten. Door die nalatigheid had het bedrijf een onjuiste prijs aangerekend aan zijn afnemers en dit kon het thans niet meer ongedaan maken. Het Hof van Cassatie volgde de voorziening en verbrak het arrest van het Hof van Beroep. ${ }^{156}$ Het oordeelde dat het Hof van beroep niet had geantwoord op het argument dat 'de fout van de overheid niet bestond in het terugvorderen van de onrechtmatige steun als dusdanig maar in het geheel van de onzorgvuldigheden en nalatigheden van de overheid'. Het Hof van Cassatie aanvaardt dus de mogelijkheid dat de begunstigde van onrechtmatige steun die geconfronteerd wordt met een vordering tot terugbetaling van die steun vanwege de Staat, vergoeding vordert van schade die onderscheiden kan worden van de schade die het gevolg is van de terugvordering.

Derenne en Smeets ${ }^{157}$ merken terecht op dat indien het bedrag dat de begunstigde uiteindelijk uit hoofde van een dergelijke vordering tot schadevergoeding zou kunnen eisen, gelijk is aan het teruggevorderde steunbedrag, de door het Hof van Cassatie gelaten mogelijkheid niet aanvaardbaar is vanuit een oogpunt van effectiviteit van Unierecht. Meer fundamenteel kan men zich afvragen hoe de volgens het Hof van Cassatie principieel mogelijke vordering tot schadevergoeding iets anders kan betekenen dan het de facto (deels) ongedaan maken van de terugvordering. De problemen die hierbij rijzen kunnen misschien voor een stuk worden vergeleken met de in ons recht goed bekende en vaak omschreven problemen bij samenloop tussen de vordering ex contractu en de vordering ex delicto. ${ }^{158}$ Volgens het Hof van Cassatie is de buitencontractuele vordering tegen de medecontractant mogelijk 'indien de hem ten laste gelegde fout een tekortkoming uitmaakt niet alleen aan de contractuele verbintenis maar ook aan de algemene zorgvuldigheidplicht die op hem rust

I56 Cass. I7 september 2009, Bis Rob Montagebedrijf t. Belgische Staat (C.08.0450.N.), zoals vermeld door J. Derenne en M. Smeets, l.c., p. Ior en voetnoot I2.

I57 J. Derenne en M. Smeets, l.c., p. I02.

I58 Voor een bespreking verwijzen we kortheidshalve naar J. Stuyck, 'Derden contractbreuk, samenloop en vordering tot staking', T.B.H. 2009, p. 932 e.v. Zie ook de door Derenne en Smeets, l.c., p. I03, kort besproken Franse rechtspraak waarin het probleem van het bewijs van het causaal verband centraal staat. 
en indien deze fout anders dan door de slechte uitvoering te wijten schade heeft veroorzaakt.'159

56. Maribel leidde ook tot het arrest Plastuni van het Arbeidshof van Brussel van 3 juni 20I0. ${ }^{160}$ De zaak betrof een andere bij de terugvordering van steun prangende vraag: kan de Staat de steun terugvorderen van de onderneming die inmiddels de begunstigde onderneming heeft overgenomen?

Plastuni had tussen 1993 en 1997 van Maribel verminderingen genoten. In uitvoering van het protocolakkoord waarvan hierboven sprake, werd in de Maribel-wet van I98I door de vermelde programmawet van 1999 een nieuw art. 37bis ingelast naar luid waarvan bij herstructurering of een algemene inbreng van activa in de zin van het vennootschapsrecht de terugvordering gebeurt van de nieuwe verkrijger in zijn hoedanigheid van werkgever. Plastuni komt in moeilijkheden en sluit een herstructureringsakkoord met een andere vennootschap. Plastuni wordt vereffend, bepaalde activa worden ingebracht in een nieuwe vennootschap Plastuni Operations. Er wordt overeengekomen dat slechts een deel van de schulden wordt overgedragen. De RSZ vordert van Palstuni Operations de Maribel-steun terug maar die onderneming betwist dat ze onderworpen is aan genoemd art. 37bis. Op basis van het protocolakkoord zou enkel een onderneming die het geheel van de schulden van de begunstigde onderneming heeft overgenomen tot terugbetaling kunnen worden veroordeeld. De RSZ beriep zich onder meer op de voorrang van het Unierecht om deze stelling te weerleggen. Het arbeidshof heeft, onder verwijzing naar constante rechtspraak van het Hof van Justitie, de RSZ gevolgd wat het principe betreft namelijk dat de terugvordering erop gericht moet zijn de situatie te herstellen die bestond vóór steunuitkering en dat dit vereist dat de steun wordt teruggevorderd van de effectieve begunstigde. In casu wees het arbeidshof de vordering van de RSZ tegen Plastuni Operations echter af. De effectieve begunstigde in dit geval was volgens het arbeidshof immers de verkoper en niet de verwerver van Plastuni Operations. Wanneer de begunstigde onderneming aan de marktprijs wordt verworven - en het arbeidshof liet experts bevestigen dat dit effectief het geval was geweest - bestaat er immers een vermoeden dat de steun aan de marktprijs werd geëvalueerd en begrepen is in de overnameprijs. In dergelijke omstandigheden kan de koper niet geacht worden begunstigde van de steun te zijn. Terugvordering van de werkelijke begunstigde, de verkoper, was in dit geval echter evenmin mogelijk omdat Plastuni vereffend was en elke activiteit op de markt had stopgezet. Derenne en Smeets merken op dat deze uitspraak conform is aan een mededeling van de Commissie uit 2007. ${ }^{16 \mathrm{I}}$

I59 Cass. 29 september 2006, R.W. 2006-2007, I7I2, noot A. Van Oevelen.

I60 J. Derenne en M. Smeets, l.c., p. I04, in voetnoot 2I verwijzen naar annotaties van het arrest maar niet naar een publicatie.

I6I Bekendmaking van de Commissie 'Naar een doelmatige tenuitvoerlegging van beschikkingen van de Commissie waarbij lidstaten wordt gelast onrechtmatige en onverenigbare steun terug te vorderen', $\mathrm{Pb}$. C 272/4, I5 november 2007, punt 6I. 


\section{§7 Vrijverkeerbepalingen}

\section{I Ruim toepassingsgebied van vrijverkeerbepalingen. Ook regels van privaatrecht kunnen (potentieel) het vrij verkeer belemmeren}

57. Zoals bekend, heeft het Hof van Justitie aan art. 34 VWEU sinds het arrest Dassonville $^{162}$ een ruime draagwijdte gegeven. Veel later gaf het Hof ook aan art. 35 VWEU (uitvoerbeperking) een ruime draagwijdte. ${ }^{\text {I63 }}$ In het arrest Keck en Mithouard ${ }^{164}$ beperkte het Hof de draagwijdte van Dassonville door nationale regels inzake verkoopmodaliteiten uit het toepassingsgebied van art. 34 VWEU te houden voor zover zij ingevoerde producten niet de jure of de facto discrimineren.

De huidige stand van de rechtspraak wordt weergegeven in het arrest Mickelsson en Roos: ${ }^{165}$

“[A]ls "maatregelen van gelijke werking als kwantitatieve invoerbeperkingen" in de zin van artikel [34 VWEU] moeten worden beschouwd, [i] de maatregelen van een lidstaat die ertoe strekken of tot gevolg hebben dat uit andere lidstaten afkomstige producten minder gunstig worden behandeld, alsook [ii] belemmeringen van het vrije goederenverkeer, die, bij ontbreken van harmonisatie van de nationale wettelijke regelingen, voortvloeien uit de toepassing op goederen uit andere lidstaten, waar zij rechtmatig zijn vervaardigd en in de handel gebracht, van voorschriften betreffende de voorwaarden waaraan die goederen moeten voldoen, ook indien die voorschriften zonder onderscheid op alle producten van toepassing zijn (...). Valt eveneens onder dit begrip, [iii] elke andere maatregel die de toegang tot de markt van een lidstaat voor uit andere lidstaten afkomstige producten belemmert (...).'

Deze laatste toevoeging is nieuw.

58. Al met al hebben de verdragsbepalingen over vrij goederenverkeer - de andere vrijheden komen verder aan bod - dus een ruim toepassingsgebied. De art. 34 en 35 VWEU zijn niet enkel van toepassing op voorschriften die rechtstreeks verband houden met de voorwaarden waaraan producten moeten voldoen.

59. Maatregelen van gelijke werking in de zin van art. 34 of 35 kunnen worden gerechtvaardigd op een van de gronden genoemd in art. 36 VWEU (o.a. openbare orde, goede zeden, bescherming van de volksgezondheid en de intellectuele eigendom) of, ten minste wanneer ze niet formeel discrimineren tussen binnenlandse handel enerzijds en import c.q. export anderzijds, op andere gronden van algemeen belang zoals de bescherming van de consument (de zogenoemde 'rule of reason' uit

I62 HvJ EG II juni I974, Procureur des Konings/Benoît en Gustave Dassonville, 8/74, Jurispr. I974, p. 837.

I63 HvJ EG I6 december 2008, Lodewijk Gysbrechts/Santurel Inter BVBA, C-205/07, Jurispr. 2008, p. I-9947.

I64 HvJ EG 24 november I993, Keck \& Mithouard, gevoegde zaken, C-267/9I en C-268/9I, Jurispr. I993, p. I-6097.

I65 HvJ EG 4 juni 2009, Mickelsson \& Roos, C-I42/05, Jurispr. 2009, p. I-4273. Geciteerd wordt hierna r.o. 24 . 
het arrest Cassis de $\left.\operatorname{Dijon}^{166}\right)$. De maatregel moet noodzakelijk zijn voor het bereiken van het doel van algemeen belang, wat een proportionaliteitstoets inhoudt.

6o. Ook regels van privaatrecht (contractrecht) kunnen potentieel het vrij verkeer belemmeren. Het Hof van Justitie heeft zich tot nu toe evenwel eerder terughoudend opgesteld bij het van toepassing verklaren van de bepalingen inzake vrij verkeer op regels van privaat recht. In dit verband kan worden verwezen naar drie arresten van het Hof van Justitie: Krantz, Alshtom Atlantique en Motorradcenter.

Het arrest Krantz betrof een Nederlandse regel van insolventierecht, volgens welke de ontvanger der directe belastingen beslag kan leggen op goederen waarop een beding van eigendomsvoorbehoud weegt. Het Hof oordeelde dat art. 34 VWEU zich niet tegen een dergelijke regel verzet wanneer de goederen afkomstig zijn en eigendom zijn van een leverancier uit een andere lidstaat. Het Hof overwoog daarbij dat de nationale bepaling zonder onderscheid van toepassing is op binnenlandse en ingevoerde goederen en niet tot doel heeft het handelsverkeer met de andere lidstaten te regelen. De mogelijkheid dat onderdanen van andere lidstaten minder geneigd zullen zijn goederen op afbetaling te verkopen aan kopers in de betrokken lidstaat, omdat de ontvanger beslag op die goederen zou kunnen leggen indien de kopers hun belastingschulden in Nederland niet betalen, is voorts zo onzeker en indirect, dat men van een nationale bepaling die dat beslag mogelijk maakt, niet kan zeggen dat zij de handel tussen de lidstaten belemmert. ${ }^{167}$

De twee andere arresten gaan meer specifiek over bepalingen van kooprecht. Alsthom Atlantique ${ }^{\mathrm{I} 68}$ betrof een exportsituatie, waarop het Hof de toen nog restrictieve rechtspraak van het Groenveld-arrest ${ }^{169}$ toepaste. In Groenveld oordeelde het Hof dat art. 36 VWEU enkel ziet op maatregelen die specifiek het uitgaand goederenverkeer betreffen. In Gysbrechts ${ }^{170}$ verruimde het Hof het toepassingsgebied van art. 35 VWEU tot maatregelen die niet discrimineren tussen uitvoerhandel en binnenlandse handel. Niet-discriminerende belemmeringen voor het exportverkeer moeten voortaan dus ook kunnen worden gerechtvaardigd op grond van ofwel de uitdrukkelijke verdragsuitzonderingen van art. 36 VWEU ofwel de 'rule of reason'. Alsthom betrof de vraag naar de verenigbaarheid van art. 1643 van de Code Civil (vrijwaring voor verborgen gebreken), een bepaling die aldus wordt geïnterpreteerd dat zij een onweerlegbaar vermoeden bevat dat de professionele verkoper de verborgen gebreken kende tenzij de koper een in die goederen gespecialiseerde professionele koper is. Het Hof merkt op dat deze regeling, voortvloeiend uit de rechtspraak van de Cour de Cassation, zonder onderscheid van toepassing is op alle commerciële

I66 HvJ EG 20 februari 1979, Rewe-Zentral AG/Bundesmonopolverwaltung für Branntwein, I20/78, Jurispr. I979, 649 .

I67 HvJ EG 7 maart I990, H. Krantz GmbH \& Co./Ontvanger der Directe Belastingen en Staat der Nederlanden, 69/88, Jurispr. I990, p. I-583. Zie r.o. Io en II.

I68 HvJ EG 24 januari I99I, Alsthom Atlantique SA/Compagnie de construction mécanique Sulzer SA, C-339/89, Jurispr. I99I, p. I-I07.

I69 HvJ EG 8 november I979, P.B. Groenveld BV/Produktschap voor Vee en Vlees, I5/79, Jurispr. I979, p. 3409 .

I70 Supra, voetnoot 162. 
relaties die door Frans recht worden beheerst en noch als voorwerp noch als effect heeft de uitvoerhandel te beperken en de nationale handel te bevoordelen.

Duidelijker en nog steeds actueel is het arrest Motorradcenter. ${ }^{171}$ Het Hof van Justitie werd gevraagd of art. 34 VWEU zich verzet tegen een verplichting, naar Duits recht, voor een importeur om de koper (van een Yamaha-motorfiets) ervan op de hoogte te brengen dat de door Yamaha erkende officiële verdelers voor motoren die parallel zijn ingevoerd vaak weigeren om herstellingen onder garantie uit te voeren. Naar Duits recht bestaat er vanaf het begin van contractuele onderhandelingen een vertrouwensrelatie tussen partijen. Volgens vaste rechtspraak, aldus het Hof van Justitie, vloeit uit deze vertrouwensrelatie een informatieplicht voort in die zin, dat elke partij verplicht is de andere partij attent te maken op haar bekende omstandigheden die doorslaggevend zijn voor de beslissing van de andere partij, ook al houden die omstandigheden geen verband met het voorwerp van de koop of de hoedanigheden ervan. De importeur riskeerde schadeplichtig te zijn uit hoofde van 'culpa in contrahendo'. Het Hof verwijst naar Dassonville: iedere regeling die de intracommunautaire handel al dan niet rechtstreeks, daadwerkelijk of potentieel kan belemmeren, is een maatregel van gelijke werking. Het Hof overweegt evenwel het volgende:

'Io. In casu moet in de eerste plaats erop worden gewezen, dat de door het Duitse verbintenissenrecht opgelegde precontractuele informatieplicht, althans t.a.v. uit de gemeenschap afkomstige producten, zonder onderscheid van toepassing is op alle door dat recht beheerste contractuele verhoudingen en niet tot doel heeft, het handelsverkeer te regelen.

II. Wat betreft de vraag, of het vrije verkeer van goederen gevaar loopt te worden belemmerd, is het in ieder geval niet de informatieplicht die dit gevaar zou doen ontstaan, maar veeleer de weigering van bepaalde dealers van het betrokken merk om onder de garantie vallende reparaties aan parallel geïmporteerde motorfietsen uit te voeren.'

6r. Voor België is deze uitspraak eveneens van belang. Volgens art. 4 van de wet van 6 april 2or betreffende marktpraktijken en consumentenbescherming ${ }^{172}$ moet een onderneming, ten laatste op het ogenblik van het sluiten van de overeenkomst, te goeder trouw aan de consument de behoorlijke en nuttige informatie geven over de belangrijkste kenmerken van het product en over de verkoopsvoorwaarden, rekening houdend met de door de consument uitgedrukte behoefte aan informatie en het door de consument meegedeelde of redelijkerwijze voorzienbare gebruik. Het soort informatie waarvan in Motorradcenter sprake was, valt mogelijk onder 'behoorlijke en nuttige informatie betreffende de verkoopsvoorwaarden'.

Meer in het algemeen zou een wettelijke precontractuele informatieplicht zoals die van art. 4 van de wet van 6 april 2orI wel een effect kunnen hebben op het vrije verkeer van goederen, men denke aan grensoverschrijdende verkoop op afstand. In deze situatie geldt evenwel binnenkort een geharmoniseerde precontractuele

I7I HvJ EG 24 februari I994, Motorradcenter, C-93/92, Jurispr. I993, p. I-5009.

I72 B.S., I2 april 2010. 
informatieplicht. ${ }^{173}$ Toch zal de verenigbaarheid van (dwingende) regels van verbintenissenrecht met de vrije verkeersbepalingen van geval tot geval moeten worden beoordeeld. In dit verband volstaat het te verwijzen naar de eerder genoemde zaak Gysbrechts. ${ }^{174}$ In deze zaak oordeelde het Hof van Justitie dat de (inmiddels opgeheven) bepaling uit de Belgische wet handelspraktijken (uit I99I) die een leverancier verbiedt bij (ondermeer grensoverschrijdende) verkoop op afstand voor het verstrijken van de herroepingstermijn een voorschot of een betaling te vragen aan de consument en hem verbiedt vóór het verstrijken van die termijn het nummer van de betaalkaart van de consument te vragen (als garantie) belemmeringen zijn in de zin van art. 35 VWEU. Het Hof toetste deze belemmeringen aan de 'rule of reason' en vond dat het verbod betaling te vragen wel gerechtvaardigd was maar het verbod het nummer van de betaalkaart te vragen dat niet was.

62. De arresten Krantz, Alshtom Atlantique en Motorradcenter zijn ouder dan Keck en Mithouard. Het blijft evenwel onzeker of de uitsluiting van niet discriminerende nationale bepalingen inzake verkoopmodaliteiten uit het toepassingsgebied van art. 34 VWEU, kan worden toegepast op regels van verbintenissen- en contractenrecht. Het gaat immers niet om modaliteiten, of voorwaarden waaronder producten in het verkeer kunnen worden gebracht. De band met het vrij goederenverkeer is mogelijk nog minder direct, zoals overigens ook blijkt uit de overwegingen van het Hof in deze drie zaken.

Uit de drie arresten kan evenwel worden onthouden dat het verband tussen een regel van verbintenissenrecht en de belemmering van het vrij goederenverkeer doorgaans te weinig rechtstreeks zal zijn. Men mag dus aannemen dat, zelfs dwingende, regels van privaatrecht, inzonderheid van verbintenissenrecht en contractenrecht, normaal niet onder het toepassingsgebied van de art. 34 en 35 VWEU zullen vallen.

63. Met betrekking tot de andere internemarktvrijheden, het vrij verkeer van personen, diensten en kapitaal, kan het volgende worden opgemerkt.

Zoals bekend, geldt een 'convergentie van vrijheden': het Hof heeft zijn Cassis de Dijon-rechtspraak inzake art. 34 (en recent ook 35) VWEU uitgebreid naar de andere vrijheden. Die vrijheden zien dus eveneens op belemmeringen die niet discrimineren tussen binnenlandse en grensoverschrijdende situaties, en die gerechtvaardigd kunnen worden uit hoofde van een door het Unierecht erkend algemeen belang (zoals bescherming van de consument, het milieu, de beleggers, de cultuur). De latere Keck- (en Mickelsson en Roos-) rechtspraak kent evenwel zijn gelijke niet op het gebied van de andere vrijheden. ${ }^{175} \mathrm{Er}$ is ook geen rechtspraak bekend waar het Hof als zodanig bepalingen van zuiver privaatrecht (dat verhoudingen tussen particulieren regelt) inhoudelijk toetst aan die andere vrijheden.

I73 Zie artikel 6 van de nieuwe richtlijn inzake consumentenrechten (zoals aangenomen in het EP op 23 juni 20II; Wetgevingsresolutie van het Europees Parlement van 23 juni 20 II over het voorstel voor een richtlijn van het Europees Parlement en de Raad betreffende consumentenrechten (COM(2008)o6r4-C6-0349/2008-2008/0196(COD)).

I74 Supra, voetnoot 162 .

I75 Zie samenvattend HvJ EG 30 november 1995, R. Gebhard/Consiglio dell' Ordine degli Avvocati e Procuratori di Milano, C-55/94, Jurispr. I995, p. I-4I86. 
Met betrekking tot het recht van vestiging en de vrijheid van dienstverlening kan wel worden verwezen naar de hierboven aangehaalde rechtspraak over reglementen van sportorganisaties (inzonderheid het arrest Walrave) waar het Hof deze verdragsvrijheden van toepassing acht op door privéorganisaties uitgevaardigde regels die arbeid in loondienst en zelfstandige arbeid op collectieve wijze regelen (supra, 2.I; in Viking en Laval werden deze vrijheden toegepast op feitelijke acties van vakbonden en niet op privaatrechtelijke regels of afspraken, supra, 2.3).

Wat betreft het vrij kapitaalverkeer ten slotte is de 'gouden aandeel (golden share)'rechtspraak van het Hof relevant. ${ }^{176}$ Deze kwalificeert wettelijke regelingen in de lidstaten die aan de overheid in gemengde ondernemingen vetorechten toekennen als (doorgaans niet, maar in het geval van België wel, gerechtvaardigde) belemmeringen voor het vrij kapitaalverkeer. In het arrest Commissie/Duitsland van 23 oktober $2007^{177}$ over de zogenoemde 'Volkswagen'-wet verwierp het Hof het argument van de Bondsrepubliek dat art. 63 VWEU niet van toepassing was omdat de bestreden wettelijke regeling berustte op een in 1959 tussen individuen en groepen gesloten privaatrechtelijke overeenkomst. Het Hof overwoog dat zelfs indien dit het geval zou zijn, het volstond dat die overeenkomst het voorwerp was geworden van de wet om ze als nationale maatregel te beschouwen voor de toepassing van art. 63 VWEU. Het Hof deed dus geen uitspraak over de mogelijke toepasselijkheid van art. 63 VWEU op een privaatrechtelijke regeling.

\subsection{Niet afdwingbaarheid van publiekrechtelijke normen in privérelaties}

64. In het arrest CIA Security ${ }^{178}$ diende het Hof zich voor de eerste keer uit te spreken over de rechtsgevolgen van de schending door een lidstaat van de verplichting om, conform Richtlijn 83/189/EEG ${ }^{179}$ en in het kader van het vrij verkeer van goederen, elk nieuw technisch voorschrift vóór invoering aan de Commissie mee te delen. Opnieuw (zie hierboven over de z- en Haacht II-zaken over nietigheid van art. Ior lid 2 VWEU) ging de prejudiciële vraag uit van de rechtbank van koophandel te Luik. De vraag was gerezen in het kader van een vordering tot staking wegens een oneerlijke handelspraktijk (met name het op de markt brengen van alarmsystemen en alarmcentrales die niet in overeenstemming waren met een nationaal technisch voorschrift). De verweerder in het geschil beriep zich op strijdigheid van het nationale voorschrift met de richtlijn. Hoewel het een geschil tussen particulieren betrof, aanvaardde het Hof een beroep op de richtlijn. Nu het wettelijk technisch voorschrift niet aan de Commissie was meegedeeld, kon het niet aan particulieren worden tegengeworpen. Het gaat dus niet om 'subjectieve' horizontale rechtstreekse

I76 HvJ EG 4 juni 2002, Commissie/Portugal, C-367/98, Jurispr. 2002, p. I-473I; HvJ EG 4 juni 2002, Commissie/Frankrijk, C-483/99, Jurispr. 2002, p. I-478I; HvJ EG 4 juni 2002, Commissie/België, C-503/99, Jurispr. 2002, p. I-4809.

I77 HvJ EG 23 oktober 2007, Commissie/Bondsrepubliek Duitsland, C-II2/05, Jurispr. 2007, p. I-8995.

I78 Supra, voetnoot 50. In Nederland wordt dit arrest merkwaardigerwijs meestal 'Securitel'-arrest genoemd.

I79 Richtlijn 83/I89/EEG van de Raad van 28 maart I983 betreffende een informatieprocedure op het gebied van normen en technische voorschriften, $\mathrm{Pb}$. L Iog/8, 26 april 1983 . 
werking (supra, randnr. I2), maar om de onmogelijkheid, zij het n.a.v. een vordering van een particulier, om een technisch voorschrift dat in strijd is met (een procedurebepaling van) een richtlijn tegen een particulier in te roepen. Het Hof besliste dat de meldingsplicht van de richtlijn aldus moet worden uitgelegd dat particulieren zich daarop kunnen beroepen voor de nationale rechter (ook, zoals in casu, tegen een andere particulier). Die rechter moet een nationaal voorschrift dat niet overeenkomstig de richtlijn is meegedeeld, buiten toepassing laten. Hoe de rechter dit doet is dan weer een vraag van nationaal recht (zie hierna).

65. In het arrest Unilever ${ }^{180}$ stelde het Hof uitdrukkelijk dat de nationale rechter in het kader van een burgerlijke procedure tussen particulieren betreffende contractuele rechten en verplichtingen moet weigeren om een nationaal technisch voorschrift toe te passen dat is vastgesteld tijdens een periode van uitstel bedoeld in art. $9^{\mathrm{I} 8 \mathrm{I}} \mathrm{van}$ Richtlijn 83/189/EEG.

66. In het arrest Sapod Audic ${ }^{182}$ ging het Hof een stapje verder. Het Hof maakte vooreerst duidelijk dat de verplichting van de nationale rechter om een niet bij de Commissie aangemeld nationaal technisch voorschrift buiten toepassing te laten, ook van toepassing is wanneer partijen naar een dergelijke reglementering verwijzen in een contract dat ze vrijwillig hebben aangegaan. Vervolgens stelde het Hof:

'dat naar nationaal recht moet worden bepaald welke conclusie in de hoofdzaak voortvloeit uit de niet-toepasselijkheid van [de nationale bepaling] inzake de strekking van de ingevolge het toepasselijke nationale recht daaraan verbonden gevolgen, zoals de nietigheid of de niet-tegenwerpbaarheid van de overeenkomst [...], met name wat de contractrechtelijke regels en beginselen betreft die deze gevolgen naar evenredigheid van de aard van het vastgestelde gebrek beperken of aanpassen. Deze regels en beginselen mogen evenwel niet ongunstiger zijn dan die voor vergelijkbare vorderingen op basis van nationaal recht (gelijkwaardigheidsbeginsel) en mogen de uitoefening van de door de communautaire rechtsorde verleende rechten in de praktijk niet onmogelijk maken (effectiviteitsbeginsel).'

Onder verwijzing naar Rewe ${ }^{183}$ past het Hof aldus de tweevoudige test toe bekend uit de rechtspraak over procedurele autonomie.

I80 HvJ EG 26 september 2000, Unilever Italia SpA / Central Food SpA, supra, voetnoot 90.

I8I Volgens lid I van art. 9 'stellen de Lid-Staten de goedkeuring van een ontwerp van technisch voorschrift zes maanden uit [...] indien de Commissie of een andere Lid-Staat binnen een termijn van drie maanden na die datum de uitvoerig gemotiveerde mening te kennen geeft, dat de beoogde maatregel moet worden gewijzigd ten einde eventuele belemmeringen voor het vrije verkeer van goederen die uit die maatregel kunnen voortvloeien op te heffen of te beperken.' In bepaalde omstandigheden kan de periode van uitstel tot I2 maanden worden verlengd. Lid 3 bevat een uitzondering indien een lidstaat 'om dringende redenen die verband houden met de bescherming van de volksgezondheid of de veiligheid in zeer korte tijd technische voorschriften moet uitwerken en ze onmiddellijk daarop moet vaststellen en zonder uitstel moet invoeren, zonder dat enige raadpleging mogelijk is'.

I82 HvJ EG 6 juni 2002, Sapod Audic/Eco-Emballages SA, supra, voetnoot $5 \mathrm{I}$.

I83 Met verwijzing naar HvJ EG I6 december I976, Rewe, 33/76, Jurispr. I976, p. I989. 


\subsection{Vrij verkeer en onrechtmatige daad}

67. Over de mogelijkheid om particulieren die inbreuk plegen op Verdragsbepalingen aansprakelijk te stellen voor vergoeding van de schade die zij door die inbreuk aan andere particulieren hebben berokkend, zijn zowel de uitspraak van de Zweedse arbeidsrechtbank die volgde op het arrest van het Hof van Justitie in de Laval-zaak, als de commentaar daarop van Bernitz en Reich verhelderend. ${ }^{84}$

68. Men zal zich herinneren (supra, 2.3) dat de Zweedse vakbond, volgens het Hof van Justitie in strijd met de bepalingen inzake vrij verkeer, een collectieve actie had gevoerd tegen Laval wegens sociale dumping. De Zweedse arbeidsrechtbank veroordeelde de vakbond tot schadevergoeding ten gunste van Laval en baseerde deze veroordeling rechtstreeks op de schending van art. 56 VWEU. Volgens de rechtbank houdt de vrijheid van dienstverlening de mogelijkheid in voor een privéonderneming om zich daarop tegen een vakbond te beroepen (zoals het Hof had beslist), inclusief het recht om schadevergoeding te vorderen. Volgens de rechtbank houdt deze verdragsbepaling dus een recht op schadevergoeding in tussen particulieren. De nationale rechtbank verwees daartoe onder meer naar Courage en Manfredi (die, zoals hierboven aangegeven betrekking hebben op schendingen van de mededingingsregels) en, meer in het bijzonder naar Racanelli. ${ }^{185}$

Andrea Raccanelli was een Italiaanse doctoraal kandidaat die op basis van haar nationaliteit economisch gediscrimineerd werd door een privéonderzoeksorganisatie. Het Hof overwoog:

'52. Onder deze omstandigheden moet (...) worden geantwoord dat, indien verzoeker in het hoofdgeding zich terecht heeft beroepen op een nadeel dat is veroorzaakt door tegen hem gerichte discriminatie, het aan de verwijzende rechter staat om in het licht van de nationale wetgeving op het gebied van niet-contractuele aansprakelijkheid te beslissen over de aard van de vergoeding waarop verzoeker in het hoofdgeding aanspraak kan maken.'

In Laval stelde de Zweedse rechtbank vast dat er in de rechtspraak van het Hof geen unierechtelijke grondslag te vinden was voor een recht op schadevergoeding bij schending van art. 56 VWEU, maar leidde uit genoemde arresten wel af dat die rechtspraak een algemeen beginsel van Unierecht had ontwikkeld volgens hetwelk het toekennen van schadevergoeding mogelijk moet zijn tussen particulieren bij schending van een verdragsbepaling die horizontale rechtstreekse werking heeft.

Vervolgens stelde de arbeidsrechtbank vast dat het Unierecht geen specifieke regels inzake procedure of onrechtmatige daad bevat die in een dergelijk geval kan worden toegepast. Ook naar Zweeds recht zijn er geen bepalingen die in een dergelijke situatie rechtstreeks toepasselijk zijn. Bijgevolg, zo vervolgt de arbeidsrechtbank, moet

I84 Arbetsdomstolen 2 december 2009 (A 268/04), Laval un Partneri Ltd v. Svenska Byggnadsarbetarförbundet et al., noot U. Bernitz en N. Reich, C.M.L.Rev., 20II, p. 603 e.v.

I85 HvJ EG I7 juli I7 juli 2008, Andrea Raccanelli/Max-Planck-Gesellschaft zur Förderung der Wissenschaften eV., C-94/07, Jurispr. 2008, p. I-5939. 
zij, na conflicterend Zweeds recht terzijde te hebben geschoven of te hebben gereconstrueerd, het type vergoeding bepalen dat Laval kan eisen. De vergoeding moet adequaat zijn, ze moet de schade volledig vergoeden en ze mag, gelet op het equivalentiebeginsel, niet discrimineren tegen vorderingen die gesteund zijn op schendingen van EU-recht in vergelijking met vorderingen die gesteund zijn op schendingen van nationaal recht.

Uiteindelijk kende de rechtbank enkel 'exemplary damages' toe (ten bedrage van 60.000 euro) omdat Laval niet in staat was gebleken economisch verlies te bewijzen.

69. Volgens Bernitz en Reich is de nationale uitspraak het resultaat van wat zij een 'hybridisatie' van verhaalmiddelen (of hybride verhaalmiddelen) noemen. In casu is er een vordering tot schadevergoeding die haar grondslag (Anspruchsgrundlage) heeft in nationaal recht, maar hertekend en opgewaardeerd wordt onder de invloed van EU-recht.

Bernitz en Reich gaan ook in op het vereiste van een voldoende gekwalificeerde inbreuk, zoals vereist in de rechtspraak van het Hof, zowel inzake aansprakelijkheid van lidstaten en ondernemingen bij schendingen van Unierecht als bij de niet-contractuele aansprakelijkheid van de instellingen. Enkel wanneer een administratie een beperkte of geen marge van discretie heeft (of waar een richtlijn geen ruimte laat voor interpretatie) kan een loutere schending van unierecht een voldoende gekwalificeerde schending opleveren. Dergelijke gedetailleerde vereisten kunnen, zo merken de auteurs terecht op, moeilijk worden toegepast op privéactoren, zoals vakbonden (in Viking en Laval) of sportorganisaties (zoals in Walrave en Bosman). Voor dergelijke organisaties pleiten de auteurs ervoor dat zij enkel tot schadevergoeding zouden veroordeeld worden wanneer de schending voldoende duidelijk is, in die zin dat het beginsel van EU-recht al voldoende moet gevestigd zijn en dat de betrokkene redelijkerwijze niet kon denken dat zijn handeling gerechtvaardigd was naar beginselen van EU-recht. Aldus rijst ook de vraag naar de situatie waar de Staat een gedraging van particulieren uitsluit uit het toepassingsgebied van de regels inzake mededinging of vrij verkeer. Kan de gedraging van een onderneming, beroepsvereniging of vakbond die zich op de uitsluiting beroept dan nog wel geacht worden een voldoende duidelijke schending uit te maken? De auteurs pleiten ervoor om exoneratie uit te sluiten wanneer de schending van het EU-recht (zoals in Laval) voldoende manifest is.

70. In de lijn van dit laatste punt kan een andere, voor België prangende vraag worden gesteld. Zoals bekend, hebben vakbonden naar Belgisch recht geen rechtspersoonlijkheid. Tegen hen kan dus ook geen vordering tot schadevergoeding worden ingesteld wegens onrechtmatige daad bij het voeren van syndicale acties. Zou het in het licht van het bovenstaande echter niet zo kunnen of moeten zijn dat, indien Belgische vakbonden een collectieve actie zouden voeren die kennelijk in strijd is met de vrijverkeerbepalingen (zoals door het Hof geïnterpreteerd in Viking en Laval), de slachtoffers van het onrechtmatig handelen niettemin, op basis van het nationale aansprakelijkheidsrecht zoals geherinterpreteerd in het licht van de beginselen die uit de rechtspraak van het Hof af te leiden vallen en teneinde het 'effet utile' van de vrije verkeersbepalingen te verzekeren, schadevergoeding zouden kunnen vorderen? 


\section{§ 8 (Andere) Verdragsbepalingen inzake discriminatie}

\section{I Het gelijkheidsbeginsel in het primair unierecht}

7I. Het gelijkheidsbeginsel is een van de belangrijkste verwezenlijkingen van de moderne rechtsstaat, mede dankzij de evolutie van het EU-recht.

Het oorspronkelijke EEG-Verdrag (art. 6) bevatte reeds een verbod van discriminatie op grond van nationaliteit als fundamenteel beginsel, en dit teneinde de gemeenschappelijke markt (nu interne markt) te realiseren. Dit verbod is nu terug te vinden in art. I8 VWEU en wordt verder geconcretiseerd in de bepalingen over vrij verkeer die hierboven aan bod kwamen.

Om te vermijden dat werkgevers uit lidstaten waar het beginsel van gelijk loon voor gelijk werk voor mannen en vrouwen reeds gold bij de inwerkingtreding van het EEG-Verdrag (zoals Frankrijk) een concurrentienadeel zouden ondervinden op de interne markt werd ook dit beginsel opgenomen, in art. IIg EEG (zie thans art. I57 VWEU).

Afgezien van enkele zeer specifieke niet-discriminatiebepalingen in de hoofdstukken over het gemeenschappelijk landbouwbeleid en het gemeenschappelijk vervoerbeleid, bekommerde het Verdrag zich verder niet over gelijke behandeling.

72. Het Hof van Justitie oordeelde echter reeds op basis van het oorspronkelijke EEG-Verdrag dat het gemeenschapsrecht (nu Unierecht) een algemeen discriminatieverbod bevat. Het Hof leidde dit af uit art. 34, lid 2, EG-Verdrag (nu art. 40, lid 2, VWEU) naar luid waarvan de gemeenschappelijke ordening der landbouwmarkten 'elke discriminatie tussen producenten of verbruikers' van de Unie moet uitsluiten. Het Hof overwoog dat het in dat artikel vervatte discriminatieverbod slechts een bijzondere uitdrukking is van het algemene gelijkheidsbeginsel dat een der grondprincipes van het Unierecht is, en dat krachtens dit beginsel gelijke omstandigheden niet verschillend mogen worden behandeld, tenzij dat verschil objectief gerechtvaardigd is. ${ }^{186}$

73. Thans is het gelijkheidsbeginsel niet meer alleen een algemeen (ongeschreven) beginsel van Unierecht. Het heeft een verdragsrechtelijke basis gekregen. Het is neergelegd in het Handvest van de grondrechten van de Europese Unie (art. 20: iedereen is gelijk voor de wet) en is bovendien een van de 'waarden' waarop de Unie is gebaseerd (art. 2 VEU). Een belangrijke doelstelling van de Unie is overigens de bestrijding van discriminatie en het streven naar het opheffen van de ongelijkheid tussen mannen en vrouwen (art. 3, lid 3, VEU). Het Handvest verbiedt (in art. 2I) elke discriminatie op grond van geslacht, ras, kleur, etnische of sociale oorsprong, genetische kenmerken, taal, religie of geloof, politieke of andere overtuiging, lidmaatschap van een minderheid, eigendom, geboorte, handicap, leeftijd of seksuele geaardheid en herneemt (art. 2I, lid 2) het verbod van discriminatie op grond van nationaliteit.

I86 HvJ EG I9 oktober I977, Albert Ruckdeschel \& Co. en Hansa-Lagerhaus Ströh \& Co./Hauptzollamt Hamburg-St. Annen (en andere zaak), II7/76 en I6/77, Jurispr. 1977, p. 1753, r.o. 7; zie ook K. Lenaerts en P. Van Nuffel, Europees Recht, Antwerpen: Intersentia 20II, p. Io9. 
74. Zeer vroeg heeft het Hof van Justitie, naar aanleiding van een prejudiciële vraag door een Belgische rechter, aan het discriminatieverbod van het huidige art. I57 VWEU individuele horizontale rechtstreeks werking verleend. ${ }^{187}$ Een werknemer kan er zich in een individuele arbeidsrelatie dus op beroepen tegen zijn of haar werkgever. Later erkende het Hof ook de individuele horizontale rechtstreekse werking van het verbod van discriminatie(op grond van nationaliteit) in art. 45 VWEU (vrij verkeer van werknemers). ${ }^{\mathrm{I} 8}$ Ten slotte achtte het Hof art. 49 VWEU (recht van vestiging) en art. 49 VWEU (vrijheid van dienstverlening) eveneens toepasselijk op collectieve acties of regelingen van bepaalde niet-gouvernementele organisaties, zoals sportfederaties ${ }^{189}$ en vakbonden..$^{190}$

Deze discriminatieverboden grijpen dus rechtstreeks in privaatrechtelijke verhoudingen in.

75. Recente uitspraken van Belgische rechters over art. I8 of $157 \mathrm{VWEU}$ zijn er voor zover ons bekend niet, maar het EU-non-discriminatierecht bestaat tegenwoordig vooral uit richtlijnen.

\subsection{Non-discriminatierichtlijnen}

76. Thans gelden: Richtlijn 76/207/EEG over gelijke behandeling mannen en vrouwen in het arbeidsproces en wat betreft de arbeidsvoorwaarden (ter aanvulling van art. I57 VWEU over gelijke beloning), ${ }^{191}$ Richtlijn 2000/78/EG 'tot instelling van een algemeen kader voor gelijke behandeling in arbeid en beroep' (bestrijding van discriminatie op grond van godsdienst of overtuiging, handicap, leeftijd of seksuele geaardheid), ${ }^{192}$ Richtlijn 2000/43/EG 'houdende toepassing van het beginsel van gelijke behandeling van personen ongeacht ras of etnische afstamming ${ }^{{ }^{193}}$ en Richtlijn 2004/II3/EG 'houdende toepassing van het beginsel van gelijke behandeling van mannen en vrouwen bij de toegang tot en het aanbod van goederen en diensten'. ${ }^{194}$

77. De afgelopen jaren heeft het Hof van Justitie enkele arresten gewezen over deze richtlijnen die in onze pers veel aandacht hebben gekregen omdat ze betrekking hebben op belangrijke maatschappelijke problemen naar aanleiding van feiten die zich in België hebben voorgedaan.

I87 HvJ EG 8 april I976, Defrenne/Sabena II, supra, voetnoot 8 o.

I88 HvJ EG 6 juni 2000, Angonese/Cassa di Risparmio di Bolzano, supra, voetnoot 2.

I89 HvJ EG I2 december I974, Walrave en Koch/Wielerbonden, supra, voetnoot 23.

I9o HvJ EG II december 2007, ITWF/Viking, en HvJ EG I8 december 2007, Laval/Vakbonden, supra, voetnoot II.

I9I Richtlijn 76/207/EEG van de Raad van 9 februari 1976 betreffende de tenuitvoerlegging van het beginsel van gelijke behandeling van mannen en vrouwen ten aanzien van de toegang tot het arbeidsproces, de beroepsopleiding en de promotiekansen en ten aanzien van de arbeidsvoorwaarden, $\mathrm{Pb}$. L 39/40, I4 februari 1976.

I92 Richtlijn 2000/78/EG van de Raad van 27 november 2000, Pb. L 303/I6, 2 december 2000.

I93 Richtlijn 2000/43/EG van de Raad van 29 juni 2000, Pb. L I8o/22, I9 juli 2000; err. Pb. L I99/86, 5 augustus 2000.

I94 Richtlijn 2004/II3/EG van de Raad van I3 december 2004, Pb. L 373/37, 2I december 2004. 
78. Vooreerst is er het arrest Feryn ${ }^{195}$ over discriminatie op basis van ras. Het arrest interpreteert Richtlijn 2000/43/EG.

Het Centrum voor gelijkheid van kansen en voor racismebestrijding ageerde in kort geding voor de Voorzitter van de arbeidsrechtbank te Brussel tegen de publieke verklaringen van de directeur van een bedrijf dat garagepoorten installeert. De verklaringen van de directeur kwamen er in wezen op neer dat zijn onderneming monteurs wilde aanwerven, maar geen allochtonen in dienst kon nemen omdat de klanten er bezwaar tegen hadden om deze tijdens de werkzaamheden toegang te geven tot hun woning. De Voorzitter wees de vordering af, met name op grond dat niet was aangetoond, noch het vermoeden was aangebracht, dat iemand zich voor een betrekking had aangemeld en op grond van zijn etnische afstamming was afgewezen. In hoger beroep stelde het arbeidshof evenwel prejudiciële vragen aan het Hof van Justitie. Het arbeidshof vroeg met name of er sprake is van directe discriminatie in de zin van art. 2 lid 2 van Richtlijn 200/43/EG en of de omkering van de bewijslast van art. 8 lid I van die richtlijn moet worden toegepast op een situatie waarin onder verwijzing naar publieke uitlatingen van een werkgever over zijn aanwervingbeleid wordt gesteld dat dit beleid discriminerend is.

Het Hof van Justitie antwoordde tweemaal bevestigend. De werkgever dient dan te bewijzen dat het beginsel van gelijke behandeling niet is geschonden. Hij kan dit doen door aan te tonen dat de praktijk die de onderneming bij aanwerving in feite toepast, niet overeenstemt met de publieke verklaringen. Volgens het Hof staat het aan de verwijzende rechter om na te gaan of de beweerde feiten vaststaan en te beoordelen of de elementen die de werkgever aanvoert ten betoge dat hij het beginsel van gelijke behandeling niet heeft geschonden, toereikend zijn.

Op 28 augustus 2009 besliste het arbeidshof te Brussel ${ }^{196}$ dat er inderdaad sprake was van discriminatie. Na een aantal minder gewichtige verweermiddelen van Feryn van tafel te hebben geveegd antwoordde het arbeidshof op het centrale argument dat de onderneming handelde onder druk van klanten. Het arbeidshof wees ook dit argument af op grond van de overweging dat Feryn niet bewees dat de klanten geen allochtone monteurs willen - en, zo vraagt het hof zich af, onderschat Feryn het clienteel niet, in de mate dat dit ook beseft dat werk het belangrijkste is voor de integratie van eenieder in de maatschappij?

Het arbeidshof spreekt zich dus niet uit over de vraag of Feryn toereikende elementen had aangebracht voor de bewering dat het beginsel van gelijke behandeling niet geschonden was. Het oordeelt enkel dat Feryn de door hem aangevoerde feiten niet bewezen had. Op de vraag of de aangevoerde feiten indien ze wel bewezen waren het vermoeden van discriminatie zouden hebben kunnen ontkrachten, diende het arbeidshof dus niet in te gaan.

I95 HvJ EG Io juli 2008, Centrum voor gelijkheid van kansen en voor racismebestrijding/Firma Feryn NV, C-54/07, Jurispr. 2008, p. I-5187.

I96 Arbh. Brussel 28 augustus 2009 (KG 292), Soc.Kron. 2010, p. 260-265, noot. 
79. Een tweede arrest, Belgische Verbruikersunie Test-Aankoop, ${ }^{197}$ betreft Richtlijn 2004/113/EG. Het is een belangrijk arrest, niet alleen omdat het uitgesproken werd door de Grote kamer van het Hof maar ook en vooral omdat naar aanleiding van een prejudiciële vraag een bepaling uit een richtlijn ongeldig wordt verklaard, wat uitzonderlijk is.

Aan de basis lag een verzoek dat de verbruikersunie en een paar van haar leden bij het Grondwettelijk Hof hadden ingediend tot vernietiging van de wet van 2I december 2007 'tot wijziging van de wet van Io mei 2007 ter bestrijding van discriminatie tussen vrouwen en mannen wat betreft het geslacht in verzekeringsaangelegenheden', ${ }^{198}$ die toeliet om voortaan voor levensverzekeringen bij de bepaling van verzekeringspremies en -prestaties een proportioneel direct onderscheid te maken op grond van geslacht als dat bij de beoordeling van het risico op basis van relevante en nauwkeurige actuariële en statistische gegevens een bepalende factor blijkt. ${ }^{199}$ Aldus werd gebruik gemaakt, voor levensverzekeringen, van de mogelijkheid die art. 5 lid 2 van Richtlijn 2004/II3/EG aan de lidstaten biedt om proportionele verschillen in premies en uitkeringen voor individuele personen toe te staan in de gevallen waarin sekse een bepalende factor is bij de beoordeling van het risico op basis van relevante en nauwkeurige actuariële en statistische gegevens. De afwijking gold enkel voor levensverzekeringen, op basis van de sterftetabellen, maar niet voor andere verzekeringen zoals autoverzekeringen (terwijl uit alle beschikbare studies blijkt dat vrouwelijke chauffeurs minder ongevallen veroorzaken dan mannelijke).

Het Hof van Justitie oordeelde dat art. 5 lid 2 van Richtlijn 2004/II3/EG met ingang van 2I december 2012 ongeldig is. Volgens het Hof vereist de gelijke behandeling van vrouwen en mannen dat lidstaten niet (op blijvende wijze) afwijken van het principe van unisekspremies voor verzekeringen. Bij het aanbieden van goederen en diensten of bij het bepalen van contractsvoorwaarden mag geen onderscheid worden gemaakt op basis van ras of geslacht. Daarmee is de vraag nog niet beantwoord of het niet-discriminatieverbod naar omstandigheden een partij ook kan dwingen tot het sluiten van een contract met een persoon met wie hij geen ruiltransactie wenst aan te gaan.

8o. Het discriminatieverbod is ingrijpend. Ongelijke behandeling blijft weliswaar mogelijk indien levering van goederen en diensten aan (uitsluitend of hoofdzakelijk) leden van een bepaald geslacht door een legitiem doel wordt gerechtvaardigd en de middelen voor het bereiken van dat doel passend en noodzakelijk zijn. Bij verzekeringen echter kunnen, volgens het arrest Test Aankoop nooit verschillende premies worden aangerekend voor mannen en vrouwen, hoewel te argumenteren valt dat met verschillende premies in bepaalde gevallen beslist een legitiem doel wordt

I97 HvJ EU I maart 20II, Belgische Verbruikersunie Test-Aankoop VZW, Yann van Vugt, Charles Basselier/Ministerraad, nog niet gepubliceerd in de Jurisprudentie. In bepaalde lidstaten bestaan er (of bestonden er althans ten tijde van de uitspraak van het Hof van Justitie in deze zaak) verschillen op basis van geslacht bij andere soorten verzekeringen, zoals die inzake wettelijke aansprakelijkheid motorrijtuigen (WAM), arbeidsongevallen en arbeidsongeschiktheid. Zie Y. Thiery, Discriminatie en verzekering, Antwerpen: Intersentia 20II, 667-668, nr. 9I8.

I98 B.S., 3I december 2007.

I99 Art. Io wet 2I december 2007. 
nagestreefd en de verschillende premies voor het bereiken van dat doel passend en noodzakelijk zijn. ${ }^{200}$

Meer in het algemeen blijkt het steeds verder uitdeinend toepassingsgebied van het anti-discriminatierecht fundamenteel voor het privaatrecht. De horizontale werking van het gelijkheidsbeginsel transformeert in toenemende mate het privaatrecht in het algemeen en het contractenrecht in het bijzonder. Concepten als partijautonomie en contractvrijheid moeten constant worden herzien, niet enkel ter bescherming van de zwakke contractspartij (zoals de werknemer, de consument of de huurder) maar ook ter consecratie van grote idealen. Het is in dat verband betekenisvol dat de expertgroep voor een Europees contractenrecht ${ }^{201}$ in een van de eerste vergaderingen, bij de selectie van belangrijke onderwerpen voor de werkzaamheden, heeft besloten om geen rekening te houden met de doorwerking van grondrechten, zoals discriminatieverboden, in het contractenrecht.

\section{§ 9 (Andere) Algemene beginselen van Unierecht}

8I. Elders hebben we onze inzichten over de impact van algemene beginselen van Unierecht op nationaal privaatrecht uitvoerig toegelicht. ${ }^{202}$ Liever dan die bijna 57 pagina's tekst hier samen te vatten, wat tot weinig zeggende veralgemeningen dreigt te leiden, verwijzen we (a) naar wat elders in dit preadvies is geschreven over het beginsel van procedurele autonomie, het gelijkheidsbeginsel en de toepassing daarvan via vrijverkeerbepalingen en (b) naar de beschouwingen in het preadvies van A. Hartkamp over de Europeesrechtelijke aspecten. ${ }^{203}$

82. Helaas moeten ook wij vaststellen, dat ons geen voorbeelden bekend zijn waarin de Belgische rechter direct of indirect horizontale werking toekent aan algemene beginselen van Unierecht, al zijn die voorbeelden er allicht wel. We twijfelen evenmin aan de mogelijkheid voor de Belgische rechter om zulke werking toe te kennen en maken bij wijze van troostprijs toch melding van één geval waarin, bij wijze van alternatieve oplossing in een concreet rechtsgeschil, toepassing van een algemeen beginsel mogelijk en allicht zelfs verkieslijk ware geweest.

Samoy bespreekt een vonnis van de arbeidsrechtbank van Brussel van 2 december 2005. ${ }^{204}$ Een scheidsrechter vecht zijn ontslag door de Koninklijke Belgische Voetbalbond (KBVB) aan; volgens hem voert de KBVB een beleid van ontslag zodra de leeftijdsgrens van 45 jaar wordt bereikt. De bescherming die de hierboven besproken Richtlijnen 2000/43/EG en 2000/78/EG (supra, randnrs. 76-78) bieden tegen

200 Y. Thiery, o.c., p. 667-668, nr. 9I8.

201 Zie voor de opdracht, de werking en de resultaten van de expertgroep: A European Contract law for consumers and businesses: Publication of the results of the feasibility study carried out by the Expert Group on European Contract law for stakeholders' and legal practitioners' feedback, in mei 20 II gepubliceerd op de website van de Europese Commissie, DG Justice, www.ec.europa.eu/justice/contract/files/ feasibility-study_en.pdf, 93p.

202 W. Devroe, 'Impact van door het Europees Hof van Justitie ontwikkelde algemene beginselen op privaatrechtelijke verhoudingen', in: Hartkamp/Sieburgh/Keus I, supra, voetnoot 7, p. I33-I89.

203 Zie supra, randnr. I7, § 7.I, § 7.3, § 8.I en zie § 7.I-7.3 van het preadvies van A. Hartkamp.

204 I. Samoy, l.c. (supra, voetnoot 2), op p. I7. 
discriminatie op grond van leeftijd wordt ingeroepen. Ofschoon Richtlijn 2000/78/ EG nog niet in Belgisch recht moest zijn omgezet op het moment dat de feiten zich voordeden, maakt de arbeidsrechtbank er toch toepassing van, van oordeel dat op haar een plicht tot richtlijnconforme interpretatie rust (vgl. de rechtsvraag aan de orde in de zaak Spector, supra, randnr. I5). Samoy bekritiseert de gevolgde redenering 'omdat ... de verplichting tot richtlijnconforme interpretatie pas start bij het verstrijken van de omzettingstermijn van de Richtlijn'. ${ }^{205}$ In dit geval was het wellicht te verkiezen geweest dat de nationale rechter, minstens bijkomend, toepassing had gemaakt van het gelijkheidsbeginsel als algemeen beginsel van Unierecht - al zijn we ons bewust van de kritiek die op het arrest Mangold ${ }^{206}$ is geuit en de beperkende lezing ervan door het Hof van Justitie in latere zaken.

\section{§ io Ambtshalve toepassing}

\section{I0.I Openbare orde. Ambtshalve toepassing van art. Ior lid 2 VWEU}

83. Van de in nummer 8.2 van het preadvies van A. Hartkamp genoemde gronden voor een verplichting tot ambtshalve toepassing lijkt vooral de omstandigheid dat een regel van EU-recht van openbare orde is naar Belgisch recht van belang. In België wordt de ambtshalve toepassing van een wettelijke bepaling doorgaans immers gekoppeld aan het openbare-ordekarakter van die bepaling.

84. Of het Unierecht überhaupt het begrip openbare orde kent, is lang betwist geweest. ${ }^{207}$ In zijn preadvies wijst A. Hartkamp terecht op het arrest T-Mobile Netherland $5^{208}$ waarin het Gerecht oordeelt dat art. Ior VWEU een 'voor de vervulling van de taken van de Europese [Unie] onontbeerlijke bepaling van openbare orde is, die door de nationale rechter ambtshalve moet worden toegepast'. ${ }^{209}$ Opgemerkt zij dat het Hof van Justitie zich, voor zover ons bekend, tot nu toe nimmer in die zin heeft uitgesproken dat art. IOI VWEU, of enige andere bepaling van primair of secundair Unierecht, een openbaar ordekarakter draagt. Wel heeft het Hof herhaaldelijk geoordeeld dat de nationale rechter deze of gene bepaling van Unierecht ambtshalve moet toepassen (zie hierna).

85. Zoals in $\$ 5$ reeds aangegeven leidt schending van art. Ior lid I VWEU tot nietigheid van rechtswege van overeenkomsten en wordt naar Belgisch recht die nietigheid van art. Ior lid 2 VWEU geacht van openbare orde te zijn. Het lijdt geen twijfel dat de rechter, conform het arrest T-Mobile Netherlands, de nietigheid ambtshalve moet inroepen.

205 Ibid.

206 Supra, voetnoot 48.

207 Zie pro: T. Corthaut, EU Ordre Public (diss. Leuven) 2009, met talrijke verwijzingen naar de jurisprudentie van het Hof van Justitie.

208 HvJ EG 4 juni 2009, T-Mobile Netherlands e.a./Raad van bestuur van de Nederlandse Mededingingsautoriteit, C-8/08, Jurispr. 2009, p. I-4529.

209 Zie r.o. 49. 


\section{I0.2 Ambtshalve toepassing van richtlijnen}

86. Voor het belang van de discussie over de ambtshalve toepassing van richtlijnen in het kader van dit preadvies en voor een bespreking van de rechtspraak van het Hof van Justitie over Richtlijn 93/I3/EEG over oneerlijke bedingen ${ }^{210}$ verwijzen we naar het preadvies van A. Hartkamp. Met hem stellen we vast dat vooral na het arrest Pénzügyi ${ }^{211}$ de verplichting voor het ambtshalve optreden van de rechter bij onrechtmatige bedingen die ten nadele van de consument zijn, ver reikt. Wij zijn het met hem eens dat moet worden afgewacht of de verplichting om op zoek te gaan naar de feiten ter beantwoording van de vraag of het betwiste beding binnen de werkingsfeer van de richtlijn oneerlijke bedingen valt, alleen betrekking heeft op een forumkeuzebeding dan wel ook betrekking heeft op bedingen in contracten met consumenten het algemeen. Zoals hij ook opmerkt, kan er bij onrechtmatige bedingen geen sprake zijn van absolute nietigheid, laat staan van een regel van openbare orde. In België kan deze nietigheid enkel door de consument worden ingeroepen of, zoals blijkt uit de jurisprudentie van het Hof van Justitie en van het Hof van Cassatie (zie hierna), ten behoeve van de consument door de rechter. Een onderneming zal zich niet op de nietigheid kunnen beroepen en de consument kan uiteraard de geldigheid van een beding dat onrechtmatig is aanvaarden wanneer dat in zijn belang is. Dit blijkt uit de wettelijke regeling in België inzake onrechtmatige bedingen, met name uit art. 75 van de wet van 6 april 2010 betreffende marktpraktijken en consumentenbescherming. ${ }^{212}$ Artikel 75, §I, van die wet bepaalt dat elk onrechtmatig beding verboden en nietig is. De overeenkomst blijft bindend voor partijen indien ze zonder de onrechtmatige bedingen kan voortbestaan. De consument kan geen afstand doen van de rechten die hem bij deze afdeling worden toegekend. Dit laatste betekent dat de consument er zich niet geldig kan toe verbinden geen beroep te doen op de mogelijkheden die de wettelijke regeling inzake onrechtmatige bedingen hem verleent.

87. In België werd de vraag of de rechter ambtshalve de onrechtmatigheid van een beding kan vaststellen lange tijd beheerst door het onderscheid tussen absolute en relatieve nietigheid. Enkel bepalingen van openbare orde worden traditioneel met absolute nietigheid getroffen. Bij bepalingen van (zuiver) dwingend recht geldt de relatieve nietigheid. Er was met name onenigheid over de vraag of de wettelijke regeling inzake onrechtmatige bedingen van dwingend recht, dan wel van openbare orde was. ${ }^{213}$ Het onderscheid tussen nietigheid van dwingend recht en openbare orde

210 Richtlijn 93/I3/EEG van de Raad van 5 april 1993 betreffende oneerlijke bedingen in consumentenovereenkomsten, $\mathrm{Pb}$. L 95/29, 2I april 1993.

2 II HvJ EU 9 november 20I0, Pénzügyi, C-I37lo8, nog niet gepubliceerd in de Jurisprudentie.

2 I2 B.S. I2 april 20Io. Op de relevante punten is de wet van 6 april 2010 identiek aan de regeling uit de inmiddels opgeheven wet van I4 juli I99I betreffende de handelspraktijken, B.S. 29 augustus I99I.

2 I3 Zie P. Cambie, Onrechtmatige bedingen, Brussel: Larcier 2009, p. 425. J. Stuyck verdedigde de opvatting dat deze regeling van louter dwingend recht is aangezien bezwaarlijk kan worden aangenomen dat de bescherming van de consument iets anders beoogt dan de bescherming van private belangen (zie annotatie Océano Grupo, CMLRev. 200I, 73I-733). Voor de argumenten pro dwingend recht c.q. openbare orde, zie P. Cambie, o.c., p. 425-426. 
heeft een aantal rechtsgevolgen (inroepbaarheid, verjaring, werking in de tijd van een bepaling die met nietigheid wordt gesanctioneerd). Een ervan is, zoals gezegd, dat de rechter de nietigheid die van openbare orde is, ambtshalve moet inroepen, terwijl hij dit niet moet doen bij nietigheid die betrekking heeft op bepalingen van louter dwingend recht. Cambie ${ }^{214}$ merkt op dat dit onderscheid minder belangrijk is geworden sinds het Hof van Cassatie in $2005^{215}$ uitdrukkelijk heeft gesteld dat de rechter de verplichting heeft om ambtshalve de aandacht te vestigen op de rechtsmiddelen waarvan de toepassing volgt uit de door partijen aangevoerde feiten ter ondersteuning van hun vorderingen. Overigens heeft het Hof van Cassatie in een later arrest uit $2005^{216}$ gesteld dat de regeling inzake onrechtmatige bedingen in de wet vrije beroepen van dwingend recht is. Men mag aannemen dat dit ook geldt voor de gelijkaardige regeling inzake onrechtmatige bedingen in de Wet marktpraktijken.

Aldus is de Belgische rechtspraak thans in overeenstemming met de rechtspraak van het Hof van Justitie die de rechter, in elk geval bij forumkeuzebedingen, verplicht ambtshalve de onrechtmatigheid van het beding te onderzoeken en zo nodig vast te stellen. ${ }^{217}$

\section{S II Samenvatting}

88. In het algemeen blijkt de invloed van Europees recht, in het bijzonder EU-recht op het privaatrecht, sterk toegenomen. Dit is vooral het gevolg van een toegenomen activiteit van de Uniewetgever: richtlijnen en soms verordeningen die lidstaten dwingen hun regels van privaatrecht (consumentenrecht, vennootschapsrecht, arbeidsrecht, enz.) aan te passen. Toch grijpen ook de fundamentele verdragsvrijheden en algemene beginselen van Unierecht hoe langer hoe meer in private rechtsverhoudingen in.

De invloed van die ontwikkelingen op het Belgisch recht is nog moeilijk te duiden. Behalve op het gebied van het mededingingsrecht, waar het VWEU zelf in een civiele sanctie voorziet (de nietigheid van met art. IoI, lid I, strijdige overeenkomsten) is er weinig nationaal rechtspraak waaruit die invloed duidelijk blijkt. Wel zijn er een aantal interessante ontwikkelingen.

In de toekomst zal de invloed van het EU-recht op het Belgisch privaatrecht beslist nog fors toenemen. Men denke aan de recente opkomst van vorderingen tot schadevergoeding, de toenemende betwistingen voor nationale rechtbanken inzake terugvordering van onrechtmatige steun, de mogelijke toepassing van de vrije verkeersbepalingen op bijvoorbeeld vakbonden, die naar Belgisch recht tot nu toe over een soort immuniteit beschikken, het om zich heen grijpend Europees antidiscriminatierecht dat in toenemende mate private verhoudingen beïnvloedt, niet alleen

214 P. Cambie, o.c., p. 427.

215 Cass. I4 april 2005, J.T. 2005, 659, noot Van Compernolle; J.L.M.B. 2005, 856, noot G. De Leval.

2I6 Cass. 26 mei 2005, J.T. 2005, 609.

217 HvJ EG 27 juni 2000, Océano Grupo, supra, voetnoot 90. 
arbeidsverhoudingen maar ook verhoudingen tussen ondernemingen en consumenten. Last but not least bestaat op dit moment een reëel uitzicht op een embryo van Europees contractenrecht.

89. Bij de studie van de invloed van Europees recht op nationaal privaatrecht worden twee benaderingswijzen samen gehanteerd. In een eerste benadering worden gevallen opgelijst waarin toepassing wordt gemaakt van Europees recht binnen de privaatrechtelijke sfeer. Er kan dan een inventaris volgen van gevallen waarin instrumenten van privaatrecht door Europees recht zijn beïnvloed, allicht per rechtsdomein (handelsrecht, verzekeringsrecht, vennootschapsrecht enz.) en met illustraties in de vorm van bijvoorbeeld rechterlijke uitspraken of verboden clausules.

Een tweede benadering zoekt naar wijzen waarop Europees recht nationaal overeenkomsten- of aansprakelijkheidsrecht zelf meer dan marginaal beïnvloedt (en niet slechts individuele gevallen die daaronder ressorteren). Deze tweede benadering is niet meer op dezelfde wijze per rechtsdomein geordend, bestudeert veeleer technieken van doorwerking van Europees recht en is vanuit dat perspectief allicht meer geneigd om ook uit te kijken naar toekomstige rechtsontwikkelingen zoals eenmaking van contractenrecht, en EU-recht over private afdwinging van mededingingsrecht betoont bijzondere interesse voor:

- het aanreiken door EU-recht van nieuwe privaatrechtelijke optionele instrumenten;

- het niet optioneel maar dwingend invoeren door EU-recht van nieuwe generieke vormen van aansprakelijkheid of meer in het algemeen van nieuwe rechtsmiddelen;

- harmonisatie die aanvankelijk kon worden opgevat als 'minimum' harmonisatie maar waarvan het Hof van Justitie vervolgens beslist dat ze volledige harmonisatie beoogt;

- nog ingrijpender vormen van herschrijven van nationaal overeenkomstenrecht, aansprakelijkheidsrecht (of gerechtelijk recht ter afdwinging van dat overeenkomsten- of aansprakelijkheidsrecht), bijvoorbeeld onder invloed van een optioneel instrument inzake contractenrecht of een mogelijke richtlijn private afdwinging.

We spreken geen voorkeur uit voor de eerste of tweede benadering van onderzoek en kiezen, zoals de overige rechtsleer, ook niet exclusief voor het een of het ander. Om verwarring bij de studie van of het spreken over de invloed van Europees recht op nationaal privaatrecht te voorkomen, lijkt bewustzijn van het onderscheid ons echter nuttig.

90. Bij de studie van de invloed van primair EU-recht op nationaal privaatrecht kunnen het secundaire EU-recht en 'publiekrechtelijke' arresten niet volledig buiten beschouwing blijven. We illustreerden dit aan de hand van recente Belgische vonnissen en arresten in de zaken Spector, Citibank en VEBIC.

9I. Wie bepalingen schendt van kartelrecht loopt drie risico's: nietigheid van de overeenkomst, beboeting (publiekrechtelijke afdwinging die in dit preadvies niet ter sprake komt), en een schadevergoedingsactie (private afdwinging van mededingingsrecht). Europeesrechtelijk is de nietigheid van art. 101 lid 2 VWEU automatisch, 
verplicht en absoluut. Er is heel wat rechtspraak in België over de toepassing van deze nietigheidsanctie.

92. Opgang lijkt het fenomeen te maken dat wij 'ik dacht dat ik een contract met $\mathrm{u}$ had' noemen en dat hierin bestaat dat een contractpartij, hetzij uit oprechte bekommernis om naleving van EU-recht hetzij om minder nobele motieven, nietigheid wegens schending van art. Ior lid I VWEU inroept om aan contractuele verplichtingen een einde te stellen (te ontsnappen?).

93. Een potentieel veel grotere invloed op nationaal privaatrecht dan de loutere nietigheidssanctie van art. Ior lid 2 VWEU heeft de zogenoemde private afdwinging van mededingingsrecht. Deze gaat uit van particulieren (natuurlijke of rechtspersonen) die via de nationale rechtscolleges vonnissen en arresten afdwingen waarbij ter bescherming van hun private belangen schadevergoeding wordt toegekend. De in België sterk ontwikkelde praktijk van vorderingen tot staken zou eveneens als vorm van private afdwinging kunnen worden beschouwd maar in het algemeen geldt nu dat wanneer naar 'private afdwinging van mededingingsrecht' wordt verwezen, daar een aspect van vordering van schadevergoeding aan is verbonden.

Wat private afdwinging betreft, onderscheidt men best duidelijk tussen enerzijds de plannen van de Commissie over een mogelijke harmonisering van geldend nationaal recht, die dus nog niet tot geldend recht hebben geleid, en anderzijds de bestaande rechtspraktijk, waarin ook zonder EU-recht steeds meer schadevergoedingsacties worden ingesteld voor nationale rechtbanken. Over de vraag of de mededingingsregels, in het bijzonder de regels van het kartelrecht, naar geldend Belgisch recht wel of niet een specifieke rechtsnorm uitmaken waarvan schending op zichzelf onrechtmatig is, is de rechtsleer verdeeld.

94. Bij het recht inzake steunmaatregelen is de taak van de nationale rechter beperkter dan bij het kartelrecht. Toch zijn ook hier markante Belgische arresten te signaleren. Besproken zijn zaken over het 'Fonds voor de gezondheid en de productie van Dieren' en de zogenoemde Maribel-zaken.

95. Het Hof van Justitie heeft aan de EU-vrijuerkeerbepalingen een ruim toepassingsgebied toegekend. Ook regels van privaatrecht kunnen (potentieel) het vrij verkeer belemmeren. Het Hof blijkt eerder terughoudend in het rechtstreeks toetsten van regels van privaatrecht (onder meer contractenrecht) aan de verdragsvrijheden. Wel aanvaardt het Hof de toepassing van die vrijheden, althans de persoonsvrijheden, op regelingen en gedragingen van niet-gouvernementele organisaties.

In zijn rechtspraak over niet-afdwingbaarheid van publiekrechtelijke normen in privérelaties maakt het Hof duidelijk dat de verplichting van de nationale rechter om een niet bij de Commissie aangemeld nationaal technisch voorschrift buiten toepassing te laten, ook van toepassing is wanneer partijen naar een dergelijke reglementering verwijzen in een contract dat ze vrijwillig hebben aangegaan.

De rechtspraak van het Hof over de mogelijkheid om particulieren die inbreuk plegen op Verdragsbepalingen aansprakelijk te stellen voor vergoeding van de schade die zij door die inbreuk aan andere particulieren hebben berokkend, en de wijze waarop deze rechtspraak door de Zweedse nationale rechter na Laval is geïnterpreteerd, kan onvermoede gevolgen hebben voor het Belgische recht. 
96. Recente uitspraken van Belgische rechters over het gelijkheidsbeginsel in het primaire EU-recht (in het bijzonder art. I8 of I57 VWEU) zijn er voor zover ons bekend niet, maar het EU-non-discriminatierecht bestaat tegenwoordig vooral uit richtlijnen. Daarover heeft het Hof van Justitie recent arresten gewezen die in België veel aandacht hebben gekregen omdat ze betrekking hebben op belangrijke maatschappelijke problemen naar aanleiding van feiten die zich in België hebben voorgedaan (arrest Feryn, arrest Belgische Verbruikersunie Test-Aankoop).

Het steeds verder uitdeinend toepassingsgebied van het anti-discriminatierecht is fundamenteel voor het privaatrecht. De horizontale werking van het gelijkheidsbeginsel transformeert in toenemende mate het privaatrecht in het algemeen en het contractenrecht in het bijzonder. Concepten als privéautonomie en contractvrijheid moeten constant worden herzien.

97. We twijfelen niet aan de mogelijkheid voor de Belgische rechter om directe of indirecte horizontale werking toe te kennen aan algemene beginselen van Unierecht maar kennen geen recente Belgische rechtspraak hierover. Eén geval is besproken waarin, bij wijze van alternatieve oplossing in een concreet rechtsgeschil, toepassing van een algemeen beginsel mogelijk en allicht zelfs verkieslijk ware geweest.

98. Om te bepalen of de Belgische rechter een verplichting tot ambtshalve toepassing van EU-recht heeft, lijkt vooral de omstandigheid dat een regel van EU-recht van openbare orde is naar Belgisch recht van belang aangezien ambtshalve toepassing van een wettelijke bepaling in België doorgaans wordt gekoppeld aan het openbareordekarakter van die bepaling. 